\title{
Overview of Antagonists Used for Determining the Mechanisms of Action Employed by Potential Vasodilators with Their Suggested Signaling Pathways
}

\author{
Yean Chun Loh, Chu Shan Tan, Yung Sing Ch'ng, Mariam Ahmad, Mohd Zaini Asmawi and \\ Mun Fei Yam * \\ School of Pharmaceutical Sciences, Universiti Sains Malaysia, 11800 Minden, Penang, Malaysia; \\ nicklesloh@hotmail.com (Y.C.L.); weazley90@hotmail.com (C.S.T.); yungsing1003@hotmail.com (Y.S.C.); \\ mariam@usm.my (M.A.); amzaini@usm.my (M.Z.A.) \\ * Correspondence: yammunfei@yahoo.com; Tel.: +60-4-653-4586
}

Academic Editor: Derek J. McPhee

Received: 27 January 2016; Accepted: 28 March 2016; Published: 15 April 2016

\begin{abstract}
This paper is a review on the types of antagonists and the signaling mechanism pathways that have been used to determine the mechanisms of action employed for vasodilation by test compounds. Thus, we exhaustively reviewed and analyzed reports related to this topic published in PubMed between the years of 2010 till 2015. The aim of this paperis to suggest the most appropriate type of antagonists that correspond to receptors that would be involved during the mechanistic studies, as well as the latest signaling pathways trends that are being studied in order to determine the route(s) that atest compound employs for inducing vasodilation. The methods to perform the mechanism studies were included. Fundamentally, the affinity, specificity and selectivity of the antagonists to their receptors or enzymes were clearly elaborated as well as the solubility and reversibility. All the signaling pathways on the mechanisms of action involved in the vascular tone regulation have been well described in previous review articles. However, the most appropriate antagonists that should be utilized have never been suggested and elaborated before, hence the reason for this review.
\end{abstract}

Keywords: vasodilators; antagonists; signaling pathway; blood vessel; vascular tone

\section{Introduction}

Cardiovascular diseases are known to be the number one killer in the world, compared to other diseases such as disorders of the blood vessels and the heart. Hypertension is one of the main causes of cardiovascular diseases, and appropriately named as the silent killer due to it being an asymptomatic disease. In addition, it leads to a variety concomitant diseases, including stroke, heart diseases, kidney failure, cerebrovascular diseases, and more [1].Typically, hypertension has been categorized into four classes by the seventh report of Joint National Committee, which includes the normal and pre-hypertension stages, hypertension stage 1 and hypertension stage 2 [2]. Although there are many kinds of anti-hypertensive drugs present in the market nowadays, most have low effectiveness and undesired chronic side effects. Therefore, finding novel anti-hypertensive drugs is still a topic of huge interest to current researchers.

Hypertension is defined as having persistently high pressure exerted throughout the wall of blood vessels [3]. Blood vessels isolated from living organisms are commonly used for the in vitro studies on anti-hypertensive drugs researches [4]. Blood pressure has always been regulated in a narrow range to convey sufficient perfusion for tissues without causing any harm on the vascular system, especially the endothelium and vascular smooth muscle cells. Therefore, it is necessary to 
focus on understanding the signaling mechanism pathways involved in vascular tone regulation, including its way of signaling amplification by producing second messengers and the interaction between enzyme-linked, channel-linked, and G-protein coupled receptors. Plenty of reviews and research articles have discussed the probable signaling mechanism pathways involved in vascular tone regulation, providing great references for researchers, yet none of those discussed which of the signaling mechanisms pathway are significant, or suggest the most appropriate antagonists that should be utilized in respect to their corresponding receptors during studies of mechanistic pathways employed by the test compounds claimed to be exerting vasodilative effects. Therefore, the aim of this review is to provide a general view on the types of mechanistic pathways commonly employed by those researches that are related to this topic and the type of antagonists used. In addition, we aim to provide ideas on which antagonist is the most appropriate to use based on its specificity, selectivity, solubility, reversibility, and affinity to the receptors or enzymes. Finally, we aim to suggest the significance of signaling mechanism pathways to be employed.

This literature review focuses on the articles published during the latest five years (2010 to 2015) and abstracted in PubMed, strictly focusing on studies which meet at least two criteria: (a) the research must involve the use of blood vessels and (b) they must be studies of signaling pathway mechanism of action. Referring to these criteria, 257 articles were selected and reviewed in a comprehensive manner in order to meetthe aims of this review. We did not include in this review papers on reactive oxygen species and unrelated types of mechanistic studies.

\section{Types of Blood Vessels}

All studies involved a classical pharmacological approach using in vitro screening on isolated blood vessels, as shown in the Figure 1. A majority of the studies (67\%) preferred the use of aorta rings for their in vitro studies on vasodilation, followed by mesenteric artery, coronary artery, pulmonary artery, renal artery, carotid artery, basilar artery, femoral artery, retinal arterioles, cerebral artery, and tail artery. Less than 1\% of the studies were performed using saphenous vein, branchial artery, gonadal artery, internal mammary artery, caudal artery, prostatic small artery, afferent arterioles, gallbladder strips, ophthalmic artery, omental artery, bone resistance artery, splenic artery, iliac artery, umbilical artery, and gracilis arterioles.

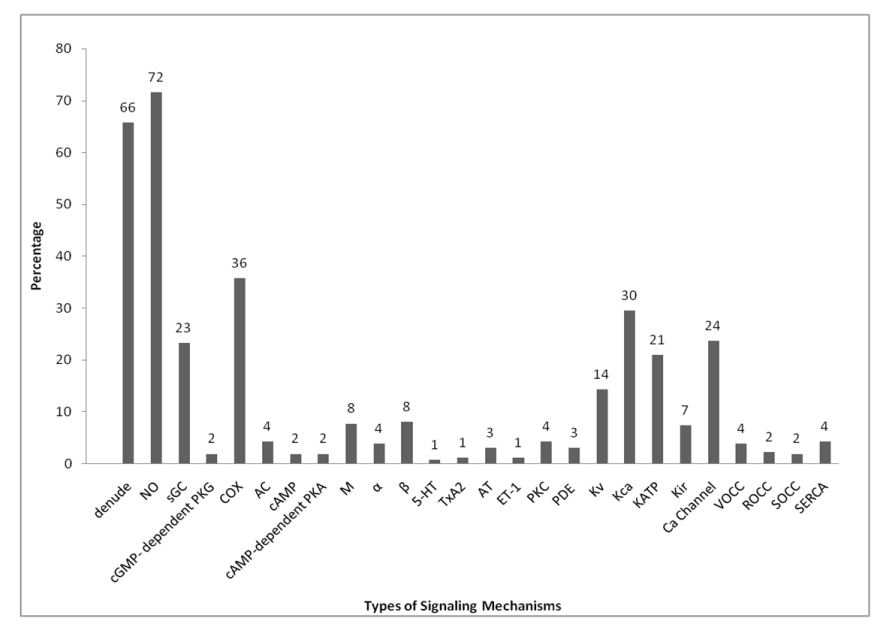

Figure 1. Percentage summary of signaling mechanism pathway studies conducted in research on blood vessel vasodilation published in PubMed from the year 2010 to 2015, as shown in Table 1. There were a total of 257 published research articles that performed research related to the vasodilation of aorta with studies on mechanisms of action within the specified period.

The rat aorta modeling design is the most commonly utilized method for studies on vascular function as well as studies on cell signaling. Using this method, the orientation variation of the smooth muscle cells can be reduced and the damage to the intima surface of the vessel can be minimized during isolation and hanging of the aorta inside the organ bath. In addition, the rat aorta model is a cost-effective, fast, and simple way for in vitro and in vivo vasodilation studies. Hence, it is known to be the "golden tool" in pharmacological researches [5]. 
Table 1. Data tabulation of the signaling mechanism pathways of vasodilation conducted in researches that were published in PubMed from the year 2010-2015.

\begin{tabular}{|c|c|c|c|c|c|c|c|c|c|c|c|c|c|c|c|c|c|c|c|c|c|c|c|c|c|c|}
\hline TOV & D & NO & GC & PKG & $\operatorname{cox}$ & AC & cAMP PKA & $\mathbf{M}$ & $\alpha$ & $\beta$ & $\mathrm{Sr}$ & $\mathrm{T}$ & AT & ET & PKC & PDE & $\mathrm{Kv}$ & Kca & КАТP & Kir & $\mathrm{Ca}$ & $\mathrm{V}$ & $\mathbf{R}$ & $\mathrm{S}$ & SE & Ref. \\
\hline $\mathrm{A}$ & + & + & + & - & + & - & - & + & + & + & - & - & - & - & - & - & - & - & + & - & + & - & - & - & - & {$[6]$} \\
\hline MA & + & + & + & - & + & + & - & - & - & - & - & - & - & - & - & - & + & + & + & + & + & - & - & - & - & [7] \\
\hline A & + & + & + & - & - & - & - & - & + & - & - & - & - & - & - & - & - & + & - & - & + & - & - & - & - & [8] \\
\hline A \& SA & + & + & - & - & + & - & - & - & - & - & - & - & - & - & - & - & - & - & - & - & - & - & - & - & - & [9] \\
\hline $\mathrm{A}$ & - & + & - & - & + & - & - & - & - & - & - & - & - & - & - & - & - & + & - & - & - & - & - & - & - & [10] \\
\hline A & + & + & + & - & + & - & - & + & - & + & + & - & - & - & + & - & + & + & + & + & + & - & - & - & - & [11] \\
\hline A & + & + & - & - & + & - & - & - & - & - & - & - & - & - & - & - & - & - & - & - & - & - & - & - & - & [12] \\
\hline A & - & $\begin{array}{l}+ \\
+\end{array}$ & - & - & - & - & - & - & - & 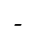 & - & - & - & - & - & 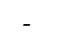 & - & - & - & - & - & - & - & - & - & [13] \\
\hline A & + & + & - & - & + & - & - & - & - & - & - & - & - & - & - & 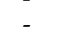 & - & - & - & - & - & - & - & - & + & [14] \\
\hline A & + & + & - & - & - & - & - & - & - & - & - & - & - & - & - & - & - & - & - & - & - & - & - & - & - & [15] \\
\hline A & + & - & - & - & - & - & - & - & - & - & - & - & - & - & - & - & + & + & + & + & + & - & - & - & - & [16] \\
\hline A & + & + & - & - & - & - & - & + & - & - & - & - & - & - & - & - & - & - & - & - & + & - & - & - & - & [17] \\
\hline MA & + & + & + & - & + & + & + & - & - & - & - & - & - & - & - & - & - & - & - & - & - & - & - & - & - & [18] \\
\hline A & + & + & + & - & - & - & - & - & - & - & - & - & - & - & - & - & - & - & - & & + & & - & - & - & [19] \\
\hline A & - & - & - & - & - & - & - & - & - & - & - & - & - & - & - & - & - & - & - & - & - & - & - & - & - & [20] \\
\hline A \& MA & + & + & - & - & - & - & - & - & - & - & - & - & - & - & - & - & - & - & - & - & - & - & - & - & - & [21] \\
\hline A & + & + & + & - & - & - & - & - & - & - & - & - & - & - & - & - & - & + & - & - & + & - & - & - & - & [22] \\
\hline $\mathrm{A}$ & + & + & - & - & + & - & - & - & - & - & - & - & - & - & - & - & - & + & + & - & - & - & - & - & - & [23] \\
\hline RAS & - & + & - & - & + & - & - & - & - & - & - & - & - & - & - & - & - & $\begin{array}{l}+ \\
+\end{array}$ & + & - & - & - & - & - & - & [24] \\
\hline A & + & - & - & - & - & - & - & 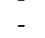 & - & + & - & 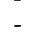 & - & - & - & 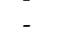 & - & - & - & 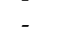 & - & - & - & - & 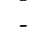 & {$[25]$} \\
\hline $\mathrm{A}$ & + & + & - & - & + & - & 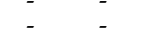 & 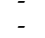 & - & 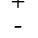 & - & - & - & 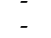 & 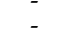 & 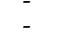 & 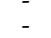 & 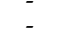 & - & - & - & - & - & - & 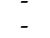 & {$[26]$} \\
\hline $\mathrm{A}$ & + & + & + & + & - & - & - & - & - & - & - & - & - & - & - & + & - & - & - & - & - & - & - & - & - & [27] \\
\hline RAS & - & + & - & - & + & - & - & - & - & - & - & - & - & + & - & - & - & - & - & - & - & - & - & - & - & [28] \\
\hline A & 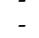 & + & - & 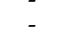 & + & - & - & - & - & 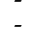 & - & 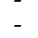 & - & - & - & 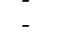 & + & + & + & 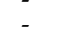 & + & 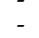 & - & - & 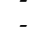 & [29] \\
\hline A & + & + & - & - & - & - & - & - & - & - & - & - & - & - & - & - & + & + & + & + & - & - & - & - & - & [30] \\
\hline A & + & + & - & - & + & - & - & - & - & - & - & - & - & - & - & - & - & - & - & - & + & - & - & - & - & [31] \\
\hline A & + & + & - & - & + & - & - & - & - & - & - & - & - & - & - & - & + & + & + & + & - & - & - & - & - & [32] \\
\hline A & + & + & + & - & + & - & - & + & - & + & - & - & - & - & - & - & - & + & + & - & + & - & - & + & + & [33] \\
\hline $\mathrm{A}$ & + & + & - & - & + & - & - & + & - & - & - & - & - & - & - & - & - & + & + & + & + & - & - & - & - & [34] \\
\hline CA & + & - & + & - & - & + & - & - & - & - & - & - & - & - & - & - & + & + & + & + & + & - & - & - & - & [35] \\
\hline A & + & + & + & - & + & - & + & - & - & - & - & - & - & - & - & - & - & - & - & - & + & - & - & - & - & [36] \\
\hline A & + & + & + & - & - & - & - & - & - & - & - & - & - & - & - & - & - & - & - & - & + & - & - & - & - & [37] \\
\hline GA, BLA \& A & + & + & + & - & + & - & - & - & - & - & - & - & - & - & - & - & - & - & - & - & - & - & - & - & - & [38] \\
\hline A & + & + & - & - & - & - & - & - & - & - & - & - & - & - & - & - & - & - & - & - & + & - & - & - & - & [39] \\
\hline CA & - & $\begin{array}{l}+ \\
+\end{array}$ & + & - & - & - & - & - & - & - & - & - & - & - & 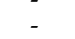 & - & - & - & - & - & - & - & - & - & 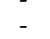 & [40] \\
\hline A & + & $\begin{array}{l}+ \\
+\end{array}$ & $\stackrel{+}{-}$ & - & - & - & - & - & - & - & - & - & - & - & + & - & - & - & - & - & - & + & - & - & - & {$[41]$} \\
\hline $\mathrm{A}$ & + & + & - & - & - & - & - & - & - & - & - & - & + & - & - & - & - & - & - & - & - & - & - & - & - & [42] \\
\hline MA & + & - & + & 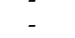 & - & - & - & - & - & - & - & 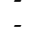 & - & - & - & 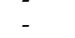 & + & + & + & - & - & - & - & - & - & [43] \\
\hline A & + & + & $\stackrel{+}{-}$ & - & + & - & - & - & - & - & - & - & - & - & - & - & 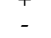 & $\stackrel{+}{-}$ & 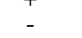 & - & - & - & - & - & - & {$[44]$} \\
\hline A & - & 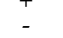 & + & - & 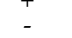 & - & 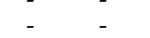 & - & - & $=$ & - & - & - & 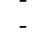 & - & + & - & + & - & - & - & - & - & - & + & {$[45]$} \\
\hline A & - & + & - & - & + & - & - & + & - & - & - & - & - & - & - & - & + & + & + & - & - & - & - & - & - & [46] \\
\hline $\mathrm{A}$ & + & + & + & - & - & - & - & - & - & - & - & - & - & - & - & 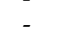 & + & - & - & - & - & - & - & - & - & {$[47]$} \\
\hline $\mathrm{A}$ & - & + & - & - & - & - & - & - & - & - & - & - & - & - & - & - & - & - & - & - & + & - & - & - & - & {$[48]$} \\
\hline A & + & + & - & - & - & - & - & - & - & - & - & - & - & - & - & - & - & - & + & - & - & - & - & - & - & [49] \\
\hline MA & - & + & - & - & + & - & - & - & - & - & - & - & - & - & - & - & - & - & - & - & - & - & - & - & - & [50] \\
\hline A & + & + & - & - & - & - & - & + & - & - & - & - & - & - & - & - & - & - & - & - & - & - & - & - & - & [51] \\
\hline A & - & + & - & - & + & - & - & - & - & - & - & - & - & - & - & - & - & - & - & - & - & - & - & - & - & [52] \\
\hline $\mathrm{A}$ & + & - & - & - & - & - & - & - & + & - & - & - & + & - & - & - & - & - & - & - & - & - & - & - & - & [53] \\
\hline IMA & - & + & + & - & + & - & - & + & - & - & - & - & 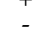 & + & - & 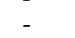 & + & + & + & + & - & - & - & - & - & [54] \\
\hline A & + & + & - & - & - & - & - & - & + & + & - & - & - & + & - & - & - & - & - & - & - & - & - & - & - & [55] \\
\hline $\mathrm{A}$ & + & + & - & - & - & - & - & - & $\stackrel{+}{-}$ & 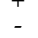 & - & - & - & $\begin{array}{l}+ \\
-\end{array}$ & + & 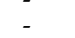 & - & - & - & 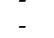 & - & - & - & 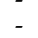 & - & {$[56]$} \\
\hline
\end{tabular}


Table 1. Cont

\begin{tabular}{|c|c|c|c|c|c|c|c|c|c|c|c|c|c|c|c|c|c|c|c|c|c|c|c|c|c|c|}
\hline TOV & D & NO & GC & PKG & $\operatorname{cox}$ & AC & cAMP PKA & M & $\alpha$ & $\beta$ & $\mathrm{Sr}$ & $\mathrm{T}$ & AT & ET & PKC & PDE & Kv & Kca & KATP & Kir & $\mathrm{Ca}$ & $\mathrm{v}$ & $\mathbf{R}$ & $\mathrm{s}$ & SE & Ref. \\
\hline IMA & + & - & - & - & - & - & - & - & - & - & - & - & - & - & - & - & + & + & + & - & + & - & - & - & + & [57] \\
\hline A & + & + & - & - & + & - & - & - & - & - & - & - & - & - & + & - & - & - & - & + & + & - & - & - & - & [58] \\
\hline A & + & + & - & - & - & - & - & - & - & - & - & - & - & - & - & - & - & - & - & - & - & - & - & - & - & [59] \\
\hline $\mathrm{A}$ & + & + & - & - & - & - & - & - & - & - & - & - & - & - & - & - & - & + & - & - & - & - & - & - & - & {$[60]$} \\
\hline A & + & + & + & - & + & - & - & + & - & - & - & - & - & - & - & - & - & - & + & - & - & - & - & - & - & [61] \\
\hline CBA & - & - & - & - & - & - & - & - & - & - & - & - & - & - & - & - & - & - & - & - & + & - & - & - & - & [62] \\
\hline A & + & + & + & - & + & - & - & - & - & + & - & - & - & - & - & - & - & - & - & - & - & - & - & - & - & [63] \\
\hline A & - & + & - & - & + & - & - & - & - & - & - & - & - & - & - & - & - & - & - & - & - & - & - & - & - & [64] \\
\hline A & + & + & - & - & - & - & - & - & - & + & - & - & - & - & - & - & - & + & + & - & - & - & - & - & - & [65] \\
\hline A & + & + & - & - & + & - & - & - & - & - & - & - & - & - & - & - & - & - & - & - & - & - & - & - & - & {$[66]$} \\
\hline MA & + & + & - & - & - & - & - & - & - & - & - & - & - & - & + & - & - & - & - & - & - & - & - & - & - & [6] \\
\hline A & + & + & + & - & + & - & - & - & - & - & - & - & - & - & - & - & + & + & + & + & + & - & - & - & - & {$[68]$} \\
\hline A & + & + & + & - & + & - & - & - & - & + & - & - & - & - & - & - & - & + & + & + & + & - & - & - & - & {$[69]$} \\
\hline $\mathrm{A}$ & + & + & - & - & - & - & - & - & - & - & - & - & + & - & - & - & - & - & - & - & - & - & - & - & - & {$[70]$} \\
\hline CA & - & + & + & + & - & + & - & - & - & - & - & - & - & - & - & - & - & - & - & - & - & - & - & - & - & [71] \\
\hline A & - & + & - & - & - & - & - & - & - & - & - & - & - & - & - & - & - & - & - & - & - & - & - & - & - & [72] \\
\hline A & + & + & - & - & + & - & - & + & - & + & - & - & - & - & - & - & - & + & + & - & - & - & - & - & - & [73] \\
\hline A & + & - & - & - & - & - & - & - & - & - & - & - & - & - & - & - & - & - & - & - & - & - & - & - & - & {$[74]$} \\
\hline A & + & + & - & - & - & - & - & - & - & + & - & - & - & - & - & - & - & - & - & - & - & - & - & - & - & [75] \\
\hline A & + & + & - & - & - & - & - & - & - & - & - & - & - & - & - & - & - & - & - & - & - & - & - & - & - & [76] \\
\hline RA & - & + & - & - & - & - & - & - & - & - & - & - & - & - & - & - & - & + & + & + & - & - & - & - & - & [77] \\
\hline A & + & + & - & - & - & - & - & - & - & - & - & - & - & - & - & - & - & - & - & - & - & - & - & - & - & [78] \\
\hline A & + & + & - & - & + & - & - & - & - & - & - & + & - & - & - & - & - & - & - & - & - & - & - & - & - & [79] \\
\hline A & - & + & - & - & - & - & - & - & - & - & - & - & - & - & - & - & - & - & - & - & - & - & - & - & - & {$[80]$} \\
\hline A & - & + & - & - & - & - & - & - & + & + & - & - & - & - & - & - & - & - & - & - & - & - & - & - & - & [81] \\
\hline A & + & + & + & - & + & - & - & + & - & + & - & - & - & - & - & - & - & + & + & - & - & - & - & - & - & {$[82]$} \\
\hline MA & - & + & - & - & - & - & - & - & - & - & - & - & - & - & - & - & - & + & + & + & - & - & - & - & - & {$[83]$} \\
\hline A & + & + & - & - & + & - & - & - & - & - & - & + & + & - & - & - & - & - & - & - & - & - & - & - & - & {$[84]$} \\
\hline $\mathrm{A}$ & - & + & + & 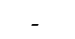 & - & 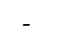 & 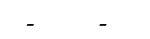 & 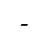 & - & 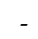 & 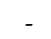 & - & - & 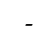 & 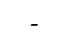 & 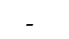 & 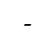 & + & + & + & + & 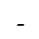 & 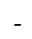 & - & 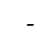 & {$[85]$} \\
\hline A & + & - & - & - & + & - & - & - & - & - & - & + & - & - & - & - & - & - & - & - & - & - & - & - & - & {$[86]$} \\
\hline A & + & + & + & - & - & - & - & - & - & - & - & - & - & - & - & - & - & - & - & - & - & - & - & - & - & {$[87]$} \\
\hline A & - & + & - & - & - & - & - & - & - & - & - & - & - & - & - & - & - & - & - & - & - & - & - & - & - & {$[88]$} \\
\hline A & + & + & + & - & + & - & - & - & - & - & - & - & - & - & - & - & + & + & + & - & - & - & - & - & - & {$[89]$} \\
\hline A & - & + & - & - & + & - & - & - & - & - & - & - & - & - & - & - & + & + & + & - & - & - & - & - & - & {$[90]$} \\
\hline A & + & + & + & - & + & - & - & + & - & - & - & - & - & - & - & - & - & - & - & - & - & - & - & - & - & [91] \\
\hline A & + & + & + & - & + & - & - & - & - & - & - & - & - & - & - & - & - & - & - & - & - & - & - & - & - & [92] \\
\hline A & - & + & - & - & + & - & - & - & - & - & - & - & - & - & - & - & - & - & - & - & - & - & - & - & - & [93] \\
\hline A & + & + & + & - & + & - & - & + & - & + & - & - & - & - & - & - & - & + & + & - & + & - & - & + & + & [94] \\
\hline A & + & + & + & - & + & - & - & + & - & + & - & - & - & - & - & - & - & + & + & - & + & - & - & + & + & [95] \\
\hline CRA & + & + & + & - & + & - & - & - & - & - & - & - & - & - & - & - & + & + & + & - & + & - & - & + & + & {$[96]$} \\
\hline A & + & + & + & - & + & - & - & - & - & - & - & - & - & - & - & - & - & - & - & - & - & - & - & - & - & [97] \\
\hline A & + & - & + & - & - & + & - & - & - & - & - & - & - & - & - & - & + & + & + & - & - & - & - & - & + & [98] \\
\hline A & + & - & - & - & - & - & - & - & - & - & - & - & - & - & - & - & + & + & + & - & + & - & - & - & - & [99] \\
\hline A & + & - & - & - & - & - & - & - & - & - & - & - & - & - & - & - & - & - & - & - & + & - & - & - & - & {$[100]$} \\
\hline A & - & + & - & - & - & - & + & - & - & - & - & - & - & - & - & - & - & - & - & - & - & - & - & - & - & [101] \\
\hline BA & + & - & - & - & - & - & - & - & - & - & - & - & - & - & - & - & + & + & + & + & + & - & - & - & - & {$[102]$} \\
\hline A & + & + & + & - & + & - & - & + & - & + & - & - & - & - & - & - & + & + & + & - & + & + & + & - & - & {$[103]$} \\
\hline A & + & - & - & - & - & - & - & - & - & - & - & - & - & - & - & - & - & - & - & - & + & - & - & - & - & {$[104]$} \\
\hline A & + & + & - & - & - & - & - & - & - & - & - & - & - & - & - & - & - & - & - & - & - & - & - & - & - & {$[105]$} \\
\hline A & - & - & - & - & - & - & - & - & - & - & - & - & + & - & - & - & - & - & - & - & - & - & - & - & - & {$[106]$} \\
\hline A & + & + & + & - & + & - & - & - & - & + & - & - & - & - & + & - & + & + & + & - & + & - & - & - & - & [107] \\
\hline A & + & - & - & - & - & - & - & - & - & - & - & - & - & - & - & - & + & + & + & - & + & + & + & - & + & [108] \\
\hline A & + & + & + & + & + & - & - & + & - & - & - & - & - & - & - & - & - & + & - & - & - & - & - & - & - & [109] \\
\hline A & + & + & - & - & + & - & - & - & - & - & - & - & - & - & - & - & - & + & - & - & + & - & - & - & - & [110] \\
\hline A & + & + & - & - & - & - & - & - & - & - & - & - & - & - & - & - & - & - & - & - & - & - & - & - & - & [111] \\
\hline A & + & + & - & - & - & - & - & - & - & - & - & - & - & - & - & - & - & - & - & - & + & - & - & - & - & [112] \\
\hline $\mathrm{A}$ & + & + & - & - & + & - & - & - & - & - & - & - & - & - & - & - & - & - & - & - & - & - & - & - & - & {$[113]$} \\
\hline
\end{tabular}


Table 1. Cont.

\begin{tabular}{|c|c|c|c|c|c|c|c|c|c|c|c|c|c|c|c|c|c|c|c|c|c|c|c|c|c|c|}
\hline TOV & D & NO & GC & PKG & COX & AC & cAMP PKA & M & $\alpha$ & $\beta$ & $\mathrm{Sr}$ & $\mathrm{T}$ & AT & ET & PKC & PDE & Kv & Kса & KATP & Kir & $\mathrm{Ca}$ & v & $\mathbf{R}$ & $\mathrm{S}$ & SE & Ref. \\
\hline CA & + & + & + & - & + & - & - & - & - & - & - & - & - & - & - & - & - & + & - & - & - & - & - & - & - & [114] \\
\hline A & + & - & - & - & - & - & - & - & - & - & - & - & - & - & - & - & - & - & - & - & - & - & - & - & - & [115] \\
\hline$\underset{A}{R A} \& A$ & $\begin{array}{c}- \\
+\end{array}$ & $\begin{array}{l}+ \\
+\end{array}$ & - & - & $\begin{array}{lll}- \\
+\end{array}$ & - & - & - & - & - & - & - & - & - & - & - & - & - & - & - & $\bar{y}^{-}$ & - & - & & - & [116] \\
\hline $\begin{array}{c}\text { A } \\
\text { RAS }\end{array}$ & $\begin{array}{lll}+ \\
+\end{array}$ & $\begin{array}{l}+ \\
-\end{array}$ & - & - & $\begin{array}{l}+ \\
-\end{array}$ & - & - & - & - & - & - & 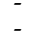 & - & - & + & - & - & - & - & - & $\begin{array}{lll}+ \\
+\end{array}$ & $\bar{z}^{-}$ & - & - & - & {$[117]$} \\
\hline A & + & + & - & 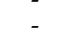 & + & - & - & + & - & - & + & - & - & - & - & - & - & 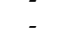 & - & 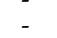 & $\begin{array}{l}+ \\
-\end{array}$ & $\begin{array}{l}+ \\
-\end{array}$ & - & - & - & {$[118]$} \\
\hline A & + & + & - & - & - & - & - & - & - & - & - & - & - & - & - & - & - & - & - & - & - & - & - & - & - & [120] \\
\hline A & + & - & - & - & - & - & - & - & - & - & - & - & - & - & - & - & - & - & - & - & - & - & - & - & - & [121] \\
\hline A \& TA & + & + & - & - & - & - & - & - & - & - & - & - & - & - & - & - & - & - & - & - & - & - & - & - & - & [122] \\
\hline PA & - & - & - & - & - & - & - & - & - & - & - & - & - & - & - & - & - & - & - & - & + & - & - & - & - & [123] \\
\hline $\mathrm{A}$ & + & + & - & - & - & - & - & - & - & - & - & - & - & - & - & - & - & - & + & - & - & - & - & - & - & [124] \\
\hline $\mathrm{A}$ & - & + & - & - & - & - & - & - & - & - & - & - & - & - & - & - & - & - & - & - & - & - & - & - & - & [125] \\
\hline FA & + & + & - & - & - & - & - & - & - & - & - & - & - & - & - & - & - & - & - & - & - & - & - & - & - & [126] \\
\hline MA \& A & + & + & + & - & - & - & - & - & - & - & - & - & - & - & - & - & + & + & + & - & - & - & - & - & - & [127] \\
\hline CA & + & + & - & - & - & - & - & - & - & - & - & - & + & - & - & - & - & - & - & - & - & - & - & - & - & [128] \\
\hline CA \& SPA & + & + & - & - & - & - & - & - & - & - & - & - & - & - & - & + & - & + & - & - & + & - & - & - & - & [129] \\
\hline CRA & + & + & - & - & + & - & - & - & - & - & - & - & - & - & - & - & + & + & + & - & - & - & - & - & - & [130] \\
\hline A & + & - & - & - & - & - & - & - & - & - & - & - & - & - & - & - & - & - & - & - & - & - & - & - & - & [131] \\
\hline MA & - & + & - & - & + & - & - & - & - & - & - & - & - & - & - & - & - & - & - & - & - & - & - & - & - & [132] \\
\hline A & - & - & - & - & - & - & - & - & + & - & - & - & - & - & - & - & - & - & - & - & - & - & - & - & - & [133] \\
\hline $\mathrm{A}$ & + & + & + & - & + & - & - & + & - & + & - & - & - & - & - & - & - & + & + & - & + & - & - & + & + & [134] \\
\hline A & - & + & - & - & - & - & - & - & - & - & - & - & - & - & - & - & - & - & - & - & - & - & - & - & - & [135] \\
\hline A & + & - & - & - & - & - & - & - & - & - & - & - & - & - & - & - & + & + & + & - & - & - & - & - & - & {$[136]$} \\
\hline PA & + & + & + & - & + & - & - & - & - & - & - & - & - & - & - & - & - & + & - & - & - & - & - & - & - & [137] \\
\hline PA & + & - & - & - & - & - & - & - & - & - & - & - & - & - & - & - & - & + & - & - & - & - & - & - & - & [138] \\
\hline $\mathrm{BA}$ & - & + & - & - & + & - & - & - & - & + & - & - & - & - & - & - & - & - & - & - & + & - & - & - & - & [139] \\
\hline A & + & - & - & - & - & - & - & - & - & - & - & - & - & - & - & - & - & - & - & - & - & - & - & - & - & [140] \\
\hline A & + & - & - & - & & - & - & - & - & - & - & - & - & - & - & - & - & - & - & - & - & - & - & - & - & [141] \\
\hline A & - & - & - & - & - & - & - & - & - & - & - & - & - & - & - & - & - & - & - & - & - & - & - & - & - & {$[142]$} \\
\hline A & + & - & - & - & - & - & - & - & - & - & - & - & - & - & - & - & - & - & - & - & - & - & - & - & - & {$[143]$} \\
\hline IA & - & - & - & - & + & - & - & - & - & - & - & - & - & - & - & - & - & - & - & - & - & - & - & - & - & [144] \\
\hline A & + & + & - & - & - & - & - & - & - & - & - & - & - & - & - & - & - & - & - & - & - & - & - & - & - & [145] \\
\hline CA & + & - & - & - & - & - & - & - & - & - & - & - & - & - & - & - & - & - & - & - & - & - & - & - & 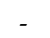 & [146] \\
\hline A & + & - & - & - & + & - & - & - & - & - & - & - & - & - & - & - & - & - & - & - & - & - & - & - & - & [147] \\
\hline A & + & - & - & - & - & - & - & - & - & - & - & - & - & - & - & - & - & - & - & - & - & - & - & - & - & [148] \\
\hline A & + & - & - & - & - & - & - & - & - & - & - & - & - & - & - & - & - & - & - & - & - & - & - & - & - & [149] \\
\hline A & + & - & - & - & - & - & - & - & - & - & - & - & - & - & - & - & - & - & - & - & - & - & - & - & - & {$[150]$} \\
\hline RA & - & + & - & - & - & - & - & - & - & - & - & - & - & - & - & - & - & - & - & - & - & - & - & - & - & [151] \\
\hline $\mathrm{VA}$ & - & + & + & - & - & + & - & - & - & - & - & - & - & - & - & - & - & - & - & - & - & - & - & - & - & [152] \\
\hline A & + & + & - & - & - & - & - & - & - & - & - & - & - & - & - & - & + & + & - & - & - & - & - & - & - & [153] \\
\hline A & + & + & - & - & - & - & - & - & - & - & - & - & - & - & - & - & + & + & - & - & - & - & - & - & - & [154] \\
\hline A & + & - & - & - & - & + & - & - & - & - & - & - & - & - & - & + & - & - & - & - & - & - & - & - & - & [155] \\
\hline GCA & - & + & - & - & - & - & - & - & - & - & - & - & - & - & - & - & - & - & - & - & - & - & - & - & - & {$[156]$} \\
\hline PA & + & - & - & - & - & - & - & - & - & - & - & - & - & - & - & - & - & + & - & - & - & - & - & - & - & [157] \\
\hline A & - & + & - & - & - & - & - & - & - & - & - & - & - & - & - & - & - & - & - & - & - & - & - & - & - & [158] \\
\hline A & + & + & + & - & + & + & - & - & - & - & - & - & - & - & + & - & - & + & + & - & + & - & - & - & - & [159] \\
\hline A & + & + & - & - & - & - & - & - & - & - & - & - & - & - & - & - & + & + & - & + & - & - & - & - & - & {$[160]$} \\
\hline A & - & + & - & - & - & - & - & - & - & - & - & - & - & - & - & - & - & - & - & - & - & - & - & - & - & [161] \\
\hline A & - & + & - & - & - & - & - & - & - & - & - & - & - & - & - & - & - & - & - & - & - & - & - & - & - & [162] \\
\hline A & + & + & - & - & + & - & - & - & - & - & - & - & - & - & - & - & - & - & - & - & - & - & - & - & - & [163] \\
\hline MA & - & + & - & - & + & + & + & - & - & + & - & - & - & - & - & - & - & + & + & - & - & - & - & - & - & [164] \\
\hline CA & - & + & - & - & - & - & - & - & - & - & - & - & - & - & - & - & - & - & - & - & - & - & - & - & - & [165] \\
\hline $\mathrm{A}$ & + & + & + & - & + & - & - & - & - & - & - & - & - & - & - & - & - & - & - & - & - & - & - & - & - & [166] \\
\hline
\end{tabular}


Table 1. Cont

\begin{tabular}{|c|c|c|c|c|c|c|c|c|c|c|c|c|c|c|c|c|c|c|c|c|c|c|c|c|c|c|}
\hline TOV & D & NO & GC & PKG & $\operatorname{cox}$ & AC & cAMP PKA & M & $\alpha$ & $\beta$ & $\mathrm{Sr}$ & $\mathrm{T}$ & AT & ET & PKC & PDE & $\mathrm{Kv}$ & Kca & KATP & Kir & $\mathrm{Ca}$ & $\mathrm{V}$ & $\mathbf{R}$ & $\mathrm{s}$ & SE & Ref. \\
\hline A & + & + & - & - & - & - & - & - & - & - & - & - & - & - & - & - & - & - & - & - & - & - & - & - & - & [167] \\
\hline GCA & - & + & - & - & - & - & - & - & - & - & - & - & - & - & - & - & - & - & - & - & - & - & - & - & - & {$[168]$} \\
\hline A & + & + & - & - & - & - & - & - & - & - & - & - & + & - & - & - & - & - & - & - & - & - & - & - & - & {$[169]$} \\
\hline A & - & - & - & - & - & - & - & - & - & - & - & - & - & - & - & - & - & - & - & - & - & - & - & - & - & {$[170]$} \\
\hline $\mathrm{PA}$ & - & - & - & - & - & - & - & - & - & - & - & - & - & - & - & - & - & - & - & - & - & - & - & - & - & [171] \\
\hline A & - & - & - & - & - & - & - & - & - & - & - & - & - & - & - & - & - & - & - & - & - & - & - & - & - & {$[172]$} \\
\hline CA & - & - & - & - & - & - & - & - & + & - & - & - & - & - & - & - & - & - & - & - & + & - & - & - & - & {$[173]$} \\
\hline MA & + & + & - & - & - & - & - & - & - & - & - & - & - & - & - & - & - & - & - & - & - & - & - & - & - & [174 \\
\hline A & - & + & - & - & + & - & - & - & - & - & - & - & - & - & - & - & - & - & - & - & - & - & - & - & - & {$[175]$} \\
\hline A & + & + & + & - & + & - & - & - & - & - & - & - & - & - & - & - & - & - & - & - & + & - & - & - & - & [176] \\
\hline CA & - & - & - & - & - & - & - & - & - & - & - & - & - & - & - & - & - & - & - & - & + & - & - & - & - & [177] \\
\hline A & + & - & + & - & + & - & - & - & - & - & - & - & - & - & - & - & - & - & - & - & - & - & - & - & - & {$[178]$} \\
\hline A & + & + & - & - & - & - & - & - & - & - & - & - & - & - & - & - & - & + & - & - & + & + & + & - & - & {$[179]$} \\
\hline A & + & + & - & - & - & - & - & - & - & - & - & - & - & - & - & - & - & + & - & - & + & + & + & - & - & {$[180]$} \\
\hline A & - & + & - & - & + & - & - & - & - & - & - & - & - & - & - & - & - & - & - & - & - & - & - & - & - & [181] \\
\hline FA & + & + & - & - & + & - & - & - & - & - & - & - & + & - & - & - & - & - & - & - & - & - & - & - & - & {$[182]$} \\
\hline A & + & + & - & - & - & - & - & - & - & - & - & - & - & - & - & - & - & - & + & - & - & - & - & - & - & {$[183]$} \\
\hline CA & + & + & - & - & + & - & - & - & - & - & - & - & - & - & - & - & - & + & - & - & + & - & - & - & - & {$[184]$} \\
\hline $\mathrm{A}$ & - & - & + & - & - & - & - & - & - & - & - & - & - & - & - & - & - & - & - & - & - & - & - & - & - & {$[185]$} \\
\hline A & - & + & - & - & + & - & - & - & - & - & - & - & - & - & - & - & - & - & - & - & - & - & - & - & - & {$[186]$} \\
\hline A & + & - & + & - & - & - & - & - & - & - & - & - & - & - & - & + & - & - & - & - & - & - & - & - & - & [187] \\
\hline PA & - & + & - & - & - & - & - & - & - & - & - & - & - & - & - & - & - & - & - & - & - & - & - & - & - & [188] \\
\hline A & + & - & - & - & - & - & - & - & + & - & - & - & - & - & - & - & - & - & - & - & - & - & - & - & - & [189] \\
\hline MA & + & + & + & - & + & - & - & + & - & - & - & - & - & - & - & - & - & + & - & - & + & - & - & - & - & {$[190]$} \\
\hline A & + & + & - & - & - & - & - & - & - & - & - & - & - & - & - & - & - & - & - & - & - & - & - & - & - & [191] \\
\hline A & - & - & - & - & - & - & - & - & + & - & - & - & - & - & - & - & - & - & - & - & - & - & - & - & - & {$[192]$} \\
\hline PA & + & + & - & - & + & - & - & - & - & - & - & - & - & - & - & - & + & + & + & + & + & - & - & - & - & [193] \\
\hline A & + & + & - & - & - & - & - & - & - & - & - & - & - & - & - & - & - & - & - & - & - & - & - & - & - & {$[194]$} \\
\hline A & - & + & - & - & - & - & - & - & - & - & - & - & - & - & - & - & - & - & - & - & - & - & - & - & - & [195] \\
\hline A & + & + & - & - & + & - & - & - & - & - & - & - & - & - & - & - & - & - & - & - & - & - & - & - & - & {$[196]$} \\
\hline PA & - & + & - & - & + & - & - & - & - & - & - & - & - & - & - & - & - & - & - & - & - & - & - & - & - & [197] \\
\hline BA & + & - & - & - & - & - & - & - & - & - & - & - & - & - & - & - & - & + & - & - & - & - & - & - & - & {$[198]$} \\
\hline PA & + & + & - & - & - & - & - & - & - & - & - & - & - & - & - & - & - & - & - & - & + & - & - & - & - & [199] \\
\hline BA & - & + & - & - & + & - & - & - & - & - & - & - & - & - & - & - & - & + & - & + & - & - & - & - & - & {$[200]$} \\
\hline PSA & + & + & + & - & + & - & - & - & - & - & - & - & - & - & - & - & + & + & + & - & + & - & - & - & - & [201] \\
\hline A & + & + & + & - & + & - & - & - & - & - & - & - & - & - & - & - & + & + & + & - & - & - & - & - & - & [202] \\
\hline MA & + & - & + & - & - & - & - & - & - & - & - & - & - & - & - & - & + & + & + & - & - & - & - & - & - & [203] \\
\hline$C A \& F A$ & + & - & - & - & - & - & - & - & - & - & - & - & - & - & - & - & - & - & - & - & - & - & - & - & - & [204] \\
\hline A & + & - & - & - & - & - & - & - & - & - & - & - & - & - & - & - & - & + & - & - & + & + & + & - & - & {$[205]$} \\
\hline RA & + & + & - & - & + & - & - & - & - & - & - & - & - & - & - & - & + & + & + & - & - & - & - & - & - & [206] \\
\hline AA & - & + & - & - & - & - & - & - & - & - & - & - & - & - & - & - & - & - & - & - & - & - & - & - & - & [207] \\
\hline A & - & - & - & - & + & - & - & - & - & - & - & - & - & - & - & - & - & - & - & - & - & - & - & - & - & {$[208]$} \\
\hline $\mathrm{A}$ & - & + & - & - & + & - & - & - & - & - & - & - & - & - & - & - & - & - & - & - & - & - & - & - & - & {$[209]$} \\
\hline TA & - & - & - & - & - & - & - & - & - & - & - & - & - & - & - & - & - & - & - & - & - & - & - & - & - & {$[210]$} \\
\hline A & + & - & - & - & - & - & - & - & - & - & - & - & - & - & - & - & - & - & - & - & - & - & - & - & - & [211] \\
\hline A & + & + & - & - & - & - & - & - & - & - & - & - & - & - & + & - & & - & + & - & - & - & - & - & - & {$[212$} \\
\hline A & + & - & - & - & - & - & - & - & - & - & - & - & - & - & - & + & - & - & - & - & + & - & - & - & - & [213] \\
\hline A & + & + & - & - & - & - & - & - & - & - & - & - & - & - & - & - & + & + & - & - & + & + & + & - & - & {$[214]$} \\
\hline PA & - & - & - & - & + & - & - & - & - & - & - & - & - & - & - & + & - & - & - & - & - & - & - & - & - & {$[215]$} \\
\hline RAS & + & + & + & - & + & - & - & - & - & - & - & - & - & - & - & - & + & + & + & - & - & - & - & - & - & [216] \\
\hline MA & - & - & - & - & + & - & - & - & - & + & - & - & - & - & - & - & - & - & - & - & - & - & - & - & - & [217] \\
\hline CA & + & + & - & - & - & - & - & - & - & - & - & - & - & - & - & - & - & - & - & - & - & - & - & - & - & [218] \\
\hline A & - & + & - & - & - & - & - & - & - & - & - & - & - & - & - & - & - & - & - & - & + & - & - & - & + & [219] \\
\hline A & + & - & - & - & - & - & - & - & - & - & - & - & - & - & - & - & - & - & - & - & - & - & - & - & - & {$[220]$} \\
\hline A & - & - & + & - & - & - & - & - & - & - & - & - & - & - & - & - & - & - & - & - & - & - & - & - & - & {$[221]$} \\
\hline A & + & + & - & - & - & - & - & - & - & - & - & - & - & - & - & - & - & - & - & - & - & - & - & - & - & [222] \\
\hline
\end{tabular}


Table 1. Cont

\begin{tabular}{|c|c|c|c|c|c|c|c|c|c|c|c|c|c|c|c|c|c|c|c|c|c|c|c|c|c|c|}
\hline TOV & D & NO & GC & PKG & $\operatorname{cox}$ & AC & cAMP PKA & $\mathbf{M}$ & $\alpha$ & $\beta$ & Sr & $\mathrm{T}$ & AT & ET & PKC & PDE & $\mathrm{Kv}$ & Kca & KATP & Kir & $\mathrm{Ca}$ & $\mathrm{V}$ & $\mathbf{R}$ & $\mathrm{S}$ & SE & Ref. \\
\hline MA & - & + & + & + & + & + & + & - & - & - & - & - & - & - & - & - & - & + & - & - & - & + & - & - & - & [223] \\
\hline CRA & + & + & - & - & + & - & - & - & - & - & - & - & - & - & - & - & - & + & - & - & + & - & - & - & - & [224] \\
\hline A & + & + & - & - & - & - & - & - & - & - & - & - & - & - & - & - & - & - & - & - & - & - & - & - & - & [225] \\
\hline A, CA, MA \& RA & - & + & - & - & - & - & - & - & - & - & - & - & - & - & - & - & - & - & - & - & + & - & - & - & - & [226] \\
\hline A & + & + & - & - & - & - & - & - & - & - & - & - & - & - & - & - & - & + & - & - & - & - & - & - & - & [227] \\
\hline A \& FA & - & - & - & - & - & - & - & - & - & - & - & - & - & - & - & - & - & - & - & - & - & - & - & - & - & [228] \\
\hline A & - & + & - & - & - & - & - & - & - & - & - & - & - & - & - & - & - & - & - & - & - & - & - & - & - & [229] \\
\hline A & - & - & + & - & - & - & - & - & - & - & - & - & - & - & - & - & - & - & - & - & - & - & - & - & - & [230] \\
\hline RA & + & + & - & - & + & - & - & - & - & - & - & - & - & - & - & - & - & + & - & - & + & - & - & - & - & [231] \\
\hline MA & - & + & - & - & + & - & - & - & - & - & - & - & - & - & - & - & - & + & - & - & - & - & - & - & - & [232] \\
\hline A & - & + & - & - & - & - & - & - & - & - & - & - & - & - & - & - & - & - & - & - & - & - & - & - & - & [233] \\
\hline A & - & + & - & - & - & - & - & - & - & - & - & - & - & - & - & - & - & - & - & - & - & - & - & - & - & [234] \\
\hline MA & - & + & - & - & - & - & - & - & - & - & - & - & - & - & - & - & - & - & - & - & - & - & - & - & - & [235] \\
\hline RSA & + & + & - & - & + & - & - & - & - & - & - & - & - & - & - & - & - & - & - & - & + & - & - & - & - & [236] \\
\hline A & + & + & - & - & - & - & - & - & - & - & - & - & - & - & - & - & - & - & - & - & - & - & - & - & - & [237] \\
\hline A & + & - & + & - & - & - & - & - & - & - & - & - & - & - & - & - & - & - & - & - & - & - & - & - & - & [238] \\
\hline A & + & + & - & - & - & - & - & - & - & - & - & - & - & - & - & - & - & - & - & - & - & - & - & - & - & [239] \\
\hline MA & - & + & - & - & + & - & - & - & - & - & - & - & - & - & - & - & - & - & - & - & - & - & - & - & - & [240] \\
\hline GS & 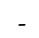 & + & - & 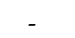 & - & - & + & - & - & - & - & - & - & - & + & - & - & - & 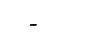 & - & - & - & - & - & - & {$[241]$} \\
\hline OPA & - & + & - & - & - & - & - & - & - & - & - & - & - & - & - & - & - & - & - & - & - & - & - & - & - & [242] \\
\hline A & - & - & - & - & - & - & - & - & - & - & - & - & - & - & - & - & - & - & - & - & - & - & - & - & - & [243] \\
\hline CRA & + & - & - & - & - & - & - & - & - & - & - & - & - & - & - & - & - & - & - & - & - & - & - & - & - & [244] \\
\hline A & + & - & - & - & - & - & - & - & - & - & - & - & - & - & - & - & - & - & - & - & - & - & - & - & - & [245] \\
\hline MA & + & + & - & - & + & - & - & - & - & - & - & - & - & - & - & - & - & - & - & - & - & - & - & - & - & [246] \\
\hline A & - & + & - & - & - & - & - & - & - & - & - & - & - & - & - & - & - & - & - & - & - & - & - & - & - & [247] \\
\hline CA & - & + & - & - & - & - & - & - & - & - & - & - & - & - & + & - & - & - & - & - & - & - & - & - & - & [248] \\
\hline MA & - & + & - & - & - & - & - & - & + & - & - & - & - & - & - & - & - & - & - & - & - & - & - & - & - & [249] \\
\hline CBA, BA \& MA & - & - & - & - & - & - & - & - & - & - & - & - & - & - & - & - & - & - & - & - & + & - & - & - & - & {$[250]$} \\
\hline CA & + & - & - & + & - & - & - & - & - & - & - & - & - & - & - & - & - & - & - & - & - & - & - & - & - & [251] \\
\hline A & + & + & + & - & - & - & - & + & - & + & - & - & - & - & - & - & - & - & + & - & - & - & - & - & - & [252] \\
\hline $\mathrm{A}$ & + & + & + & - & - & - & - & - & - & - & - & - & - & - & - & - & - & + & - & - & - & - & - & - & - & [253] \\
\hline $\mathrm{A} \& \mathrm{MA}$ & - & + & - & - & - & - & - & - & - & - & - & - & - & - & - & - & - & - & - & - & - & - & - & - & - & [254] \\
\hline OPA & - & + & - & - & - & - & - & - & - & - & - & - & - & - & - & - & - & - & - & - & - & - & - & - & - & [255] \\
\hline MA \& OMA & + & - & + & - & - & + & - & - & - & - & - & - & - & - & - & - & + & - & - & - & - & - & - & - & - & [256] \\
\hline A & - & - & - & - & - & - & - & - & - & - & - & - & - & - & - & - & - & - & - & - & - & - & - & - & - & [257] \\
\hline A & + & - & - & - & - & - & - & - & - & - & - & - & - & - & - & + & - & - & - & - & - & - & - & - & - & {$[258]$} \\
\hline A & - & + & - & - & - & - & - & - & - & - & - & - & - & - & - & - & - & - & - & - & - & - & - & - & - & [259] \\
\hline A & + & - & - & - & - & - & - & - & - & - & - & - & - & - & - & - & - & - & - & - & - & - & - & - & - & [260] \\
\hline A & + & + & - & - & + & - & - & - & - & - & - & - & - & - & - & - & - & - & - & - & - & - & - & - & - & [261] \\
\hline A & + & - & - & - & - & - & - & - & - & - & - & - & - & - & - & - & - & + & - & - & - & - & - & - & - & [262] \\
\hline
\end{tabular}

Abbreviations: +, performed; -, not performed; A, aorta; AA, afferent arterioles; AT, angiotensin II; BA, basilar artery; BLA, bronchial artery; BRA, bone resistance artery;

CA, coronary artery; CBA, cerebral artery; CDA, caudal artery; CRA, carotid artery; D, denuded; ET, endothelin; FA, femoral artery; GA, gonadal artery; GCA, gracilis arterioles; GS, gallbladder strips; IA, iliac artery; IMA, internal mammary artery; MA, mesenteric artery; OMA, omental artery; OPA, ophthalmic artery; PA, pulmonary artery; PSA, prostatic small artery; R, receptor-operated calcium channels; RA, renal artery; RAS, retinal arterioles; RSA, resistance artery; S, store-operated calcium channels; SA, saphenous artery; $\mathrm{SE}$, Sacro/endoplasmic reticulum $\mathrm{Ca}^{2+}$-ATPase; SPA, splenic artery; Sr, serotonin; SV, saphenous vein; $\mathrm{T}$, thromboxane $\mathrm{A}_{2}$; TA, tail artery; TOV, type of vessel; UA, umbilical artery;

$\mathrm{V}$, voltage-operated calcium channels; VA, vertebrobasilar artery. 


\section{Signaling Mechanisms Involved in Vasodilation Studies}

The primary pathways involved in the vasodilation of blood vessels such as NO and COX are the most commonly used in the mechanism studies, since both of these pathways are well-studied EDRFs. They are subsequently followed by the potassium channels, which can be subdivided into $\mathrm{Kca}, \mathrm{K}_{\mathrm{ATP}}, \mathrm{Kv}$ and Kir, channels. Calcium channels are essentially involved in the regulation of vascular tone, hence $24 \%$ of the researches in vasodilation studies were conducted on it. It is also because calcium channels can be divided into a few groups. Some of the researches that have been done were focused on those groups separately, such as VOCC, ROCC, SOCC, as well as the SERCA signaling pathways. The signaling pathway studies on enzyme-linked receptors such as SGC come after the calcium channels, while few researches had been done on AC. Other than those, a few other mechanisms such as PKG, cAMP, PKA, M, 5-HT, ET-1, TxA 2 , AT, PKC, PDE, and $\alpha$ - and $\beta$-adrenergic receptors have been included in these studies as well.

\section{Endothelium-Derived Relaxing Factors (EDRFs)}

In vascular tone regulation, both endothelium-derived relaxing factors (EDRFs) and endothelium-derived contracting factors (EDCFs) produce their effect via interaction between the endothelium and vascular smooth muscle cells. The most well-studied EDRFs are nitric oxide (NO), which is produced by endothelial nitric oxide synthases (eNOS), and prostacyclin $\left(\mathrm{PGI}_{2}\right)$, produced by prostacyclin synthases within the endothelium [263-267].

\subsection{Nitric Oxide (NO)}

The highest percentage of the mechanism of actions summarized in Figure 1 belongs to the nitric oxide pathway at $72 \%$, which are 184 out of 257 of the researches on this pathway. Nitric oxide is produced by the endothelial nitric oxide synthase (eNOS) in the endothelium from the breakdown of L-arginine. Therefore, to determine whether the relaxation induced by the extract is by this pathway, the specific inhibitor most commonly used is $\mathrm{L}-\mathrm{N}^{\mathrm{G}}$-NitroArginineMethyl Ester (L-NAME), followed by $\mathrm{L}-\mathrm{N}^{\mathrm{G}}$-NitroArginine (L-NNA). L-NNA is the first synthetic NOS inhibitor which acts competitively and selectively to eNOS [268]. However, L-NNA was claimed to bind with different isoforms. The binding of L-NNA to eNOS and nNOS is a time-dependent process with a relatively slow reversal $[269,270]$. L-NNA can show excellent stability in aqueous environment and has low toxicity, but due to its poor solubility at neutral $\mathrm{pH}, \mathrm{L}-\mathrm{NAME}$ is preferable, even though it is a weak NOS inhibitor [271,272]. The bioactivation of the L-NAME proceeds at a moderate rate in physiological buffers, but it is markedly accelerated in blood or the vascular endothelium [273]. Eventually, the percentage of relaxation caused by the extract will be reduced in the presence of eNOS inhibitor if the action of the active compound is via this pathway.

\subsection{Prostacyclin $\left(\mathrm{PGI}_{2}\right)$}

The second most frequently-studied mechanism of action is the prostacyclin $\left(\mathrm{PGI}_{2}\right)$ signaling pathway (36\%), which comprised 92 out of the 257 of the articles reviewed. $\mathrm{PGI}_{2}$ is produced by prostacyclin synthase from the intermediate prostaglandin $\mathrm{H}_{2}$, which is derived from AA and catalyzed by COX. Typically, COX can be classified into two types of isoforms. COX 1 is claimed to be responsible for the synthesis of prostaglandin and thromboxane, whereas the inducible COX 2 plays an important role in the synthesis of prostaglandin for the inflammatory cells as well as in the central nervous system $[274,275]$. From the literature, the studies on this pathway were commonly conducted using non-steroidal anti-inflammatory drugs (NSAIDs) as COX inhibitors. The most commonly used was indomethacin, followed by ibuprofen, meclofenamic acid, and diclofenac. Indomethacin is a potent inhibitor of both COX 1 and COX 2 . However, there is an order of potency of the various inhibitors suggested, which is diclofenac $>$ indomethacin $>$ nimesulide $\approx$ meloxicam $\approx$ piroxicam [276]. Prostacyclin is one of the major relaxing factors derived from the endothelium. All the NSAIDs 
vary in their ability to inhibit both COX 1 and COX 2. Based on their mechanisms of inhibition, they can be classified into three broad categories. For instance, those that are able to bind reversibly and competitively to COX 1 and COX 2 are categorized in category 1 . These include mefenamic acid, piroxicam, and ibuprofen. Those with rapid lower-affinity reversible binding, followed by the time-dependent with higher-affinity and slow reversible binding to both COX 1 and COX 2, form the second category, examples of which include diclofenac, flubiprofen, and indomethacin. Lastly, those with rapid reversible binding followed by covalent modification of both COXs, such as aspirin, are classified into category $3[277,278]$. Therefore, if the tested compound exhibits its vasodilator effect through the synthesis of prostacyclin, its percentage of relaxation will be significantly decreased in the presence of a COX inhibitor.

\section{Enzyme-Linked NO pathway}

Soluble Guanylyl Cyclase (sGC)

In vascular tone regulation, the soluble type of guanylyl cyclase (sGC) is strictly related to the NO that diffuses into the adjacent VSMCs. Some of the researchers assumed that it is one of the pathways of NO/cGMP and 23\% (60 out of 257) of the research involved the study of this mechanism. Two types of inhibitors were utilized to study these mechanisms, which are methylene blue (MB) and $1 \mathrm{H}-[1,2,4]$ oxadiazolo $[4,3-a]$ quinoxalin-1-one (ODQ). MB was claimed to not be a true inhibitor of sGC. It can only act as a cGMP-lowering agent and partially prevents the nitrodilator-dependent activation of sGC by generating oxygen-free radicals. It has been described as a NO-release inhibitor [279] and does not enter the cells unless the membrane is permeabilized [280]. Therefore, MB is more appropriately used to determine the cGMP-dependent mechanism pathway since it is a non-selective inhibitor of sGC. However, the second type of inhibitor, ODQ, having an $\mathrm{IC}_{50}$ of around $20 \mathrm{nM}$, was claimed to be a non-reversible but more selective inhibitor to the sGC enzyme [281]. ODQ can be solubilized by using DMSO and has been widely used to differentiate cGMP-mediated effects of NO from cGMP-independent effects [282,283]. ODQ apparently inhibits sGC through oxidation on the heme group of the enzyme. In this case, if the test compound exerts its relaxant effect through stimulation of the sGC activity, it will have a lower vasodilation effect on the isolated tissue in the presence of the ODQ inhibitor. Nonetheless, if the test compound's relaxing effect is strictly dependent on the production of the cGMP, then the subsequent percentage of relaxation exerted on the isolated tissue will significantly decrease in the presence of methylene blue, or else it will remain unchanged in the presence of ODQ. A few studies (2\% or 6 out of the 257 papers) included research on the protein kinase G (PKG) mechanism pathway. The most commonly used cGMP-dependent PKG inhibitor (cGKI) is Rp-8-Br-PET-cGMPs. It is a metabolically stable, competitive, reversible, and non-selective blocker since it was claimed to be able to block both PKG 1 and PKG 2 [284].

\section{G-Protein-Coupled Receptors}

G-protein-coupled receptor (GPCR) is a single polypeptide that has seven transmembrane-spanning $\alpha$-helices. It will respond to ligands through the activation of the G-proteins, which are located on the intracellular surface of the cell membrane. In general, G-proteins can be categorized into $\alpha, \beta$, and $\gamma$ types. They are functionally switched on when bound to guanosine triphosphate (GTP) and will revert to resting state when they are bound to guanosine diphosphate (GDP) [285]. Once GTP is bound to the G-protein and activates it, the G-protein will be cleaved into $G \alpha$ and $G \beta \gamma$ dimers. Typically, $G \alpha$-proteins can be classified into $G_{\mathrm{q}} \alpha, G_{i} \alpha$, and $G_{s} \alpha$ which are functionally responsible for different roles in signaling transduction of blood vessels. $G_{q} \alpha$-protein tends to activate PLC- $\beta$ for increasing the production of the second messengers $I P_{3}$ and DAG, whereas $G_{i} \alpha$ is functionally opposed to $G_{q} \alpha$. Nonetheless, $\mathrm{G}_{\mathrm{s}} \alpha$-protein tends to activate adenylyl cyclase (AC) to increase the production of the cAMP second messenger, which is involved in the vasodilation pathway. In the endothelium, there are a few $G_{q} \alpha$-protein-coupled receptors such as angiotensin receptor $\left(\mathrm{AT}_{2}\right)[286-288]$, serotonin $\left(5-\mathrm{HT}_{1 \mathrm{D}}\right)$ 
receptor [289-292], bradykinin receptor $\left(B_{2}\right)$ [293,294], muscarinic receptor $\left(\mathrm{M}_{3}\right)$, and endothelin receptor $\left(\mathrm{ET}_{\mathrm{B}} \mathrm{R}\right)$ [295-299]. Whereas in the VSMC, the $\alpha_{1}$-adrenergic receptor [288,292], muscarinic receptor $\left(\mathrm{M}_{3}\right)$ [300-302], angiotensin receptor $\left(\mathrm{AT}_{1}\right)$ [286,303-306], endothelin receptor $\left(\mathrm{ET}_{\mathrm{A}} \mathrm{R}\right.$ \& $\left.\mathrm{ET}_{\mathrm{B}} \mathrm{R}\right)[292,295-299,307]$, serotonin receptor $\left(5-\mathrm{HT}_{2}\right)[289,290,292,308]$, and thromboxane receptor $\left(\mathrm{TxA}_{2}\right)[288,292,309]$, are $\mathrm{G}_{\mathrm{q}} \alpha$-protein-coupled receptors and tend to produce a direct effect in the increase of intracellular concentration of calcium by passing through the PLC-dependent pathway.

\section{1. $\beta$-Adrenergic Receptors}

Activation of the $G_{s} \alpha$-protein-coupled receptors, such as the $\beta_{2}$-adrenergic receptor and the IP receptor, will stimulate the activity of adenylyl cyclase (AC) in the VSMCs. These $G_{s} \alpha-P C R s$ have a less dominant presence in the VSMCs compared to $\mathrm{G}_{\mathrm{q}} \alpha$-PCRs, hence less research were conducted on these mechanisms. Of the studies, only $4 \%$ (11 out of 257 ) were on the AC pathway, $2 \%$ (5 out of 257) on the cAMP, and $2 \%$ (5 out of 257) on the cAMP-dependent protein kinase A (PKA) pathway. Due to the PKA's tetrameric composition in both catalytic and regulatory subunits, the inhibition of PKA can be achieved by blocking the ATP binding site or by inhibiting the analogue cAMP [310,311]. Generally, SQ22536 is more commonly utilized in vitro as an AC inhibitor, which is claimed to be more potent than MDL12330A. SQ22536 is specific to cAMP signaling and does not block the actions of other compounds that are not related to cAMP signaling [312]. SQ 22536 is cell-permeable and soluble in water. Other than that, Rp-cAMPs and H-89 have been used to study the cAMP and cAMP-dependent PKA mechanisms of action, respectively. Rp-cAMPs is a cell-permeable, reversible, competitive, and selective inhibitor for PKA. It is also resistant to the degradation of PDE, which makes it as an excellent tool to study these mechanisms [313]. H-89 is claimed to be a potent, cell-permeable, and reversible inhibitor of PKA, but it has been claimed that $\mathrm{H}-89$ will exhibit unwanted effects such as influencing the ion currents and contraction of the smooth muscle [314] and activation of the PKG pathway [315]. Due to the unclear metabolic fate of H-89 and another inhibitor KT-5720, Rp-cAMPs is generally recommended for studies on this mechanism. In this case, if the test compound has employed this pathway for the regulation of the vascular tone, the expected outcome of the vasodilation effect would be decreased in the presence of this inhibitor. In regard to this pathway, the $\beta_{2}$-adrenergic receptor, which is located on the VSMCs, actually employs this pathway for vasodilation as well. Only $8 \%$ (21 out of 257 studies) have focues onthis pathway. Even though its effect in the regulation of the vascular tone of blood vessels is not dominant, it is significant in myocytes. Propanolol is most widely used as the $\beta$-blocker in their studies. It is a non-selective blocker of the $\beta$-adrenergic receptor. Other than that, nadolol, atenolol, and pindolol have been used for these mechanistic studies as well. However, according to the classification of $\beta$-blockers, propanolol, nadolol, and pindolol are classified as non-selective $\beta$-blockers, whereas atenolol is more selective in cardio $\beta_{1}$-blockers [316]. Propanolol is preferable for the screening of isolated tissue as compared to cardio-selective $\beta$-blockers. If the test compound involves this pathway, the resulting vasodilation effect will be decreased in the presence of $\beta$-blockers.

\subsection{Muscarinic Receptors $\left(M_{3}\right)$}

There are five subgroups of muscarinic receptors, but only $\mathrm{M}_{3}$ receptors are present in the blood vessels. $\mathrm{M}_{3}$ receptors are $\mathrm{G}_{\mathrm{q}} \alpha$-protein-coupled receptors, predominant in the endothelial cells in which they mediate vasodilative effect through stimulating the cascade of signaling pathways within the endothelium. There are $\mathrm{M}_{3}$ receptor selective antagonists present in the market, such as $\mathrm{N}$-methylatropine and tiotropium, but evidence proves that $\mathrm{M}_{1}$ receptors are actually present in the endothelium [317]. However, that information still remains insufficient. Therefore, the non-selective muscarinic receptor atropine has been widely used to study this pathway, comprising approximately $8 \%$ (20 out of 257) of the studies. Atropine is a well-known muscarinic subtype non-specific antagonist, which acts as a competitive inhibitor with acetylcholine at the postganglionic muscarinic sites $[318,319]$. 
When atropine is bound to the $\mathrm{M}_{3}$ receptor, the subsequent vasodilation exerted by the test compound would be decreased significantly.

\section{Vasoconstriction-Dominated Receptors}

In studies about the mechanism pathways employed by test compounds causing vasodilation on isolated tissue, the mechanism of actions predominantly responsible for causing vasodilation should be well-determined This is especially true for eNOS, $\mathrm{PGI}_{2}$, sGC pathways, as well as their messengers produced. During these studies, researchers usually prioritize on enzymes and receptors which predominantly cause vasodilation upon their activation, such as eNOS, $\mathrm{PGI}_{2}, \mathrm{AC}, \mathrm{sGC}$, muscarinic receptors, and $\beta$-adrenoreceptors. This is because the vasodilation effect of the test substances should be dominating the effect of the vasoconstriction if the test substances in fact have a mild agonist effect on the vasoconstrictor-predominant receptors, such as serotonin receptors, $\mathrm{ET}_{\mathrm{A}} \mathrm{R}, \mathrm{ET}_{\mathrm{B}} \mathrm{R}, \mathrm{AT}-1$, PKC, $\alpha_{1}$-adrenoreceptors, and $\mathrm{T}_{\mathrm{X}} \mathrm{A}_{2}$ receptors. For instance, if the test substances have employed these signaling mechanism pathways, eventually they will result in vasoconstriction. Nonetheless, the test substances could act as blockers of these vasoconstriction-predominated receptors, which will cause more vasodilation. However, many of these mechanistic pathways might be included and need to add their effects to exhibit a major vasodilation effect. Therefore, most researchers did not conduct this type of mechanistic pathway studies since most of the results of each separate signaling mechanism study could be insignificant due to their minor contribution on the overall effect. From the articles, to determine the mechanism of action of the test compound, the percentage of relaxation in the experimental group where the antagonists have been applied before pre-contraction must be compared with the control group. However, from the data tabulation in Table 1, few studies have been conducted on the mechanism of action of vasoconstriction-dominated receptors. Those receptors, such as $\alpha_{1}$-adrenergic receptor $(4 \%)$, serotonin receptor $(1 \%)$, thromboxane receptor $(1 \%)$, angiotensin 2 receptor $(3 \%)$, and endothelin receptor $(1 \%)$, are functionally dominant in the VSMCs. All these receptors are $\mathrm{G}_{\mathrm{q}} \alpha$-protein-coupled receptors and tend to act in receptor-operated pathways to increase the calcium concentration in the cytosol when stimulated by their selective agonists. A selective blocker for $\alpha_{1}$-adrenergic receptor, prazosin, was the most commonly used test compound. There are two subtypes of endothelin receptors present in the VSMCs, BQ-123 and BQ-788, which have been used as selective blockers for $\mathrm{ET}_{\mathrm{A}} \mathrm{R}$ and $\mathrm{ET}_{\mathrm{B}} \mathrm{R}$ respectively. Besides, the angiotensin 2 type 1 receptor (AT-1) has been widely studied by using its specific antagonists, such as losartan and valsartan, whereas, the selective inhibitors for thromboxane receptor $\left(\mathrm{TxA}_{2}\right)$ and serotonin $\left(5-\mathrm{HT}_{2}\right)$ the compounds used were ridogrel and katanserin, respectively. Other than those, the protein kinase $C$ (PKC) and PDE enzymatic signaling pathways have also been studied using their respective inhibitors. For instance, the selective inhibitors of PKC commonly used are GF 109203X, staurosporine, Go 6983, chelerythrine, and highly-selective cell-permeable BIM. PDE present in the VSCMCs are commonly classified as PDE 5 and PDE 3. About 3\% of the papers involved studies on this pathway. Examples of selective inhibitors of PDE 5 are sildenafil, dipyridamole, zaprinast, and T-1032, while milrinone is a selective inhibitor for PDE 3. However, the non-selective PDE inhibitor papaverine has been utilized as well in their studies.

\section{Channel-Linked Receptors}

These receptors are also known as ligand-gated channels, whereby the channels respond by binding with chemical messengers and react by allowing the ions, such as calcium, potassium, sodium, chloride, or magnesium, to enter or leave the cell. Typically, the reaction of these receptors is regulated by the membrane potential. 


\subsection{Potassium Channels}

\subsubsection{Calcium-Dependent Potassium Channels (Kca)}

According to Table 1, thisis the 3rd most abundantly studied topic (30\%, 76 out of 257 papers) in the reviewed research. Kca channels consist of small-conductance (SKca), intermediate-conductance (IKca), and big-conductance calcium-activated potassium channels (BKca). SKca and IKca channels are more abundantly expressed in the endothelium, but expressed poorly in the VSMCs, hence it has been claimed they are able to contribute to the EDHF signals and react in the adjacent VSMCs [320-326], whereas the BKca channels are expressed in virtually all VSMCs. According to the analysis, the majority of the studies on this pathway have been conducted using the non-selective Kca channel blocker, tetraethylammonium ion (TEA). Even though TEA can completely abolish the delayed potassium channels current without affecting the transient sodium current [327], it is a non-selective Kca channel blocker. Therefore, to make the Kca channel signaling pathway clearer, SKca, IKca, and BKca channel blockers should be used to examine the Kca channel pathway mechanisms. Due to this reason, some of the researches were done by using different selective channel blockers. Blockers such as apamin were used as the SKca channel blocker, TRAM-34 and clotrimazole as selective blockers for IKca, and iberiotoxin, UCL 1684, and paxilline as the selective blockers for BKca channels [323]. A few of the researches have used charybdotoxin as a non-selective blocker to determine both BKca and IKca channels. Specific determination of both IKca and SKca channels is necessary due to their contribution as EDHF within the endothelium. Besides, both of these channels are functionally associated with calcium and calmodulin binding [328], and are indirectly involved in the regulation of vascular tone through their participation in generating membrane potential. The activation of the BKca channels are indirectly mediated by many of the second messengers such as PKA, PKG, and the nitric oxide that diffuse across the VSMC membrane. BKca channels are voltage and calcium concentration-dependent potassium channels, hence indicating their essential roles in controlling the vascular tone excitability. The vasodilation effect will be decreased in the presence of the BKca inhibitor since there is a high depolarizing voltage created on the VSMC membrane that can induce more influx of calcium ions into the cytosol and cause muscle contraction.

\subsubsection{ATP-Sensitive Potassium Channels $\left(\mathrm{K}_{\mathrm{ATP}}\right)$}

The second most frequently used channel in vasodilation research was ATP-sensitive potassium channels ( $\mathrm{K}_{\mathrm{ATP}}$ ), which were studied in $21 \%$ (54 out of 257 ) of the reports. This channel opens when the intracellular ATP concentration falls below $1 \mathrm{mmol} / \mathrm{L}$ [329,330]. Glibenclamide, a selective $\mathrm{K}_{\text {ATP }}$ channels blocker, is the only antagonist utilized by those researches to determine thismechanism of action [331]. A few endothelium-derived substances, such as calcitonin-gene related protein (CGRP) and hydrogen sulfide $\left(\mathrm{H}_{2} \mathrm{~S}\right)$, are able to stimulate $\mathrm{K}_{\text {ATP }}$ channels directly as well as indirectly mediated by cAMP-dependent PKA. The opening of these channels can cause membrane hyperpolarization, therefore the vasodilation effect will be decreased when the $\mathrm{K}_{\mathrm{ATP}}$ channel antagonists are present [330].

\subsubsection{Voltage-Dependent Potassium Channels (Kv) and Inwardly Rectifier Potassium Channels (Kir)}

There are two more potassium channels which are important based on their functional roles in the regulation of membrane potential, namely voltage-activated potassium channels $(\mathrm{Kv})$ and inwardly rectifier potassium channels (Kir), which have been studied in 14\% (37 out of 257) and 7\% (19 out of 257) of the studies, respectively. They are less significant when compared to Kca channels and $\mathrm{K}_{\mathrm{ATP}}$ channels because their functional roles are strictly regulated through the membrane potential. To determine the Kv channel pathway mechanisms, all the researchers used 4-aminopyridine (4-AP) as an antagonist and only one group used the $\mathrm{Kv}_{7}$ selective blocker to investigate this pathway. $\mathrm{Kv}$ channels consist of many different subgroups, therefore in order to inhibit these channels, a non-selective 4-AP blocker is preferable to using a selective inhibitor. It is an important component of 
the outward potassium conductance and is heavily regulated by kinases such as PKA, PKG and PKC, while sGC and NO tend to activate this channel directly [323]. These channels tend to provide the counterbalancing potassium efflux for the calcium influx through the voltage-operated calcium channel (VOCC) $[332,333]$. Therefore, if these channels were blocked, subsequent membrane depolarizing current will induce the calcium influx, resulting in more vasoconstriction. The Kir channels more readily induce the inward movement of potassium current and fasten the membrane potential to the resting stage [323]. Barium chloride $\left(\mathrm{BaCl}_{2}\right)$ is the Kir channel blocker that has been most used so far according to the tabulated data, and will cause the decrease in relaxation response if the test compound employed this pathway. Barium chloride can selectively block Kir channels [334].

\subsection{Calcium Channels}

\subsubsection{Voltage-Operated Calcium Channels (VOCC)}

Generally, there are three types of commonly-used selective L-type calcium channel blockers from the data obtained, which are the dihydropyridine class of nifedipine, the benzothiazepine class of diltiazem, and the phenylalkylamineclass of verapamil. These three classes of calcium channel blockers have different pharmacological effects due to the fact that they bind to different sites of the calcium channel. Diltiazem and verapamil have overlapping binding sites, whereas nifedipine binds to a distinct site. Therefore, the selectivity to the calcium channel blocker is arranged in ascending order as such nifedipine>diltiazem>verapamil, with the experiments executed using peripheral arterioles or coronary arteries [335]. However, verapamil is still the most widely-used calcium channel blocker in the studies. The dihydropyridines calcium channels blockers, such as nifedipine and nicardipine, have a higher vascular selectivity [336] and are the most smooth muscle selective class of the calcium channel blockers. From Table 1, 4\% (10 out of 257) of the studies were conducted regarding this calcium channel blocker. Two types of methods were implemented in the researches to determine the VOCC mechanism pathway. One of the methods is that isolated tissue was incubated with the calcium channel antagonist before pre-contraction, and subsequently the cumulative concentration of the test compound was added. In this case, if the test compound has the potential to act as a VOCC opener in their mechanism of action in controlling the vascular tone in the control set of experiment, then the resulting vasodilation should be increased in the second set of the experiments where the VOCC antagonist was applied. By using this method, the inference of whether the test compound has employed this pathway as its mechanism of action can be made, but is not practically used because the action potential would abolish the significance of the result achieved. Therefore, the second method was the choice of the majority of researchers, as it is more suitable to determine whether their test compound can be a potential blocker for the VOCC. Isolated tissue is incubated and washed with calcium-free Krebs-Henseleit solution, which contains ethylenediamine tetraacetic acid (EDTA) or ethylene glycol tetraacetic acid (EGTA) with high potassium content ( $50 \mathrm{mM})$. Both of them are chelating agents and appear as white crystalline powders, but EGTA is preferable because of its significantly higher affinity to the divalent calcium ions, while EDTA is preferable for divalent magnesium ions. The solution used to wash the isolated tissue should not contain any EGTA or EDTA. The tissue was then incubated with certain doses of the test compound for at least 10 min before adding cumulative doses of calcium chloride. The experimental group was compared to the control group (including the positive control) to determine the degree of significance. By using this method, if the contraction induced by the cumulative doses of calcium chloride is significantly decreased, this indicates that the test compound has potential to act as the antagonist of the VOCC.

\subsubsection{Store-Operated Calcium Channels (SOCC)}

Regarding the intracellular release of calcium from the sacroplasmic reticulum stores, gandolinium $\left(\mathrm{Gd}^{3+}\right)$ and 2-aminoethoxydiphenyl borate (2-APB) are most widely been used inhibitors to study this pathway. Around $2 \%$ of the researcher studied this pathway. 2 -APB is an $\mathrm{IP}_{3} \mathrm{R}$ inhibitor and is able to 
inhibit the release of the intracellular stores of calcium from SR. It was claimed to be able to completely inhibit the release of calcium at high concentrations $[337,338]$ and is also a reliable blocker of the SOCC, but an inconsistent inhibitor of $\mathrm{IP}_{3}$-induced calcium release [339]. Other than that, the $\mathrm{Gd}^{3+}$ is usually used together with the 2-APB as it is a selective blocker of the SOCC [340,341]. However, a few of the researchers were using non-competitive, selective, and cell-permeable SERCA blockers such as thapsigargin [342] to aid the calcium entry blocking effect from the SOCC into the SR during their studies on this mechanism of action. Like VOCC, two methods can be used to test this SOCC mechanism of action. The isolated tissue is pre-treated with the normal Krebs-Henseleit solution containing thapsigargin, $\mathrm{Gd}^{3+}$, as well as nifedipine to eliminate the VOCC effect for at least $10 \mathrm{~min}$ before the pre-contraction. Subsequently, cumulative doses of the test compound were added. If the test compound utilizes this pathway in its regulation of vascular tone, it will exhibit more relaxation than in the control group because the test compound can no longer induce the entry of calcium though the SOCC. However, another method is used to determine whether the calcium released from the sites of intracellular calcium store contributes to the auto-regulation of vascular tone. In this case, the isolated tissue was pre-treated with calcium-free Krebs-Henseleit solution containing the test compound for at least $20 \mathrm{~min}$ before the addition of phenylephrine. If there is a significant change in the percentage of contraction induced by $\mathrm{PE}$, this indicates that the test compound plays a role in controlling the intracellular release of calcium into the cytosol.

\section{List of Antagonists and Its Receptor}

All the antagonists used in their respective signaling mechanism pathway studies as tabulated in Table 1 were accordingly recategorized in Table 2 to facilitate future researchers in related pharmacological research fields.

\section{Conclusions}

Understanding the microenvironment of blood vessel in regard to its regulation of vascular tone is essential for those who work in research to develop a new anti-hypertensive drug. Nonetheless, during the discovery of new drugs, researchers should be able to confirm and elaborate the most appropriate types of antagonists used according to their selectivity, specificity, affinity, reversibility and solubility to test on potential anti-hypertensive test compounds as well as the procedures used in order to obtain a clear and firm inference about the pathways that the test compound has employed for inducing the vasodilation effect. In this review paper, the essential signaling mechanism pathways that were most frequently demonstrated in anti-hypertensive research have been summarized, as well as the expected outcome of the studies of test compounds that involve a particular mechanism pathway. In the future, a general picture of the blood vessel microenvironment in vascular tone regulation, including signals of second messengers and the interaction among receptors and enzymes, should be used as a whole to provide a general view for the researchers who will work on this topic. 
Table 2. General list of antagonists used in studies of signaling mechanism pathways according to their selectivity.

\begin{tabular}{|c|c|c|c|}
\hline Mechanism Pathways & Antagonists & Non-Selective & Ref. \\
\hline Endothelial nitric oxide synthase (eNOS) & L-N $\mathrm{N}^{\mathrm{G}}$-NitroArginine-Methyl Ester, L-N $\mathrm{N}^{\mathrm{G}}$-NitroArginine & & [268-273] \\
\hline Cyclooxygenase (COX) & & $\begin{array}{l}\text { Ibuprofen, mefenamic acid, piroxicam, } \\
\text { diclofenac, flubiprofen, indomethacin, aspirin }\end{array}$ & [276-278] \\
\hline Soluble guanylyl cycles (sGC) & $1 H$-[1,2,4] oxadiazolo [4,3-a]-quinoxalin-1-one & Methylene blue & {$[279,281-283]$} \\
\hline Protein kinase G (PKG) & KT 5823 & Rp-8-Br-PET-cGMPs & [284] \\
\hline Adenylyl cyclase (AC) & & SQ22536, MDL12330A, 2' '5'-dideoxyadenosine & [312] \\
\hline Protein kinase A (PKA) & Rp-cAMPs, KT 5720, H-89 & & [313-315] \\
\hline$\beta$-adrenergic receptor & Atenolol & Propanolol, nadolol, pindolol & [316] \\
\hline$\alpha$-adrenergic receptor & $\operatorname{Prazosin}\left(\alpha_{1}\right), \mathrm{RX} 821002\left(\alpha_{2}\right)$ & & {$[288,292]$} \\
\hline Endothelin receptor & $\mathrm{BQ} 123\left(\mathrm{ET}_{\mathrm{A}} \mathrm{R}\right), \mathrm{BQ} 788\left(\mathrm{ET}_{\mathrm{B}} \mathrm{R}\right)$ & Bosentan & [295-299] \\
\hline Angiotensin II receptor (AT1) & Candesartan cilexetil $\left(\mathrm{ARB} \& \mathrm{AT}_{1}\right)$, losartan $\left(\mathrm{AT}_{1}\right)$, valsartan $\left(\mathrm{ARB} \& \mathrm{AT}_{1}\right)$ & & {$[286-288,303-306]$} \\
\hline Muscarinic receptor & $N$-methylatropine, tiotropium & Atropine & {$[300-302,318,319]$} \\
\hline Thromboxane $\left(\mathrm{TxA}_{2}\right)$ & Ridogrel, ozagrel, furegrelate & & {$[288,292,309]$} \\
\hline Serotonin receptor $(\mathrm{Sr})$ & Katanserin $\left(5-\mathrm{HT}_{2}\right)$, WAY $100635\left(5-\mathrm{HT}_{1 \mathrm{~A}}\right)$ & & [289-292] \\
\hline Protein kinase C (PKC) & GF 109203x, staurosporine, Go 6983, chelerythrine, BIM & & [286-288] \\
\hline Phosphodiesterase (PDE) & $\begin{array}{l}\text { Slidenafil (PDE 5), dipyridamole (PDE 5), zaprinast (PDE 5), T } 1032 \text { (PDE 5), } \\
\text { rolipram (PDE 4), milrinone (PDE 3) }\end{array}$ & Papaverine & [152] \\
\hline Calcium-activated potassium channel (Kca) & $\begin{array}{c}\text { Iberiotoxin (BKca), UCL } 1684 \text { (BKca), paxilline (BKca), apamin (SKca), } \\
\text { TRAM-34 (IKca), clotrimazole (IKca) }\end{array}$ & Charybdotoxin (BKca \& IKca), TEA & {$[323,327,328]$} \\
\hline ATP-sensitive potassium channel $\left(\mathrm{K}_{\mathrm{ATP}}\right)$ & Glibenclamide & & {$[330,331]$} \\
\hline Voltage-activated potassium channel $\left(\mathrm{K}_{\mathrm{v}}\right)$ & XE $991\left(K_{V} 7\right)$ & 4-aminopyridine & {$[323,332,333]$} \\
\hline Inwardly-rectifier potassium channel $\left(\mathrm{K}_{\mathrm{ir}}\right)$ & & Barium chloride & [334] \\
\hline Voltage-operated calcium channel (VOCC) & Nifedipine, nicardipine, diltiazem & Verapamil & {$[335,336]$} \\
\hline Store-operated calcium channel (SOCC) & Gandolinium & & {$[340,341]$} \\
\hline Inositol triphosphate receptor $\left(\mathrm{IP}_{3} \mathrm{R}\right)$ & 2-Aminoethoxydiphenyl borate & & [337-341] \\
\hline SERCA & Thapsigargin, cyclopiazonic acid & & [342] \\
\hline
\end{tabular}


Acknowledgments: We extend the sincerest apologiesto any authorswhose work was not cited in this review. We would also like to thank those who have contributed their ideas in this topic. This review article was not supported by any grant.

Author Contributions: Y.C.L. prepared the manuscript; C.S.T. searched and reviewed published articles in PubMed; Y.S.C. recorded and analyzed data; M.A., M.Z.A. and M.F.Y. planned and coordinated.

Conflicts of Interest: The authors declare no conflict of interest.

\section{References}

1. Yang, Y.; Zhang, Z.; Li, S.; Ye, X.; Li, X.; He, K. Synergy effects of herb extracts: pharmacokinetics and pharmacodynamic basis. Fitoterapia 2014, 92, 133-147. [CrossRef] [PubMed]

2. Lenfant, C.; Chobanian, A.V.; Jones, D.W.; Roccella, E.J. Seventh report of the Joint National Committee on the Prevention, Detection, Evaluation, and Treatment of High Blood Pressure (JNC 7): resetting the hypertension sails. Hypertension 2003, 41, 1178-1179. [CrossRef] [PubMed]

3. Whalen, K. Lippincott Illustrated Reviews: Pharmacology, 6th ed.; Lippincott Williams \& Wilkins: Philadelphia, PA, USA, 2014; pp. 225-240.

4. Yildiz, O.; Gul, H.; Seyrek, M. Pharmacology of Arterial Grafts for Coronary Artery Bypass Surgery; Intech Open Access Publisher: Rijeka, Croatia, 2013.

5. Rameshrad, M.; Babaei, H.; Azarmi, Y.; Fouladia, D.F. Rat aorta as a pharmacological tool for in vitro and in vivo studies. Life Sci. 2016, 145, 190-204. [CrossRef] [PubMed]

6. Ameer, O.Z.; Salman, I.M.; Siddiqui, M.J.; Yam, M.F.; Sriramaneni, R.N.; Mohamed, A.J.; Sadikun, A.; Ismail, Z.; Shah, A.M.; Asmawi, M.Z. Pharmacological mechanisms underlying the vascular activities of Loranthus ferrugineus Roxb. in rat thoracic aorta. J. Ethnopharmacol. 2010, 127, 19-25. [CrossRef] [PubMed]

7. Li, R.W.; Yang, C.; Shan, L.; Zhang, Z.; Wang, Y.; Kwan, Y.W.; Lee, S.M.; Hoi, M.P.; Chan, S.W.; Cheung, A.C.; et al. Relaxation effect of a novel Danshensu/tetramethylpyrazine derivative on rat mesenteric arteries. Eur. J. Pharmacol. 2015, 761, 153-160. [CrossRef] [PubMed]

8. Tsao, C.M.; Chen, S.J.; Tsou, M.Y.; Wu, C.C. Effect of propofol on vascular reactivity in thoracic aortas from rats with endotoxemia. J. Chin. Med. Assoc. 2012, 75, 262-268. [CrossRef] [PubMed]

9. Davis, B.; Rahman, A.; Arner, A. AMP-activated kinase relaxes agonist induced contractions in the mouse aorta via effects on PKC signaling and inhibits NO-induced relaxation. Eur. J. Pharmacol. 2012, 695, 88-95. [CrossRef] [PubMed]

10. Csanyi, G.; Gajda, M.; Franczyk-Zarow, M.; Kostogrys, R.; Gwozdz, P.; Mateuszuk, L.; Sternak, M.; Wojcik, L.; Zalewska, T.; Walski, M.; et al. Functional alterations in endothelial NO, PGI(2) and EDHF pathways in aorta in ApoE/LDLR-/- mice. Prostaglandins Other Lipid Mediat. 2012, 98, 107-115. [CrossRef] [PubMed]

11. Kim, E.Y.; Lee, Y.J.; Rhyu, M.R. Black cohosh (Cimicifuga racemosa) relaxes the isolated rat thoracic aorta through endothelium-dependent and -independent mechanisms. J. Ethnopharmacol. 2011, 138, 537-542. [CrossRef] [PubMed]

12. Gutierrez-Hernandez, J.M.; Ramirez-Lee, M.A.; Rosas-Hernandez, H.; Salazar-Garcia, S.; Maldonado-Ortega, D.A.; Gonzalez, F.J.; Gonzalez, C. Single-walled carbon nanotubes (SWCNTs) induce vasodilation in isolated rat aortic rings. Toxicol. In Vitro 2015, 29, 657-662. [CrossRef] [PubMed]

13. Capettini, L.S.; Cortes, S.F.; Lemos, V.S. Relative contribution of eNOS and nNOS to endothelium-dependent vasodilation in the mouse aorta. Eur. J. Pharmacol. 2010, 643, 260-266. [CrossRef] [PubMed]

14. Choi, S.; Kim, H.I.; Park, S.H.; Lee, M.J.; Jun, J.Y.; Kim, H.L.; Chung, J.H.; Yeum, C.H. Endothelium-dependent vasodilation by ferulic acid in aorta from chronic renal hypertensive rats. Kidney Res. Clin. Pract. 2012, 31, 227-233. [CrossRef] [PubMed]

15. Ziberna, L.; Lunder, M.; Tramer, F.; Drevensek, G.; Passamonti, S. The endothelial plasma membrane transporter bilitranslocase mediates rat aortic vasodilation induced by anthocyanins. Nutr. Metab. Cardiovasc. Dis. 2013, 23, 68-74. [CrossRef] [PubMed]

16. Koon, C.M.; Fong, S.; Wat, E.; Wang, Y.P.; Wing-Shing Cheung, D.; Bik-San Lau, C.; Leung, P.C.; Sun, H.D.; Zhao, Q.S.; Fung, K.P. Mechanisms of the dilator action of the Erigerontis Herba on rat aorta. J. Ethnopharmacol. 2014, 155, 1561-1567. [CrossRef] [PubMed] 
17. Bertin, R.; Chen, Z.; Martinez-Vazquez, M.; Garcia-Argaez, A.; Froldi, G. Vasodilation and radical-scavenging activity of imperatorin and selected coumarinic and flavonoid compounds from genus Casimiroa. Phytomedicine 2014, 21, 586-594. [CrossRef] [PubMed]

18. Lindsey, S.H.; Liu, L.; Chappell, M.C. Vasodilation by GPER in mesenteric arteries involves both endothelial nitric oxide and smooth muscle cAMP signaling. Steroids 2014, 81, 99-102. [CrossRef] [PubMed]

19. Shou, Q.; Pan, Y.; Xu, X.; Xu, J.; Wang, D.; Ling, Y.; Chen, M. Salvianolic acid B possesses vasodilation potential through NO and its related signals in rabbit thoracic aortic rings. Eur. J. Pharmacol. 2012, 697, 81-87. [CrossRef] [PubMed]

20. Cordeiro, B.; Shinn, C.; Sellke, F.W.; Clements, R.T. Rottlerin-induced BKCa channel activation impairs specific contractile responses and promotes vasodilation. Ann. Thorac. Surg. 2015, 99, 626-634. [CrossRef] [PubMed]

21. Yamawaki, H.; Tsubaki, N.; Mukohda, M.; Okada, M.; Hara, Y. Omentin, a novel adipokine, induces vasodilation in rat isolated blood vessels. Biochem. Biophys. Res. Commun. 2010, 393, 668-672. [CrossRef] [PubMed]

22. Xu, Z.; Wang, X.; Dai, Y.; Kong, L.; Wang, F.; Xu, H.; Lu, D.; Song, J.; Hou, Z. (+/-)-Praeruptorin A enantiomers exert distinct relaxant effects on isolated rat aorta rings dependent on endothelium and nitric oxide synthesis. Chem. Biol. Interact. 2010, 186, 239-246. [CrossRef] [PubMed]

23. Celotto, A.C.; Restini, C.B.; Capellini, V.K.; Bendhack, L.M.; Evora, P.R. Acidosis induces relaxation mediated by nitric oxide and potassium channels in rat thoracic aorta. Eur. J. Pharmacol. 2011, 656, 88-93. [CrossRef] [PubMed]

24. Mori, A.; Suzuki, S.; Sakamoto, K.; Nakahara, T.; Ishii, K. Vasodilation of retinal arterioles induced by activation of BKCa channels is attenuated in diabetic rats. Eur. J. Pharmacol. 2011, 669, 94-99. [CrossRef] [PubMed]

25. Tsounapi, P.; Saito, M.; Kitatani, K.; Dimitriadis, F.; Ohmasa, F.; Shimizu, S.; Kinoshita, Y.; Takenaka, A.; Satoh, K. Fasudil improves the endothelial dysfunction in the aorta of spontaneously hypertensive rats. Eur. J. Pharmacol. 2012, 691, 182-189. [CrossRef] [PubMed]

26. Silva, B.R.; Pernomian, L.; Grando, M.D.; Amaral, J.H.; Tanus-Santos, J.E.; Bendhack, L.M. Hydrogen peroxide modulates phenylephrine-induced contractile response in renal hypertensive rat aorta. Eur. J. Pharmacol. 2013, 721, 193-200. [CrossRef] [PubMed]

27. Silva, B.R.; Pernomian, L.; Grando, M.D.; Bendhack, L.M. Phenylephrine activates eNOS Ser 1177 phosphorylation and nitric oxide signaling in renal hypertensive rat aorta. Eur. J. Pharmacol. 2014, 738, 192-199. [CrossRef] [PubMed]

28. Nakabayashi, S.; Nagaoka, T.; Tani, T.; Sogawa, K.; Hein, T.W.; Kuo, L.; Yoshida, A. Retinal arteriolar responses to acute severe elevation in systemic blood pressure in cats: Role of endothelium-derived factors. Exp. Eye Res. 2012, 103, 63-70. [CrossRef] [PubMed]

29. Guven, G.; Seyrek, M.; Vural, I.M.; Cehreli, Z.C.; Yildiz, O. Vasodilatory effect of hydroxyethyl methacrylate and triethylene glycol dimethacrylate in rat aorta through calcium antagonistic action. J. Endod. 2011, 37, 353-357. [CrossRef] [PubMed]

30. Li, H.; Hong da, H.; Son, Y.K.; Na, S.H.; Jung, W.K.; Bae, Y.M.; Seo, E.Y.; Kim, S.J.; Choi, I.W.; Park, W.S. Cilostazol induces vasodilation through the activation of $\mathrm{Ca}^{2+}$-activated $\mathrm{K}^{+}$channels in aortic smooth muscle. Vascul. Pharmacol. 2015, 70, 15-22. [CrossRef] [PubMed]

31. Kamkaew, N.; Scholfield, C.N.; Ingkaninan, K.; Maneesai, P.; Parkington, H.C.; Tare, M.; Chootip, K. Bacopa monnieri and its constituents is hypotensive in anaesthetized rats and vasodilator in various artery types. J. Ethnopharmacol. 2011, 137, 790-795. [CrossRef] [PubMed]

32. Ng, C.F.; Koon, C.M.; Cheung, D.W.; Lam, M.Y.; Leung, P.C.; Lau, C.B.; Fung, K.P. The anti-hypertensive effect of Danshen (Salvia miltiorrhiza) and Gegen (Pueraria lobata) formula in rats and its underlying mechanisms of vasorelaxation. J. Ethnopharmacol. 2011, 137, 1366-1372. [CrossRef] [PubMed]

33. Jin, S.N.; Wen, J.F.; Wang, T.T.; Kang, D.G.; Lee, H.S.; Cho, K.W. Vasodilatory effects of ethanol extract of Radix Paeoniae Rubra and its mechanism of action in the rat aorta. J. Ethnopharmacol. 2012, 142, 188-193. [CrossRef] [PubMed]

34. Qu, Z.; Zhang, J.; Gao, W.; Chen, H.; Guo, H.; Wang, T.; Li, H.; Liu, C. Vasorelaxant effects of Cerebralcare Granule ${ }^{\circledR}$ are mediated by NO/cGMP pathway, potassium channel opening and calcium channel blockade in isolated rat thoracic aorta. J. Ethnopharmacol. 2014, 155, 572-579. [CrossRef] [PubMed] 
35. Hu, F.; Koon, C.M.; Chan, J.Y.; Lau, K.M.; Kwan, Y.W.; Fung, K.P. Involvements of calcium channel and potassium channel in Danshen and Gegen decoction induced vasodilation in porcine coronary LAD artery. Phytomedicine 2012, 19, 1051-1058. [CrossRef] [PubMed]

36. Chen, H.; Li, S.; Wang, P.; Yan, S.; Hu, L.; Pan, X.; Yang, C.; Leung, G.P. Endothelium-dependent and -independent relaxation of rat aorta induced by extract of Schizophyllum commune. Phytomedicine 2014, 21, 1230-1236. [CrossRef] [PubMed]

37. Khanna, V.; Jain, M.; Barthwal, M.K.; Kalita, D.; Boruah, J.J.; Das, S.P.; Islam, N.S.; Ramasarma, T.; Dikshit, M. Vasomodulatory effect of novel peroxovanadate compounds on rat aorta: Role of rho kinase and nitric oxide/cGMP pathway. Pharmacol. Res. 2011, 64, 274-282. [CrossRef] [PubMed]

38. Cameron, M.S.; Nobata, S.; Takei, Y.; Donald, J.A. Vasodilatory effects of homologous adrenomedullin 2 and adrenomedullin 5 on isolated blood vessels of two species of eel. Comp. Biochem. Physiol. A Mol. Integr. Physiol. 2015, 179, 157-163. [CrossRef] [PubMed]

39. Tom, E.N.; Girard, C.; Dimo, T.; Mbafor, J.T.; Berthelot, A.; Demougeot, C. Vasorelaxant effects of extracts of the stem bark of Terminalia superba Engler \& Diels (Combretaceae). J. Ethnopharmacol. 2010, 127, 335-340. [PubMed]

40. Neubauer, R.; Wolkart, G.; Opelt, M.; Schwarzenegger, C.; Hofinger, M.; Neubauer, A.; Kollau, A.; Schmidt, K.; Schrammel, A.; Mayer, B. Aldehyde dehydrogenase-independent bioactivation of nitroglycerin in porcine and bovine blood vessels. Biochem. Pharmacol. 2015, 93, 440-448. [CrossRef] [PubMed]

41. Ok, S.H.; Kwon, S.C.; Yeol Han, J.; Yu, J.; Shin, I.W.; Lee, H.K.; Chung, Y.K.; Choi, M.J.; Sohn, J.T. Mepivacaine-induced contraction involves increased calcium sensitization mediated via Rho kinase and protein kinase C in endothelium-denuded rat aorta. Eur. J. Pharmacol. 2014, 723, 185-193. [CrossRef] [PubMed]

42. Taguchi, K.; Matsumoto, T.; Kamata, K.; Kobayashi, T. Angiotensin II type 2 receptor-dependent increase in nitric oxide synthase activity in the endothelium of $\mathrm{db} / \mathrm{db}$ mice is mediated via a MEK pathway. Pharmacol. Res. 2012, 66, 41-50. [CrossRef] [PubMed]

43. Machado, N.T.; Maciel, P.M.; Alustau, M.C.; Queiroz, T.M.; Furtado, F.F.; Assis, V.L.; Veras, R.C.; Araújo, I.G.; Athayde-Filho, P.F.; Medeiros, I.A. Nitric oxide as a target for the hypotensive and vasorelaxing effects induced by (Z)-ethyl 12-nitrooxy-octadec-9-enoate in rats. Eur. J. Pharm. Sci. 2014, 62, 317-325. [CrossRef] [PubMed]

44. Celotto, A.C.; Capellini, V.K.; Restini, C.B.; Baldo, C.F.; Bendhack, L.M.; Evora, P.R. Extracellular alkalinization induces endothelium-derived nitric oxide dependent relaxation in rat thoracic aorta. Nitric Oxide 2010, 23, 269-274. [CrossRef] [PubMed]

45. Bonaventura, D.; de Lima, R.G.; da Silva, R.S.; Bendhack, L.M. NO donors-relaxation is impaired in aorta from hypertensive rats due to a reduced involvement of $\mathrm{K}^{+}$channels and sarcoplasmic reticulum $\mathrm{Ca}^{2+}$-ATPase. Life Sci. 2011, 89, 595-602. [CrossRef] [PubMed]

46. Senejoux, F.; Girard, C.; Aisa, H.A.; Bakri, M.; Kerram, P.; Berthelot, A.; Bevalot, F.; Demougeot, C. Vasorelaxant and hypotensive effects of a hydroalcoholic extract from the fruits of Nitraria sibirica Pall. (Nitrariaceae). J. Ethnopharmacol. 2012, 141, 629-634. [CrossRef] [PubMed]

47. Leo, C.; Joshi, A.; Hart, J.; Woodman, O. Endothelium-dependent nitroxyl-mediated relaxation is resistant to superoxide anion scavenging and preserved in diabetic rat aorta. Pharmacol. Res. 2012, 66, 383-391. [CrossRef] [PubMed]

48. Perusquia, M.; Espinoza, J.; de la Pena, A. Mifepristone (RU 486) induces vasodilation and inhibits platelet aggregation: nongenomic and genomic action to cause hemorrhage. Contraception 2011, 84, 169-177. [CrossRef] [PubMed]

49. Leal, C.M.; Pereira, S.L.; Kummerle, A.E.; Leal, D.M.; Tesch, R.; de Sant'Anna, C.M.; Fraga, C.A.; Barreiro, E.J.; Sudo, R.T.; Zapata-Sudo, G. Antihypertensive profile of 2-thienyl-3,4-methylenedioxybenzoylhydrazone is mediated by activation of the A2A adenosine receptor. Eur. J. Med. Chem. 2012, 55, 49-57. [CrossRef] [PubMed]

50. Zhang, Y.; Zhang, W.; Edvinsson, L.; Xu, C.B. Apolipoprotein B of low-density lipoprotein impairs nitric oxide-mediated endothelium-dependent relaxation in rat mesenteric arteries. Eur. J. Pharmacol. 2014, 725, 10-17. [CrossRef] [PubMed] 
51. Nakashima, M.; Shigekuni, Y.; Obi, T.; Shiraishi, M.; Miyamoto, A.; Yamasaki, H.; Etoh, T.; Iwai, S. Nitric oxide-dependent hypotensive effects of wax gourd juice. J. Ethnopharmacol. 2011, 138, 404-407. [CrossRef] [PubMed]

52. Rios, M.Y.; López-Martínez, S.; López-Vallejo, F.; Medina-Franco, J.L.; Villalobos-Molina, R.; Ibarra-Barajas, M.; Navarrete-Vazquez, G.; Hidalgo-Figueroa, S.; Hernández-Abreu, O.; Estrada-Soto, S. Vasorelaxant activity of some structurally related triterpenic acids from Phoradendron reichenbachianum (Viscaceae) mainly by NO production: Ex vivo and in silico studies. Fitoterapia 2012, 83, 1023-1029. [CrossRef] [PubMed]

53. Jerez, S.; Sierra, L.; Scacchi, F.; Peral de Bruno, M. Hypercholesterolemia modifies angiotensin II desensitisation and cross talk between $\alpha_{1}$-adrenoceptor and angiotensin $\mathrm{AT}(1)$ receptor in rabbit aorta. Eur. J. Pharmacol. 2010, 635, 149-155. [CrossRef] [PubMed]

54. Pagan, R.M.; Prieto, D.; Hernandez, M.; Correa, C.; Garcia-Sacristan, A.; Benedito, S.; Martinez, A.C. Regulation of NO-dependent acetylcholine relaxation by $\mathrm{K}^{+}$channels and the $\mathrm{Na}^{+}-\mathrm{K}^{+}$ATPase pump in porcine internal mammary artery. Eur. J. Pharmacol. 2010, 641, 61-66. [CrossRef] [PubMed]

55. Sauvaget, F.; Mallem, M.Y.; Bucas, V.; Gogny, M.; Desfontis, J.-C.; Noireaud, J. Positive influence of AT 1 receptor antagonism upon the impaired celiprolol-induced vasodilatation in aorta from spontaneously hypertensive rats. Eur. J. Pharmacol. 2010, 644, 169-175. [CrossRef] [PubMed]

56. Shim, H.S.; Ok, S.H.; Lee, S.H.; Kwon, S.C.; Sohn, J.T. Protein kinases participate in the contraction in response to levobupivacaine in the rat aorta. Eur. J. Pharmacol. 2012, 677, 131-137. [CrossRef] [PubMed]

57. Novakovic, A.; Marinko, M.; Vranic, A.; Jankovic, G.; Milojevic, P.; Stojanovic, I.; Nenezic, D.; Ugresic, N.; Kanjuh, V.; Yang, Q.; et al. Mechanisms underlying the vasorelaxation of human internal mammary artery induced by (-)-epicatechin. Eur. J. Pharmacol. 2015, 762, 306-312. [CrossRef] [PubMed]

58. Li, X.; Chen, G.P.; Li, L.; Wang, K.J.; Zhang, B.Q.; Hu, S.J. Dual effects of sodium aescinate on vascular tension in rat thoracic aorta. Microvasc. Res. 2010, 79, 63-69. [CrossRef] [PubMed]

59. Han, L.; Yu, Y.; Sun, X.; Wang, B. Exendin-4 directly improves endothelial dysfunction in isolated aortas from obese rats through the cAMP or AMPK-eNOS pathways. Diabetes Res. Clin. Pract. 2012, 97, 453-460. [CrossRef] [PubMed]

60. Rodrigues, S.M.; Ximenes, C.F.; de Batista, P.R.; Simoes, F.V.; Coser, P.H.; Sena, G.C.; Podratz, P.L.; de Souza, L.N.; Vassallo, D.V.; Graceli, J.B.; et al. Tributyltin contributes in reducing the vascular reactivity to phenylephrine in isolated aortic rings from female rats. Toxicol. Lett. 2014, 225, 378-385. [CrossRef] [PubMed]

61. Bankar, G.R.; Nayak, P.G.; Bansal, P.; Paul, P.; Pai, K.S.; Singla, R.K.; Bhat, V.G. Vasorelaxant and antihypertensive effect of Cocos nucifera Linn. endocarp on isolated rat thoracic aorta and DOCA salt-induced hypertensive rats. J. Ethnopharmacol. 2011, 134, 50-54. [CrossRef] [PubMed]

62. Hao, H.F.; Liu, L.M.; Liu, Y.Y.; Liu, J.; Yan, L.; Pan, C.S.; Wang, M.X.; Wang, C.S.; Fan, J.Y.; Gao, Y.S.; et al. Inhibitory effect of rhynchophylline on contraction of cerebral arterioles to endothelin 1: role of rho kinase. J. Ethnopharmacol. 2014, 155, 147-153. [CrossRef] [PubMed]

63. Tao, L.; Hu, H.S.; Shen, X.C. Endothelium-dependent vasodilatation effects of the essential oil from Fructus alpiniae zerumbet (EOFAZ) on rat thoracic aortic rings in vitro. Phytomedicine 2013, 20, 387-393. [CrossRef] [PubMed]

64. Kalea, A.Z.; Clark, K.; Schuschke, D.A.; Kristo, A.S.; Klimis-Zacas, D.J. Dietary enrichment with wild blueberries (Vaccinium angustifolium) affects the vascular reactivity in the aorta of young spontaneously hypertensive rats. J. Nutr. Biochem. 2010, 21, 14-22. [CrossRef] [PubMed]

65. Wu, J.H.; Li, Q.; Wu, M.Y.; Guo, D.J.; Chen, H.L.; Chen, S.L.; Seto, S.W.; Au, A.L.; Poon, C.C.; Leung, G.P.; et al. Formononetin, an isoflavone, relaxes rat isolated aorta through endothelium-dependent and endothelium-independent pathways. J. Nutr. Biochem. 2010, 21, 613-620. [CrossRef] [PubMed]

66. Lin, A.H.; Leung, G.P.; Leung, S.W.; Vanhoutte, P.M.; Man, R.Y. Genistein enhances relaxation of the spontaneously hypertensive rat aorta by transactivation of epidermal growth factor receptor following binding to membrane estrogen receptors- $\alpha$ and activation of a $G$ protein-coupled, endothelial nitric oxide synthase-dependent pathway. Pharmacol. Res. 2011, 63, 181-189. [PubMed]

67. Zhang, Y.; Chen, Q.; Sun, Z.; Han, J.; Wang, L.; Zheng, L. Impaired capsaicin-induced relaxation in diabetic mesenteric arteries. J. Diabetes Complications 2015, 29, 747-754. [CrossRef] [PubMed]

68. Wang, H.P.; Lu, J.F.; Zhang, G.L.; Li, X.Y.; Peng, H.Y.; Lu, Y.; Zhao, L.; Ye, Z.G.; Bruce, I.C.; Xia, Q.; et al. Endothelium-dependent and -independent vasorelaxant actions and mechanisms induced by total flavonoids of Elsholtzia splendens in rat aortas. Environ. Toxicol. Pharmacol. 2014, 38, 453-459. [CrossRef] [PubMed] 
69. Li, Y.J.; Bao, J.X.; Xu, J.W.; Murad, F.; Bian, K. Vascular dilation by paeonol-A mechanism study. Vascul. Pharmacol. 2010, 53, 169-176. [CrossRef] [PubMed]

70. Perez, T.; Lopez, R.M.; Lopez, P.; Castillo, C.; Castillo, E.F. Lack of heterologous receptor desensitization induced by angiotensin II type 1 receptor activation in isolated normal rat thoracic aorta. Vascul. Pharmacol. 2011, 54, 29-35. [CrossRef] [PubMed]

71. Chen, Y.J.; Wang, L.; Zhou, G.Y.; Yu, X.L.; Zhang, Y.H.; Hu, N.; Li, Q.Q.; Chen, C.; Qing, C.; Liu, Y.T.; et al Scutellarin attenuates endothelium-dependent aasodilation impairment induced by hypoxia reoxygenation, through regulating the PKG signaling pathway in rat coronary artery. Chin. J. Nat. Med. 2015, 13, 264-273. [CrossRef]

72. Araujo, A.V.; Ferezin, C.Z.; Rodrigues, G.J.; Lunardi, C.N.; Vercesi, J.A.; Grando, M.D.; Bonaventura, D.; Bendhack, L.M. Prostacyclin, not only nitric oxide, is a mediator of the vasorelaxation induced by acetylcholine in aortas from rats submitted to cecal ligation and perforation (CLP). Vascul. Pharmacol. 2011, 54, 44-51. [CrossRef] [PubMed]

73. Shen, M.; Zhao, L.; Wu, R.X.; Yue, S.Q.; Pei, J.M. The vasorelaxing effect of resveratrol on abdominal aorta from rats and its underlying mechanisms. Vascul. Pharmacol. 2013, 58, 64-70. [CrossRef] [PubMed]

74. Lee, K.Y.; Choi, H.C. Acetylcholine-induced AMP-activated protein kinase activation attenuates vasoconstriction through an LKB1-dependent mechanism in rat aorta. Vascul. Pharmacol. 2013, 59, 96-102. [CrossRef] [PubMed]

75. Perez-Aso, M.; Flacco, N.; Carpena, N.; Montesinos, M.C.; D'Ocon, P.; Ivorra, M.D. $\beta$-Adrenoceptors differentially regulate vascular tone and angiogenesis of rat aorta via ERK1/2 and p38. Vascul. Pharmacol. 2014, 61, 80-89. [CrossRef] [PubMed]

76. Bhattacharya, I.; Damjanovic, M.; Dominguez, A.P.; Haas, E. Inhibition of activated ERK1/2 and JNKs improves vascular function in mouse aortae in the absence of nitric oxide. Eur. J. Pharmacol. 2011, 658, $22-27$. [CrossRef] [PubMed]

77. El-Gowelli, H.M.; El-Gowilly, S.M.; Elsalakawy, L.K.; El-Mas, M.M. Nitric oxide synthase/K ${ }^{+}$channel cascade triggers the adenosine $\mathrm{A}_{2 \mathrm{~B}}$ receptor-sensitive renal vasodilation in female rats. Eur. J. Pharmacol. 2013, 702, 116-125. [CrossRef] [PubMed]

78. Sun, X.; Hou, N.; Han, F.; Guo, Y.; Hui, Z.; Du, G.; Zhang, Y. Effect of high free fatty acids on the anti-contractile response of perivascular adipose tissue in rat aorta. J. Mol. Cell. Cardiol. 2013, 63, 169-174. [CrossRef] [PubMed]

79. Gallo, L.C.; Davel, A.P.; Xavier, F.E.; Rossoni, L.V. Time-dependent increases in ouabain-sensitive $\mathrm{Na}^{+}$, $\mathrm{K}^{+}$-ATPase activity in aortas from diabetic rats: The role of prostanoids and protein kinase C. Life Sci. 2010, 87, 302-308. [CrossRef] [PubMed]

80. Horta, C.; Rezende, B.; Oliveira-Mendes, B.; Carmo, A.; Capettini, L.; Silva, J.; Gomes, M.; Chávez-Olórtegui, C.; Bravo, C.; Lemos, V. ADP is a vasodilator component from Lasiodora sp. mygalomorph spider venom. Toxicon 2013, 72, 102-112. [CrossRef] [PubMed]

81. Taguchi, K.; Kobayashi, T.; Takenouchi, Y.; Matsumoto, T.; Kamata, K. Angiotensin II causes endothelial dysfunction via the GRK2/Akt/eNOS pathway in aortas from a murine type 2 diabetic model. Pharmacol. Res. 2011, 64, 535-546. [CrossRef] [PubMed]

82. Jin, S.N.; Wen, J.F.; Li, X.; Kang, D.G.; Lee, H.S.; Cho, K.W. The mechanism of vasorelaxation induced by ethanol extract of Sophora flavescens in rat aorta. J. Ethnopharmacol. 2011, 137, 547-552. [CrossRef] [PubMed]

83. Gaete, P.S.; Lillo, M.A.; Ardiles, N.M.; Perez, F.R.; Figueroa, X.F. Ca ${ }^{2+}$-activated $\mathrm{K}^{+}$channels of small and intermediate conductance control eNOS activation through NAD $(\mathrm{P}) \mathrm{H}$ oxidase. Free Radic. Biol. Med. 2012, 52, 860-870. [CrossRef] [PubMed]

84. Silveira, E.A.; Siman, F.D.; de Oliveira Faria, T.; Vescovi, M.V.; Furieri, L.B.; Lizardo, J.H.; Stefanon, I.; Padilha, A.S.; Vassallo, D.V. Low-dose chronic lead exposure increases systolic arterial pressure and vascular reactivity of rat aortas. Free Radic. Biol. Med. 2014, 67, 366-376. [CrossRef] [PubMed]

85. Dongmo, A.B.; Nkeng-Efouet, P.A.; Devkota, K.P.; Wegener, J.W.; Sewald, N.; Wagner, H.; Vierling, W. Tetra-acetylajugasterone a new constituent of Vitex cienkowskii with vasorelaxant activity. Phytomedicine 2014, 21, 787-792. [CrossRef] [PubMed]

86. Zhou, Z.; Sun, C.; Tilley, S.L.; Mustafa, S.J. Mechanisms underlying uridine adenosine tetraphosphate-induced vascular contraction in mouse aorta: Role of thromboxane and purinergic receptors. Vascul. Pharmacol. 2015, 73, 78-85. [CrossRef] [PubMed] 
87. Ling, W.C.; Lau, Y.S.; Murugan, D.D.; Vanhoutte, P.M.; Mustafa, M.R. Sodium nitrite causes relaxation of the isolated rat aorta: By stimulating both endothelial NO synthase and activating soluble guanylyl cyclase in vascular smooth muscle. Vascul. Pharmacol. 2015, 74, 87-92. [CrossRef] [PubMed]

88. Al-Nakkash, L.; Martin, J.B.; Petty, D.; Lynch, S.M.; Hamrick, C.; Lucy, D.; Robinson, J.; Peterson, A.; Rubin, L.J.; Broderick, T.L. Dietary genistein induces sex-dependent effects on murine body weight, serum profiles, and vascular function of thoracic aortae. Gend. Med. 2012, 9, 295-308. [CrossRef] [PubMed]

89. Sélley, E.; Molnár, G.A.; Kun, S.; Szijártó, I.A.; Laczy, B.; Kovács, T.; Fülöp, F.; Wittmann, I. Complex vasoactivity of liraglutide. Contribution of three gasotransmitters. Artery Res. 2015, 11, 1-9. [CrossRef]

90. Choi, S.; Jung, W.S.; Cho, N.S.; Ryu, K.H.; Jun, J.Y.; Shin, B.C.; Chung, J.H.; Yeum, C.H. Mechanisms of phytoestrogen biochanin A-induced vasorelaxation in renovascular hypertensive rats. Kidney Res. Clin. Pract. 2014, 33, 181-186. [CrossRef] [PubMed]

91. Ntchapda, F.; Talla, E.; Sakava, P.; Tanzi, F.; Fohouo, F.-N.T.; Tanyi, J.M.; Dimo, T. Nitric oxide-dependent vasodilation and Ca 2+ signalling induced by erythrodiol in rat aorta. Asian Pac. J. Trop. Dis. 2015, 5, S214-S223. [CrossRef]

92. Nsuadi Manga, F.; El Khattabi, C.; Fontaine, J.; Berkenboom, G.; Duez, P.; Noyon, C.; van Antwerpen, P.; Lami Nzunzu, J.; Pochet, S. Vasorelaxant and antihypertensive effects of methanolic extracts from Hymenocardia acida Tul. J. Ethnopharmacol. 2013, 146, 623-631. [CrossRef] [PubMed]

93. Paredes-Carbajal, M.C.; Monsalvo, I.; Hernandez-Diaz, C.; Regla, I.; Demare, P.; Mascher, D. Effects of ranolazine on vasomotor responses of rat aortic rings. Arch. Med. Res. 2013, 44, 8-12. [CrossRef] [PubMed]

94. Li, X.; Kim, H.Y.; Cui, H.Z.; Cho, K.W.; Kang, D.G.; Lee, H.S. Water extract of Zanthoxylum piperitum induces vascular relaxation via endothelium-dependent NO-cGMP signaling. J. Ethnopharmacol. 2010, 129, 197-202. [CrossRef] [PubMed]

95. Jin, S.N.; Wen, J.F.; Kim, H.Y.; Kang, D.G.; Lee, H.S.; Cho, K.W. Vascular relaxation by ethanol extract of Xanthoceras sorbifolia via Akt- and SOCE-eNOS-cGMP pathways. J. Ethnopharmacol. 2010, 132, 240-245. [CrossRef] [PubMed]

96. Kim, H.Y.; Oh, H.; Li, X.; Cho, K.W.; Kang, D.G.; Lee, H.S. Ethanol extract of seeds of Oenothera odorata induces vasorelaxation via endothelium-dependent NO-cGMP signaling through activation of Akt-eNOS-sGC pathway. J. Ethnopharmacol. 2011, 133, 315-323. [CrossRef] [PubMed]

97. Nsuadi Manga, F.; El Khattabi, C.; Fontaine, J.; Berkenboom, G.; Duez, P.; Lami Nzunzu, J.; Pochet, S. Vascular effects and antioxidant activity of two Combretum species from Democratic Republic of Congo. J. Ethnopharmacol. 2012, 142, 194-200. [CrossRef] [PubMed]

98. Bernardes, M.J.; de Carvalho, F.S.; Lima Silveira, L.; de Paula, J.R.; Bara, M.T.; Garrote, C.F.; Pedrino, G.R.; Rocha, M.L. Hypotensive effect of Aspidosperma subincanum Mart. in rats and its mechanism of vasorelaxation in isolated arteries. J. Ethnopharmacol. 2013, 145, 227-232. [CrossRef] [PubMed]

99. Senejoux, F.; Demougeot, C.; Cuciureanu, M.; Miron, A.; Cuciureanu, R.; Berthelot, A.; Girard-Thernier, C. Vasorelaxant effects and mechanisms of action of Heracleum sphondylium L. (Apiaceae) in rat thoracic aorta. J. Ethnopharmacol. 2013, 147, 536-539. [CrossRef] [PubMed]

100. Cuinas, A.; Elies, J.; Orallo, F.; Campos-Toimil, M. Cyclic AMP relaxation of rat aortic smooth muscle is mediated in part by decrease of depletion of intracellular $\mathrm{Ca}^{2+}$ stores and inhibition of capacitative calcium entry. Vascul. Pharmacol. 2013, 58, 98-104. [CrossRef] [PubMed]

101. Garcia-Morales, V.; Cuinas, A.; Elies, J.; Campos-Toimil, M. PKA and Epac activation mediates cAMP-induced vasorelaxation by increasing endothelial NO production. Vascul. Pharmacol. 2014, 60, 95-101. [CrossRef] [PubMed]

102. Deng, Y.; Ng, E.S.; Kwan, Y.W.; Lau, C.B.; Cheung, D.W.; Koon, J.C.; Zhang, Z.; Zuo, Z.; Leung, P.C.; Fung, K.P.; et al. Cerebral vasodilator properties of Danshen and Gegen: A study of their combined efficacy and mechanisms of actions. Phytomedicine 2014, 21, 391-399. [CrossRef] [PubMed]

103. Ng, H.K.; Poh, T.F.; Lam, S.K.; Hoe, S.Z. Potassium channel openers and prostacyclin play a crucial role in mediating the vasorelaxant activity of Gynura procumbens. BMC Complement. Altern. Med. 2013, 13, 188. [CrossRef] [PubMed]

104. Zhang, H.-Q.; Liu, Y.-Y.; Li, Y.-W.; Li, L.; Cui, Z.-Q. Effects of total alkaloids in Buxus microphylla leaves on aorta smooth muscle of rats and their mechanisms. Chin. Herbal Med. 2012, 4, 136-141. 
105. Potje, S.R.; Munhoz, F.C.; Perassa, L.A.; Graton, M.E.; Pereira, A.A.; Nakamune, A.C.; da Silva, R.S.; Bendhack, L.M.; Sumida, D.H.; Antoniali, C. Mechanisms underlying the hypotensive and vasodilator effects of $\mathrm{Ru}(\text { terpy)(bdq)NO}]^{3+}$, a nitric oxide donor, differ between normotensive and spontaneously hypertensive rats. Eur. J. Pharmacol. 2014, 741, 222-229. [CrossRef] [PubMed]

106. Tikoo, K.; Patel, G.; Kumar, S.; Karpe, P.A.; Sanghavi, M.; Malek, V.; Srinivasan, K. Tissue specific up regulation of ACE2 in rabbit model of atherosclerosis by atorvastatin: Role of epigenetic histone modifications. Biochem. Pharmacol. 2015, 93, 343-351. [CrossRef] [PubMed]

107. Yang, Z.; Zhang, Y.; Meng, Z. The vasodilator mechanisms of sodium metabisulfite on precontracted isolated aortic rings in rats: signal transduction pathways and ion channels. Food Chem. Toxicol. 2012, 50, 3114-3119. [CrossRef] [PubMed]

108. Senejoux, F.; Girard, C.; Kerram, P.; Aisa, H.A.; Berthelot, A.; Bevalot, F.; Demougeot, C. Mechanisms of vasorelaxation induced by Ziziphora clinopodioides Lam. (Lamiaceae) extract in rat thoracic aorta. J. Ethnopharmacol. 2010, 132, 268-273. [CrossRef] [PubMed]

109. Monteiro, F.S.; Silva, A.C.; Martins, I.R.; Correia, A.C.; Basilio, I.J.; Agra, M.F.; Bhattacharyya, J.; Silva, B.A. Vasorelaxant action of the total alkaloid fraction obtained from Solanum paludosum Moric. (Solanaceae) involves NO/cGMP/PKG pathway and potassium channels. J. Ethnopharmacol. 2012, 141, 895-900. [CrossRef] [PubMed]

110. Park, J.Y.; Choi, Y.W.; Yun, J.W.; Bae, J.U.; Seo, K.W.; Lee, S.J.; Park, S.Y.; Kim, C.D. Gomisin J from Schisandra chinensis induces vascular relaxation via activation of endothelial nitric oxide synthase. Vascul. Pharmacol. 2012, 57, 124-130. [CrossRef] [PubMed]

111. Garcia-Prieto, C.F.; Pulido-Olmo, H.; Ruiz-Hurtado, G.; Gil-Ortega, M.; Aranguez, I.; Rubio, M.A.; Ruiz-Gayo, M.; Somoza, B.; Fernandez-Alfonso, M.S. Mild caloric restriction reduces blood pressure and activates endothelial AMPK-PI3K-Akt-eNOS pathway in obese Zucker rats. Vascul. Pharmacol. 2015, 65-66, 3-12. [CrossRef] [PubMed]

112. Choudhury, S.; Kannan, K.; Pule Addison, M.; Darzi, S.A.; Singh, V.; Singh, T.U.; Thangamalai, R.; Dash, J.R.; Parida, S.; Debroy, B.; et al. Combined treatment with atorvastatin and imipenem improves survival and vascular functions in mouse model of sepsis. Vascul. Pharmacol. 2015, 71, 139-150. [CrossRef] [PubMed]

113. Masszi, G.; Novak, A.; Tarszabo, R.; Horvath, E.M.; Buday, A.; Ruisanchez, E.; Tokes, A.M.; Sara, L.; Benko, R.; Nadasy, G.L.; et al. Effects of vitamin $\mathrm{D}_{3}$ derivative-Calcitriol on pharmacological reactivity of aortic rings in a rodent PCOS model. Pharmacol. Rep. 2013, 65, 476-483. [CrossRef]

114. Kazmierczak, P.A.; Dobaczewski, M.P.; Przygodzki, T.; Carsky, J.; Watala, C. $\beta$-Resorcylidene aminoguanidine (RAG) dilates coronary arteries in an endothelium-independent manner. Pharmacol. Rep. 2015, 67, 631-635. [CrossRef] [PubMed]

115. Munin, J.; Quezada, E.; Cuinas, A.; Campos-Toimil, M.; Uriarte, E.; Santana, L.; Vina, D. Synthesis, biological evaluation and structure-activity relationships of new phthalazinedione derivatives with vasorelaxant activity. Eur. J. Med. Chem. 2014, 82, 407-417. [CrossRef] [PubMed]

116. Meyer, M.R.; Barton, M.; Prossnitz, E.R. Functional heterogeneity of NADPH oxidase-mediated contractions to endothelin with vascular aging. Life Sci. 2014, 118, 226-231. [CrossRef] [PubMed]

117. Maia-Joca, R.P.; Joca, H.C.; Ribeiro, F.J.; do Nascimento, R.V.; Silva-Alves, K.S.; Cruz, J.S.; Coelho-de-Souza, A.N.; Leal-Cardoso, J.H. Investigation of terpinen-4-ol effects on vascular smooth muscle relaxation. Life Sci. 2014, 115, 52-58. [CrossRef] [PubMed]

118. Kamiya, T.; Nagaoka, T.; Omae, T.; Yoshioka, T.; Ono, S.; Tanano, I.; Yoshida, A. Role of $\mathrm{Ca}^{2+}$-dependent and $\mathrm{Ca}^{2+}$-sensitive mechanisms in sphingosine 1-phosphate-induced constriction of isolated porcine retinal arterioles in vitro. Exp. Eye Res. 2014, 121, 94-101. [CrossRef] [PubMed]

119. Fajemiroye, J.O.; Amaral, N.O.; da Silva, E.F.; Galdino, P.M.; de Oliveira, T.S.; Ghedini, P.C.; Zjawiony, J.K.; Costa, E.A.; Pedrino, G.R.; Menegatti, R. Hypotensive and antihypertensive potential of 4-[(1-phenyl-1H-pyrazol-4-yl) methyl]1-piperazine carboxylic acid ethyl ester: A piperazine derivative. Life Sci. 2014, 112, 90-96. [CrossRef] [PubMed]

120. Tom, E.N.; Girard-Thernier, C.; Martin, H.; Dimo, T.; Alvergnas, M.; Nappey, M.; Berthelot, A.; Demougeot, C. Treatment with an extract of Terminalia superba Engler \& Diels decreases blood pressure and improves endothelial function in spontaneously hypertensive rats. J. Ethnopharmacol. 2014, 151, 372-379. [PubMed] 
121. Boonla, O.; Kukongviriyapan, U.; Pakdeechote, P.; Kukongviriyapan, V.; Pannangpetch, P.; Prachaney, P.; Greenwald, S.E. Curcumin improves endothelial dysfunction and vascular remodeling in $2 \mathrm{~K}-1 \mathrm{C}$ hypertensive rats by raising nitric oxide availability and reducing oxidative stress. Nitric Oxide 2014, 42, 44-53. [CrossRef] [PubMed]

122. Inoue, Y.; Nakahara, K.; Maruyama, K.; Suzuki, Y.; Hayashi, Y.; Kangawa, K.; Murakami, N. Central and peripheral des-acyl ghrelin regulates body temperature in rats. Biochem. Biophys. Res. Commun. 2013, 430, 278-283. [CrossRef] [PubMed]

123. Pereira, S.L.; Kummerle, A.E.; Fraga, C.A.; Barreiro, E.J.; Rocha Nde, N.; Ferraz, E.B.; do Nascimento, J.H.; Sudo, R.T.; Zapata-Sudo, G. A novel $\mathrm{Ca}^{2+}$ channel antagonist reverses cardiac hypertrophy and pulmonary arteriolar remodeling in experimental pulmonary hypertension. Eur. J. Pharmacol. 2013, 702, 316-322. [CrossRef] [PubMed]

124. Priestley, J.R.; Buelow, M.W.; McEwen, S.T.; Weinberg, B.D.; Delaney, M.; Balus, S.F.; Hoeppner, C.; Dondlinger, L.; Lombard, J.H. Reduced angiotensin II levels cause generalized vascular dysfunction via oxidant stress in hamster cheek pouch arterioles. Microvasc. Res. 2013, 89, 134-145. [CrossRef] [PubMed]

125. Babacanoglu, C.; Yildirim, N.; Sadi, G.; Pektas, M.B.; Akar, F. Resveratrol prevents high-fructose corn syrup-induced vascular insulin resistance and dysfunction in rats. Food Chem. Toxicol. 2013, 60, 160-167. [CrossRef] [PubMed]

126. Sinagra, T.; Tamburella, A.; Urso, V.; Siarkos, I.; Drago, F.; Bucolo, C.; Salomone, S. Reversible inhibition of vasoconstriction by thiazolidinediones related to PI3K/Akt inhibition in vascular smooth muscle cells. Biochem. Pharmacol. 2013, 85, 551-559. [CrossRef] [PubMed]

127. Brito, T.S.; Lima, F.J.; Aragao, K.S.; de Siqueira, R.J.; Sousa, P.J.; Maia, J.G.; Filho, J.D.; Lahlou, S.; Magalhaes, P.J. The vasorelaxant effects of 1-nitro-2-phenylethane involve stimulation of the soluble guanylate cyclase-cGMP pathway. Biochem. Pharmacol. 2013, 85, 780-788. [CrossRef] [PubMed]

128. Simões, M.R.; Furieri, L.B.; Forechi, L.; Baldo, M.P.; Rodrigues, S.L.; Salaices, M.; Vassallo, D.V.; Mill, J.G. High salt intake does not produce additional impairment in the coronary artery relaxation of spontaneously hypertensive aged rats. Food Chem. Toxicol. 2013, 58, 193-197. [CrossRef] [PubMed]

129. Roberts, R.E.; Allen, S.; Chang, A.P.; Henderson, H.; Hobson, G.C.; Karania, B.; Morgan, K.N.; Pek, A.S.; Raghvani, K.; Shee, C.Y.; et al. Distinct mechanisms of relaxation to bioactive components from chamomile species in porcine isolated blood vessels. Toxicol. Appl. Pharmacol. 2013, 272, 797-805. [CrossRef] [PubMed]

130. Centeno, J.M.; Marrachelli, V.G.; Miranda, L.; Castello-Ruiz, M.; Burguete, M.C.; Jover-Mengual, T.; Salom, J.B.; Torregrosa, G.; Miranda, F.J.; Alborch, E. Involvement of prostacyclin and potassium channels in the diabetes-induced hyporeactivity of the rabbit carotid artery to B-type natriuretic peptide. Eur. J. Pharmacol. 2013, 701, 159-167. [CrossRef] [PubMed]

131. Oh, K.S.; Oh, B.K.; Park, C.H.; Seo, H.W.; Kang, N.S.; Lee, J.H.; Lee, J.S.; Ho Lee, B. Cardiovascular effects of a novel selective Rho kinase inhibitor, 2-(1H-indazole-5-yl)amino-4-methoxy-6-piperazino triazine (DW1865). Eur. J. Pharmacol. 2013, 702, 218-226. [CrossRef] [PubMed]

132. Kriska, T.; Cepura, C.; Siangjong, L.; Wan, T.C.; Auchampach, J.A.; Shaish, A.; Haratz, D.; Kumar, G.; Falck, J.R.; Gauthier, K.M.; et al. Effect of human 15-lipoxygenase-1 metabolites on vascular function in mouse mesenteric arteries and hearts. Prostaglandins Other Lipid Mediat. 2013, 106, 8-15. [CrossRef] [PubMed]

133. Nofal, Z.M.; Srour, A.M.; El-Eraky, W.I.; Saleh, D.O.; Girgis, A.S. Rational design, synthesis and QSAR study of vasorelaxant active 3-pyridinecarbonitriles incorporating 1H-benzimidazol-2-yl function. Eur. J. Med. Chem. 2013, 63, 14-21. [CrossRef] [PubMed]

134. Wang, T.T.; Zhou, G.H.; Kho, J.H.; Sun, Y.Y.; Wen, J.F.; Kang, D.G.; Lee, H.S.; Cho, K.W.; Jin, S.N. Vasorelaxant action of an ethylacetate fraction of Euphorbia humifusa involves NO-cGMP pathway and potassium channels. J. Ethnopharmacol. 2013, 148, 655-663. [CrossRef] [PubMed]

135. Gortan Cappellari, G.; Losurdo, P.; Mazzucco, S.; Panizon, E.; Jevnicar, M.; Macaluso, L.; Fabris, B.; Barazzoni, R.; Biolo, G.; Carretta, R.; et al. Treatment with $n-3$ polyunsaturated fatty acids reverses endothelial dysfunction and oxidative stress in experimental menopause. J. Nutr. Biochem. 2013, 24, 371-379. [CrossRef] [PubMed]

136. Martelli, A.; Testai, L.; Breschi, M.C.; Lawson, K.; McKay, N.G.; Miceli, F.; Taglialatela, M.; Calderone, V. Vasorelaxation by hydrogen sulphide involves activation of Kv7 potassium channels. Pharmacol. Res. 2013, 70, 27-34. [CrossRef] [PubMed] 
137. Sukumaran, S.V.; Singh, T.U.; Parida, S.; Narasimha Reddy Ch, E.; Thangamalai, R.; Kandasamy, K.; Singh, V.; Mishra, S.K. TRPV4 channel activation leads to endothelium-dependent relaxation mediated by nitric oxide and endothelium-derived hyperpolarizing factor in rat pulmonary artery. Pharmacol. Res. 2013, 78, 18-27. [CrossRef] [PubMed]

138. Yan, J.; Chen, R.; Liu, P.; Gu, Y. Docosahexaenoic acid attenuates hypoxic pulmonary vasoconstriction by activating the large conductance $\mathrm{Ca}^{2+}$-activated $\mathrm{K}^{+}$currents in pulmonary artery smooth muscle cells. Pulm. Pharmacol. Ther. 2014, 28, 9-16. [CrossRef] [PubMed]

139. Cekic, E.G.; Soydan, G.; Guler, S.; Babaoglu, M.O.; Tuncer, M. Propranolol-induced relaxation in the rat basilar artery. Vascul. Pharmacol. 2013, 58, 307-312. [CrossRef] [PubMed]

140. Dalaklioglu, S.; Tasatargil, A.; Kale, S.; Tanriover, G.; Dilmac, S.; Erin, N. Metastatic breast carcinoma induces vascular endothelial dysfunction in Balb-c mice: Role of the tumor necrosis factor- $\alpha$ and NADPH oxidase. Vascul. Pharmacol. 2013, 59, 103-111. [CrossRef] [PubMed]

141. El-Kashef, D.H.; El-Agamy, D.S.; Gamil, N.M. Protective effects of hydrogen sulfide against high glucose induced-endothelial dysfunction: An in vitro study. J. Taibah Univ. Sci. 2013, 7, 97-104. [CrossRef]

142. Senbel, A.M.; Omar, A.G.; Abdel-Moneim, L.M.; Mohamed, H.F.; Daabees, T.T. Evaluation of L-arginine on kidney function and vascular reactivity following ischemic injury in rats: protective effects and potential interactions. Pharmacol. Rep. 2014, 66, 976-983. [CrossRef] [PubMed]

143. Li, L.; Yang, H.G.; Yuan, T.Y.; Zhao, Y.; Du, G.H. Rho kinase inhibition activity of pinocembrin in rat aortic rings contracted by angiotensin II. Chin. J. Nat. Med. 2013, 11, 258-263. [CrossRef] [PubMed]

144. McCormick, C.; Jones, R.L.; Kennedy, S.; Wadsworth, R.M. Activation of prostanoid EP receptors by prostacyclin analogues in rabbit iliac artery: implications for anti-restenotic potential. Eur. J. Pharmacol. 2010, 641, 160-167. [CrossRef] [PubMed]

145. Takebayashi, K.; Sohma, R.; Aso, Y.; Inukai, T. Effects of retinol binding protein-4 on vascular endothelial cells. Biochem. Biophys. Res. Commun. 2011, 408, 58-64. [CrossRef] [PubMed]

146. Matsuo, Y.; Kuwabara, M.; Tanaka-Totoribe, N.; Kanai, T.; Nakamura, E.; Gamoh, S.; Suzuki, A.; Asada, Y.; Hisa, H.; Yamamoto, R. The defective protein level of myosin light chain phosphatase (MLCP) in the isolated saphenous vein, as a vascular conduit in coronary artery bypass grafting (CABG), harvested from patients with diabetes mellitus (DM). Biochem. Biophys. Res. Commun. 2011, 412, 323-327. [CrossRef] [PubMed]

147. Giustarini, D.; Tsikas, D.; Rossi, R. Study of the effect of thiols on the vasodilatory potency of $S$-nitrosothiols by using a modified aortic ring assay. Toxicol. Appl. Pharmacol. 2011, 256, 95-102. [CrossRef] [PubMed]

148. Lu, C.; Su, L.Y.; Lee, R.M.; Gao, Y.J. Alterations in perivascular adipose tissue structure and function in hypertension. Eur. J. Pharmacol. 2011, 656, 68-73. [CrossRef] [PubMed]

149. Sapa, J.; Kubacka, M. The possible mechanism of hypotensive activity of some pyrrolidin-2-one derivatives with antagonist properties at $\alpha_{1}$-adrenoceptors. Eur. J. Pharmacol. 2011, 673, 40-48. [CrossRef] [PubMed]

150. Lamarre, N.S.; Parry, T.; Tallarida, R.J. On the quantitation of an agonist with dual but opposing components of action: Application to vascular endothelial relaxation. Eur. J. Pharmacol. 2011, 670, 204-207. [CrossRef] [PubMed]

151. Van Drongelen, J.; Pertijs, J.; Wouterse, A.; Hermsen, R.; Sweep, F.C.; Lotgering, F.K.; Smits, P.; Spaanderman, M.E. Contribution of different local vascular responses to mid-gestational vasodilation. Am. J. Obstet. Gynecol. 2011, 205, 155.e12-155.e17. [CrossRef] [PubMed]

152. Yamazaki, T.; Anraku, T.; Matsuzawa, S. Ibudilast, a mixed PDE3/4 inhibitor, causes a selective and nitric oxide/cGMP-independent relaxation of the intracranial vertebrobasilar artery. Eur. J. Pharmacol. 2011, 650, 605-611. [CrossRef] [PubMed]

153. Fiorim, J.; Ribeiro, R.F., Jr.; Azevedo, B.F.; Simoes, M.R.; Padilha, A.S.; Stefanon, I.; Alonso, M.J.; Salaices, M.; Vassallo, D.V. Activation of $\mathrm{K}+$ channels and $\mathrm{Na}^{+} / \mathrm{K}^{+}$ATPase prevents aortic endothelial dysfunction in 7-day lead-treated rats. Toxicol. Appl. Pharmacol. 2012, 262, 22-31. [CrossRef] [PubMed]

154. Agbor, L.N.; Walsh, M.T.; Boberg, J.R.; Walker, M.K. Elevated blood pressure in cytochrome P4501A1 knockout mice is associated with reduced vasodilation to omega-3 polyunsaturated fatty acids. Toxicol. Appl. Pharmacol. 2012, 264, 351-360. [CrossRef] [PubMed]

155. Zapata-Sudo, G.; Pontes, L.B.; da Silva, J.S.; Lima, L.M.; Nunes, I.K.; Barreiro, E.J.; Sudo, R.T. Benzenesulfonamide attenuates monocrotaline-induced pulmonary arterial hypertension in a rat model. Eur. J. Pharmacol. 2012, 690, 176-182. [CrossRef] [PubMed] 
156. Sara, L.; Antal, P.; Masszi, G.; Buday, A.; Horvath, E.M.; Hamar, P.; Monos, E.; Nadasy, G.L.; Varbiro, S. Arteriolar insulin resistance in a rat model of polycystic ovary syndrome. Fertil. Steril. 2012, 97, 462-468. [CrossRef] [PubMed]

157. Alvarez-Medina, D.I.; Hernandez, A.; Orozco, C. Endothelial hyperpolarizing factor increases acetylcholine-induced vasodilatation in pulmonary hypertensive broilers arterial rings. Res. Vet. Sci. 2012, 92, 1-6. [CrossRef] [PubMed]

158. Liao, S.B.; O, W.S.; Tang, F. Adrenomedullin inhibits norepinephrine-induced contraction of rat seminal vesicle. Urology 2012, 80, 224.e1-224.e5. [CrossRef] [PubMed]

159. Meng, Z.; Yang, Z.; Li, J.; Zhang, Q. The vasorelaxant effect and its mechanisms of sodium bisulfite as a sulfur dioxide donor. Chemosphere 2012, 89, 579-584. [CrossRef] [PubMed]

160. Xie, W.; Zhang, X.; Wang, T.; Hu, J. Botany, traditional uses, phytochemistry and pharmacology of Apocynum venetum L. (Luobuma): A review. J. Ethnopharmacol. 2012, 141, 1-8. [CrossRef] [PubMed]

161. Quintela, A.M.; Jimenez, R.; Gomez-Guzman, M.; Zarzuelo, M.J.; Galindo, P.; Sanchez, M.; Vargas, F.; Cogolludo, A.; Tamargo, J.; Perez-Vizcaino, F.; et al. Activation of peroxisome proliferator-activated receptor- $\beta /-\delta(\operatorname{PAAR} \beta / \delta)$ prevents endothelial dysfunction in type 1 diabetic rats. Free Radic. Biol. Med. 2012, 53, 730-741. [CrossRef] [PubMed]

162. Del Bo, C.; Kristo, A.S.; Kalea, A.Z.; Ciappellano, S.; Riso, P.; Porrini, M.; Klimis-Zacas, D. The temporal effect of a wild blueberry (Vaccinium angustifolium)-enriched diet on vasomotor tone in the Sprague-Dawley rat. Nutr. Metab. Cardiovasc. Dis. 2012, 22, 127-132. [CrossRef] [PubMed]

163. Jerez, S.; Sierra, L.; de Bruno, M.P. 17-Octadecynoic acid improves contractile response to angiotensin II by releasing vasocontrictor prostaglandins. Prostaglandins Other Lipid Mediat. 2012, 97, 36-42. [CrossRef] [PubMed]

164. Matsumoto, T.; Szasz, T.; Tostes, R.C.; Webb, R.C. Impaired $\beta$-adrenoceptor-induced relaxation in small mesenteric arteries from DOCA-salt hypertensive rats is due to reduced $\mathrm{K}(\mathrm{Ca})$ channel activity. Pharmacol. Res. 2012, 65, 537-545. [CrossRef] [PubMed]

165. Pan, C.; Huo, Y.; An, X.; Singh, G.; Chen, M.; Yang, Z.; Pu, J.; Li, J. Panax notoginseng and its components decreased hypertension via stimulation of endothelial-dependent vessel dilatation. Vascul. Pharmacol. 2012, 56, 150-158. [CrossRef] [PubMed]

166. Aloysius, U.I.; Achike, F.I.; Mustafa, M.R. Mechanisms underlining gender differences in Phenylephrine contraction of normoglycaemic and short-term Streptozotocin-induced diabetic WKY rat aorta. Vascul. Pharmacol. 2012, 57, 81-90. [CrossRef] [PubMed]

167. Pelham, C.J.; Ketsawatsomkron, P.; Groh, S.; Grobe, J.L.; de Lange, W.J.; Ibeawuchi, S.R.; Keen, H.L.; Weatherford, E.T.; Faraci, F.M.; Sigmund, C.D. Cullin-3 regulates vascular smooth muscle function and arterial blood pressure via PPARgamma and RhoA/Rho-kinase. Cell Metab. 2012, 16, 462-472. [CrossRef] [PubMed]

168. Beleznai, T.; Bagi, Z. Activation of hexosamine pathway impairs nitric oxide (NO)-dependent arteriolar dilations by increased protein O-GlcNAcylation. Vascul. Pharmacol. 2012, 56, 115-121. [CrossRef] [PubMed]

169. Chen, B.; Shi, L.; Yu, X.; Sun, J.; Zhang, H.; Wang, S.; Fang, L.; Du, G. Differential effects of Rho-kinase inhibitor and angiotensin II type-1 receptor antagonist on the vascular function in hypertensive rats induced by chronic L-NAME treatment. Acta Pharm. Sin. B 2012, 2, 450-458. [CrossRef]

170. Haines, R.J.; Corbin, K.D.; Pendleton, L.C.; Meininger, C.J.; Eichler, D.C. Insulin transcriptionally regulates argininosuccinate synthase to maintain vascular endothelial function. Biochem. Biophys. Res. Commun. 2012, 421, 9-14. [CrossRef] [PubMed]

171. Davel, A.P.; Lemos, M.; Pastro, L.M.; Pedro, S.C.; de Andre, P.A.; Hebeda, C.; Farsky, S.H.; Saldiva, P.H.; Rossoni, L.V. Endothelial dysfunction in the pulmonary artery induced by concentrated fine particulate matter exposure is associated with local but not systemic inflammation. Toxicology 2012, 295, 39-46. [CrossRef] [PubMed]

172. Toba, H.; Tojo, C.; Wang, J.; Noda, K.; Kobara, M.; Nakata, T. Telmisartan inhibits vascular dysfunction and inflammation via activation of peroxisome proliferator-activated receptor-gamma in subtotal nephrectomized rat. Eur. J. Pharmacol. 2012, 685, 91-98. [CrossRef] [PubMed]

173. Murakami, K.; Inoue, N.; Fuchikami, C.; Tajima, K.; Hashino, A.; Fukui, H.; Noda, K.; Oka, M. Blockade of voltage-gated calcium channel $\mathrm{Ca}_{\mathrm{v}} 1.2$ and $\alpha_{1}$-adrenoceptors increases vertebral artery blood flow induced by the antivertigo agent difenidol. Eur. J. Pharmacol. 2012, 689, 165-171. [CrossRef] [PubMed] 
174. Sathishkumar, K.; Elkins, R.; Yallampalli, U.; Balakrishnan, M.; Yallampalli, C. Fetal programming of adult hypertension in female rat offspring exposed to androgens in utero. Early Hum. Dev. 2011, 87, 407-414. [CrossRef] [PubMed]

175. Malakul, W.; Thirawarapan, S.; Ingkaninan, K.; Sawasdee, P. Effects of Kaempferia parviflora Wall. Ex Baker on endothelial dysfunction in streptozotocin-induced diabetic rats. J. Ethnopharmacol. 2011, 133, 371-377. [CrossRef] [PubMed]

176. Malakul, W.; Ingkaninan, K.; Sawasdee, P.; Woodman, O.L. The ethanolic extract of Kaempferia parviflora reduces ischaemic injury in rat isolated hearts. J. Ethnopharmacol. 2011, 137, 184-191. [CrossRef] [PubMed]

177. Bertin, R.; Garcia-Argaez, A.; Martinez-Vazquez, M.; Froldi, G. Age-dependent vasorelaxation of Casimiroa edulis and Casimiroa pubescens extracts in rat caudal artery in vitro. J. Ethnopharmacol. 2011, 137, 934-936. [CrossRef] [PubMed]

178. Witting, P.K.; Song, C.; Hsu, K.; Hua, S.; Parry, S.N.; Aran, R.; Geczy, C.; Freedman, S.B. The acute-phase protein serum amyloid A induces endothelial dysfunction that is inhibited by high-density lipoprotein. Free Radic. Biol. Med. 2011, 51, 1390-1398. [CrossRef] [PubMed]

179. Matsuo, H.; Okamoto, R.; Zaima, K.; Hirasawa, Y.; Ismail, I.S.; Lajis, N.H.; Morita, H. New vasorelaxant indole alkaloids, villocarines A-D from Uncaria villosa. Bioorg. Med. Chem. 2011, 19, 4075-4079. [CrossRef] [PubMed]

180. Morita, H.; Zaima, K.; Koga, I.; Saito, A.; Tamamoto, H.; Okazaki, H.; Kaneda, T.; Hashimoto, T.; Asakawa, Y. Vasorelaxant effects of macrocyclic bis(bibenzyls) from liverworts. Bioorg. Med. Chem. 2011, 19, 4051-4056. [CrossRef] [PubMed]

181. Monroy-Ruiz, J.; Sevilla, M.A.; Carron, R.; Montero, M.J. Astaxanthin-enriched-diet reduces blood pressure and improves cardiovascular parameters in spontaneously hypertensive rats. Pharmacol. Res. 2011, 63, 44-50. [CrossRef] [PubMed]

182. Siarkos, I.; Urso, V.; Sinagra, T.; Drago, F.; Salomone, S. Endothelium-dependent vasomotor effects of telmisartan in isolated rat femoral arteries. Pharmacol. Res. 2011, 63, 199-206. [CrossRef] [PubMed]

183. Wojcicka, G.; Jamroz-Wisniewska, A.; Atanasova, P.; Chaldakov, G.N.; Chylinska-Kula, B.; Beltowski, J. Differential effects of statins on endogenous $\mathrm{H} 2 \mathrm{~S}$ formation in perivascular adipose tissue. Pharmacol. Res. 2011, 63, 68-76. [CrossRef] [PubMed]

184. Marrachelli, V.G.; Miranda, F.J.; Centeno, J.M.; Miranda, I.; Castello-Ruiz, M.; Burguete, M.C.; Jover-Mengual, T.; Salom, J.B.; Torregrosa, G.; Alborch, E. Mechanisms underlying the diabetes-induced hyporeactivity of the rabbit carotid artery to atrial natriuretic peptide. Pharmacol. Res. 2011, 63, 190-198. [CrossRef] [PubMed]

185. Sciorati, C.; Miglietta, D.; Buono, R.; Pisa, V.; Cattaneo, D.; Azzoni, E.; Brunelli, S.; Clementi, E. A dual acting compound releasing nitric oxide (NO) and ibuprofen, NCX 320, shows significant therapeutic effects in a mouse model of muscular dystrophy. Pharmacol. Res. 2011, 64, 210-217. [CrossRef] [PubMed]

186. Cantu-Medellin, N.; Vitturi, D.A.; Rodriguez, C.; Murphy, S.; Dorman, S.; Shiva, S.; Zhou, Y.; Jia, Y.; Palmer, A.F.; Patel, R.P. Effects of T- and R-state stabilization on deoxyhemoglobin-nitrite reactions and stimulation of nitric oxide signaling. Nitric Oxide 2011, 25, 59-69. [CrossRef] [PubMed]

187. Pereira, A.D.C.; Ford, P.C.; da Silva, R.S.; Bendhack, L.M. Ruthenium-nitrite complex as pro-drug releases NO in a tissue and enzyme-dependent way. Nitric Oxide 2011, 24, 192-198. [CrossRef] [PubMed]

188. Mei, Y.; Jin, H.; Tian, W.; Wang, H.; Wang, H.; Zhao, Y.; Zhang, Z.; Meng, F. Urantide alleviates monocrotaline induced pulmonary arterial hypertension in Wistar rats. Pulm. Pharmacol. Ther. 2011, 24, 386-393. [CrossRef] [PubMed]

189. Li, Q.; Chen, Y.; Sun, L.; Fu, G.; Guo, L. Vasodilatation produced by fasudil mesylate in vivo and in vitro. Vascul. Pharmacol. 2011, 55, 121-126. [CrossRef] [PubMed]

190. Jayakumar, T.; Sheu, J.-R. Cardiovascular pharmacological actions of rutaecarpine, a quinazolinocarboline alkaloid isolated from Evodia rutaecarpa. J. Exp. Clin. Med. 2011, 3, 63-69. [CrossRef]

191. Choi, H.; Tostes, R.C.; Webb, R.C. Mitochondrial aldehyde dehydrogenase prevents ROS-induced vascular contraction in angiotensin-II hypertensive mice. J. Am. Soc. Hypertens. 2011, 5, 154-160. [CrossRef] [PubMed]

192. Medei, E.; Lima-Leopoldo, A.P.; Pereira-Junior, P.P.; Leopoldo, A.S.; Campos, D.H.S.; Raimundo, J.M.; Sudo, R.T.; Zapata-Sudo, G.; Bruder-Nascimento, T.; Cordellini, S. Could a high-fat diet rich in unsaturated fatty acids impair the cardiovascular system? Can. J. Cardiol. 2010, 26, 542-548. [CrossRef] 
193. Wang, J.; Dong, M.Q.; Liu, M.L.; Xu, D.Q.; Luo, Y.; Zhang, B.; Liu, L.L.; Xu, M.; Zhao, P.T.; Gao, Y.Q.; et al. Tanshinone IIA modulates pulmonary vascular response to agonist and hypoxia primarily via inhibiting $\mathrm{Ca}^{2+}$ influx and release in normal and hypoxic pulmonary hypertension rats. Eur. J. Pharmacol. 2010, 640, 129-138. [CrossRef] [PubMed]

194. Shen, D.; Xu, X.; Zhang, L.; Wu, H.; Peng, L. Identification of a nitric oxide-dependent hypotensive effect of anticoagulation factor II from the venom of Agkistrodon acutus. Biochem. Pharmacol. 2010, 79, 498-506. [CrossRef] [PubMed]

195. Chen, G.P.; Li, L.; Yang, Y.; Fu, M.; Yao, L.; Wu, T.; Zhang, X.Q.; Hu, S.J. Chronic inhibition of farnesyl pyrophosphate synthase improves endothelial function in spontaneously hypertensive rats. Biochem. Pharmacol. 2010, 80, 1684-1689. [CrossRef] [PubMed]

196. Romero, M.; Jimenez, R.; Hurtado, B.; Moreno, J.M.; Rodriguez-Gomez, I.; Lopez-Sepulveda, R.; Zarzuelo, A.; Perez-Vizcaino, F.; Tamargo, J.; Vargas, F.; et al. Lack of beneficial metabolic effects of quercetin in adult spontaneously hypertensive rats. Eur. J. Pharmacol. 2010, 627, 242-250. [CrossRef] [PubMed]

197. Subramani, J.; Leo, M.D.; Kathirvel, K.; Arunadevi, R.; Singh, T.U.; Prakash, V.R.; Mishra, S.K. Essential role of nitric oxide in sepsis-induced impairment of endothelium-derived hyperpolarizing factor-mediated relaxation in rat pulmonary artery. Eur. J. Pharmacol. 2010, 630, 84-91. [CrossRef] [PubMed]

198. Zhang, H.T.; Wang, Y.; Deng, X.L.; Dong, M.Q.; Zhao, L.M.; Wang, Y.W. Daidzein relaxes rat cerebral basilar artery via activation of large-conductance $\mathrm{Ca}^{2+}$-activated $\mathrm{K}^{+}$channels in vascular smooth muscle cells. Eur. J. Pharmacol. 2010, 630, 100-106. [CrossRef] [PubMed]

199. Singh, T.U.; Kathirvel, K.; Choudhury, S.; Garg, S.K.; Mishra, S.K. Eicosapentaenoic acid-induced endothelium-dependent and -independent relaxation of sheep pulmonary artery. Eur. J. Pharmacol. 2010, 636, 108-113. [CrossRef] [PubMed]

200. Enkhjargal, B.; Hashimoto, M.; Sakai, Y.; Shido, O. Characterization of vasoconstrictor-induced relaxation in the cerebral basilar artery. Eur. J. Pharmacol. 2010, 637, 118-123. [CrossRef] [PubMed]

201. Sanchez, A.; Recio, P.; Orensanz, L.M.; Bustamante, S.; Navarro-Dorado, J.; Climent, B.; Benedito, S.; Garcia-Sacristan, A.; Prieto, D.; Hernandez, M. Mechanisms involved in the effects of endothelin-1 in pig prostatic small arteries. Eur. J. Pharmacol. 2010, 640, 190-196. [CrossRef] [PubMed]

202. Bayram, Z.; Golbasi, I.; Ozdem, S.S. The role of nitric oxide and potassium channels in the effect of adrenomedullin in human internal thoracic arteries. Regul. Pept. 2010, 161, 92-96. [CrossRef] [PubMed]

203. Franca-Silva, M.S.; Luciano, M.N.; Ribeiro, T.P.; Silva, J.S.; Santos, A.F.; Franca, K.C.; Nakao, L.S.; Athayde-Filho, P.F.; Braga, V.A.; Medeiros, I.A. The 2-nitrate-1,3-dibuthoxypropan, a new nitric oxide donor, induces vasorelaxation in mesenteric arteries of the rat. Eur. J. Pharmacol. 2012, 690, 170-175. [CrossRef] [PubMed]

204. Perusquia, M.; Espinoza, J.; Montano, L.M.; Stallone, J.N. Regional differences in the vasorelaxing effects of testosterone and its 5-reduced metabolites in the canine vasculature. Vascul. Pharmacol. 2012, 56, 176-182. [CrossRef] [PubMed]

205. Arai, H.; Zaima, K.; Mitsuta, E.; Tamamoto, H.; Saito, A.; Hirasawa, Y.; Rahman, A.; Kusumawati, I.; Zaini, N.C.; Morita, H. Alstiphyllanines I-O, ajmaline type alkaloids from Alstonia macrophylla showing vasorelaxant activity. Bioorg. Med. Chem. 2012, 20, 3454-3459. [CrossRef] [PubMed]

206. Marrachelli, V.G.; Centeno, J.M.; Miranda, I.; Castello-Ruiz, M.; Burguete, M.C.; Jover-Mengual, T.; Salom, J.B.; Torregrosa, G.; Miranda, F.J.; Alborch, E. Diabetes impairs the atrial natriuretic peptide relaxant action mediated by potassium channels and prostacyclin in the rabbit renal artery. Pharmacol. Res. 2012, 66, 392-400. [CrossRef] [PubMed]

207. Lu, Y.; Fu, Y.; Ge, Y.; Juncos, L.A.; Reckelhoff, J.F.; Liu, R. The vasodilatory effect of testosterone on renal afferent arterioles. Gend. Med. 2012, 9, 103-111. [CrossRef] [PubMed]

208. Sodhi, K.; Puri, N.; Inoue, K.; Falck, J.R.; Schwartzman, M.L.; Abraham, N.G. EET agonist prevents adiposity and vascular dysfunction in rats fed a high fat diet via a decrease in Bach 1 and an increase in HO-1 levels. Prostaglandins Other Lipid Mediat. 2012, 98, 133-142. [CrossRef] [PubMed]

209. Lesniewski, L.A.; Zigler, M.C.; Durrant, J.R.; Donato, A.J.; Seals, D.R. Sustained activation of AMPK ameliorates age-associated vascular endothelial dysfunction via a nitric oxide-independent mechanism. Mech. Ageing Dev. 2012, 133, 368-371. [CrossRef] [PubMed] 
210. Shuto, H.; Tominaga, K.; Yamauchi, A.; Ikeda, M.; Kusaba, K.; Mitsunaga, D.; Hirabara, Y.; Egawa, T.; Takano, Y.; Kataoka, Y. The statins fluvastatin and pravastatin exert anti-flushing effects by improving vasomotor dysfunction through nitric oxide-mediated mechanisms in ovariectomized animals. Eur. J. Pharmacol. 2011, 651, 234-239. [CrossRef] [PubMed]

211. Toba, H.; Morishita, M.; Tojo, C.; Nakano, A.; Oshima, Y.; Kojima, Y.; Yoshida, M.; Nakashima, K.; Wang, J.; Kobara, M.; et al. Recombinant human erythropoietin ameliorated endothelial dysfunction and macrophage infiltration by increasing nitric oxide in hypertensive 5/6 nephrectomized rat aorta. Eur. J. Pharmacol. 2011, 656, 81-87. [CrossRef] [PubMed]

212. Garcia-Villalon, A.L.; Fernandez, N.; Monge, L.; Dieguez, G. Coronary response to diadenosine tetraphosphate after ischemia-reperfusion in the isolated rat heart. Eur. J. Pharmacol. 2011, 660, $394-401$. [CrossRef] [PubMed]

213. Medeiros, M.A.; Pinho, J.F.; De-Lira, D.P.; Barbosa-Filho, J.M.; Araujo, D.A.; Cortes, S.F.; Lemos, V.S.; Cruz, J.S. Curine, a bisbenzylisoquinoline alkaloid, blocks L-type $\mathrm{Ca}^{2+}$ channels and decreases intracellular $\mathrm{Ca}^{2+}$ transients in A7r5 cells. Eur. J. Pharmacol. 2011, 669, 100-107. [CrossRef] [PubMed]

214. Wang, X.B.; Jin, H.F.; Tang, C.S.; Du, J.B. The biological effect of endogenous sulfur dioxide in the cardiovascular system. Eur. J. Pharmacol. 2011, 670,1-6. [CrossRef] [PubMed]

215. de Buys Roessingh, A.; Fouquet, V.; Aigrain, Y.; Mercier, J.-C.; de Lagausie, P.; Dinh-Xuan, A.T. Nitric oxide activity through guanylate cyclase and phosphodiesterase modulation is impaired in fetal lambs with congenital diaphragmatic hernia. J. Pediatr. Surg. 2011, 46, 1516-1522. [CrossRef] [PubMed]

216. Takir, S.; Uydes-Dogan, B.S.; Ozdemir, O. Retina evokes biphasic relaxations in retinal artery unrelated to endothelium, $\mathrm{K}(\mathrm{V}), \mathrm{K}(\mathrm{ATP}), \mathrm{K}(\mathrm{Ca})$ channels and methyl palmitate. Microvasc. Res. 2011, 81, $295-302$. [CrossRef] [PubMed]

217. Dasiewicz, P.J.; Conlon, J.M.; Anderson, W.G. Cardiovascular and vasoconstrictive actions of skate bradykinin in the little skate, Leucoraja erinacea (Elasmobranchii). Gen. Comp. Endocrinol. 2011, 174, 89-96. [CrossRef] [PubMed]

218. Fang, Y.; Nicol, L.; Harouki, N.; Monteil, C.; Wecker, D.; Debunne, M.; Bauer, F.; Lallemand, F.; Richard, V.; Thuillez, C.; et al. Improvement of left ventricular diastolic function induced by $\beta$-blockade: A comparison between nebivolol and metoprolol. J. Mol. Cell. Cardiol. 2011, 51, 168-176. [CrossRef] [PubMed]

219. Wong, W.T.; Ng, C.H.; Tsang, S.Y.; Huang, Y.; Chen, Z.Y. Relative contribution of individual oxidized components in ox-LDL to inhibition on endothelium-dependent relaxation in rat aorta. Nutr. Metab. Cardiovasc. Dis. 2011, 21, 157-164. [CrossRef] [PubMed]

220. Chakkarwar, V.A. Fenofibrate attenuates nicotine-induced vascular endothelial dysfunction in the rat. Vascul. Pharmacol. 2011, 55, 163-168. [CrossRef] [PubMed]

221. Bertinaria, M.; Guglielmo, S.; Rolando, B.; Giorgis, M.; Aragno, C.; Fruttero, R.; Gasco, A.; Parapini, S.; Taramelli, D.; Martins, Y.C.; et al. Amodiaquine analogues containing NO-donor substructures: synthesis and their preliminary evaluation as potential tools in the treatment of cerebral malaria. Eur. J. Med. Chem. 2011, 46, 1757-1767. [CrossRef] [PubMed]

222. Parlar, A.; Can, C.; Erol, A.; Ulker, S. Posttransplantation therapeutic rapamycin concentration protects nitric oxide-related vascular endothelial function: Comparative effects in rat thoracic aorta and coronary endothelial cell culture. Transpl. Proc. 2010, 42, 1923-1930. [CrossRef] [PubMed]

223. Lin, Y.L.; Dai, Z.K.; Lin, R.J.; Chu, K.S.; Chen, I.J.; Wu, J.R.; Wu, B.N. Baicalin, a flavonoid from Scutellaria baicalensis Georgi, activates large-conductance $\mathrm{Ca}^{2+}$-activated $\mathrm{K}^{+}$channels via cyclic nucleotide-dependent protein kinases in mesenteric artery. Phytomedicine 2010, 17, 760-770. [CrossRef] [PubMed]

224. Marrachelli, V.G.; Miranda, F.J.; Centeno, J.M.; Salom, J.B.; Torregrosa, G.; Jover-Mengual, T.; Perez, A.M.; Moro, M.A.; Alborch, E. Role of NO-synthases and cyclooxygenases in the hyperreactivity of male rabbit carotid artery to testosterone under experimental diabetes. Pharmacol. Res. 2010, 61, 62-70. [CrossRef] [PubMed]

225. Novella, S.; Dantas, A.P.; Segarra, G.; Novensa, L.; Bueno, C.; Heras, M.; Hermenegildo, C.; Medina, P. Gathering of aging and estrogen withdrawal in vascular dysfunction of senescent accelerated mice. Exp. Gerontol. 2010, 45, 868-874. [CrossRef] [PubMed]

226. Raffetto, J.D.; Qiao, X.; Beauregard, K.G.; Khalil, R.A. Estrogen receptor-mediated enhancement of venous relaxation in female rat: implications in sex-related differences in varicose veins. J. Vasc. Surg. 2010, 51, 972-981. [CrossRef] [PubMed] 
227. Khoo, N.K.; White, C.R.; Pozzo-Miller, L.; Zhou, F.; Constance, C.; Inoue, T.; Patel, R.P.; Parks, D.A. Dietary flavonoid quercetin stimulates vasorelaxation in aortic vessels. Free Radic. Biol. Med. 2010, 49, 339-347. [CrossRef] [PubMed]

228. Deng, J.; Zhao, R.; Zhang, Z.; Wang, J. Changes in vasoreactivity of rat large- and medium-sized arteries induced by hyperthyroidism. Exp. Toxicol. Pathol. 2010, 62, 317-322. [CrossRef] [PubMed]

229. Seto, S.W.; Lam, T.Y.; Or, P.M.; Lee, W.Y.; Au, A.L.; Poon, C.C.; Li, R.W.; Chan, S.W.; Yeung, J.H.; Leung, G.P.; et al. Folic acid consumption reduces resistin level and restores blunted acetylcholine-induced aortic relaxation in obese/diabetic mice. J. Nutr. Biochem. 2010, 21, 872-880. [CrossRef] [PubMed]

230. Lolli, M.L.; Rolando, B.; Tosco, P.; Chaurasia, S.; di Stilo, A.; Lazzarato, L.; Gorassini, E.; Ferracini, R.; Oliaro-Bosso, S.; Fruttero, R.; et al. Synthesis and preliminary pharmacological characterisation of a new class of nitrogen-containing bisphosphonates (N-BPs). Bioorg. Med. Chem. 2010, 18, 2428-2438. [CrossRef] [PubMed]

231. Marrachelli, V.G.; Miranda, F.J.; Centeno, J.M.; Burguete, M.C.; Castello-Ruiz, M.; Jover-Mengual, T.; Perez, A.M.; Salom, J.B.; Torregrosa, G.; Alborch, E. Mechanisms involved in the relaxant action of testosterone in the renal artery from male normoglycemic and diabetic rabbits. Pharmacol. Res. 2010, 61, 149-156. [CrossRef] [PubMed]

232. Matsumoto, T.; Ishida, K.; Nakayama, N.; Taguchi, K.; Kobayashi, T.; Kamata, K. Mechanisms underlying the losartan treatment-induced improvement in the endothelial dysfunction seen in mesenteric arteries from type 2 diabetic rats. Pharmacol. Res. 2010, 62, 271-281. [CrossRef] [PubMed]

233. Olukman, M.; Orhan, C.E.; Celenk, F.G.; Ulker, S. Apocynin restores endothelial dysfunction in streptozotocin diabetic rats through regulation of nitric oxide synthase and NADPH oxidase expressions. J. Diabetes Complicat. 2010, 24, 415-423. [CrossRef] [PubMed]

234. Yang, H.H.; van Breemen, C.; Chung, A.W. Vasomotor dysfunction in the thoracic aorta of Marfan syndrome is associated with accumulation of oxidative stress. Vascul. Pharmacol. 2010, 52, 37-45. [CrossRef] [PubMed]

235. Liao, W.C.; Hou, M.C.; Wang, G.J.; Yu, K.W.; Lee, F.Y.; Lin, H.C.; Lee, S.D. Sepsis worsening vascular hyporeactivity of the superior mesenteric artery in portal vein-ligated rats. J. Chin. Med. Assoc. 2010, 73, 462-470. [CrossRef]

236. Dominguez, J.M., 2nd; Prisby, R.D.; Muller-Delp, J.M.; Allen, M.R.; Delp, M.D. Increased nitric oxide-mediated vasodilation of bone resistance arteries is associated with increased trabecular bone volume after endurance training in rats. Bone 2010, 46, 813-819. [CrossRef] [PubMed]

237. Li, Y.H.; Xu, Q.; Xu, W.H.; Guo, X.H.; Zhang, S.; Chen, Y.D. Mechanisms of protection against diabetes-induced impairment of endothelium-dependent vasorelaxation by Tanshinone IIA. Biochim. Biophys. Acta 2015, 1850, 813-823. [CrossRef] [PubMed]

238. de Candia, M.; Marini, E.; Zaetta, G.; Cellamare, S.; di Stilo, A.; Altomare, C.D. New organic nitrate-containing benzyloxy isonipecotanilide derivatives with vasodilatory and anti-platelet activity. Eur. J. Pharm. Sci. 2015, 72, 69-80. [CrossRef] [PubMed]

239. Yoon, J.; Park, M.; hyung Lee, J.; Min, B.S.; Ryoo, S. Endothelial nitric oxide synthase activation through obacunone-dependent arginase inhibition restored impaired endothelial function in ApoE-null mice. Vascul. Pharmacol. 2014, 60, 102-109. [CrossRef] [PubMed]

240. Kagota, S.; Maruyama, K.; Wakuda, H.; McGuire, J.J.; Yoshikawa, N.; Nakamura, K.; Shinozuka, K. Disturbance of vasodilation via protease-activated receptor 2 in SHRSP.Z-Lepr fa/IzmDmcr rats with metabolic syndrome. Vascul. Pharmacol. 2014, 63, 46-54. [CrossRef] [PubMed]

241. Kline, L.W.; Karpinski, E. The flavonoid chrysin, an endocrine disrupter, relaxes cholecystokinin- and $\mathrm{KCl}$-induced tension in male guinea pig gallbladder strips through multiple signaling pathways. Steroids 2014, 79, 64-69. [CrossRef] [PubMed]

242. Salomone, S.; Foresti, R.; Villari, A.; Giurdanella, G.; Drago, F.; Bucolo, C. Regulation of vascular tone in rabbit ophthalmic artery: Cross talk of endogenous and exogenous gas mediators. Biochem. Pharmacol. 2014, 92, 661-668. [CrossRef] [PubMed]

243. Liu, L.L.; Yan, L.; Chen, Y.H.; Zeng, G.H.; Zhou, Y.; Chen, H.P.; Peng, W.J.; He, M.; Huang, Q.R. A role for diallyl trisulfide in mitochondrial antioxidative stress contributes to its protective effects against vascular endothelial impairment. Eur. J. Pharmacol. 2014, 725, 23-31. [CrossRef] [PubMed] 
244. Matsumoto, T.; Watanabe, S.; Kawamura, R.; Taguchi, K.; Kobayashi, T. Epigallocatechin gallate attenuates ET-1-induced contraction in carotid artery from type 2 diabetic OLETF rat at chronic stage of disease. Life Sci. 2014, 118, 200-205. [CrossRef] [PubMed]

245. Schrammel, A.; Mussbacher, M.; Wolkart, G.; Stessel, H.; Pail, K.; Winkler, S.; Schweiger, M.; Haemmerle, G.; Al Zoughbi, W.; Hofler, G.; et al. Endothelial dysfunction in adipose triglyceride lipase deficiency. Biochim. Biophys. Acta 2014, 1841, 906-917. [CrossRef] [PubMed]

246. Kivimäki, A.S.; Siltari, A.; Ehlers, P.I.; Korpela, R.; Vapaatalo, H. Lingonberry juice negates the effects of a high salt diet on vascular function and low-grade inflammation. J. Funct. Foods 2014, 7, 238-245. [CrossRef]

247. de Sá, L.Z.M.; Castro, P.F.; Lino, F.M.; Bernardes, M.J.; Viegas, J.C.; Dinis, T.C.; Santana, M.J.; Romao, W.; Vaz, B.G.; Lião, L.M. Antioxidant potential and vasodilatory activity of fermented beverages of jabuticaba berry (Myrciaria jaboticaba). J. Funct. Foods 2014, 8, 169-179. [CrossRef]

248. Zhou, Z.; de Wijs-Meijler, D.; Lankhuizen, I.; Jankowski, J.; Jankowski, V.; Jan Danser, A.H.; Duncker, D.J.; Merkus, D. Blunted coronary vasodilator response to uridine adenosine tetraphosphate in post-infarct remodeled myocardium is due to reduced P1 receptor activation. Pharmacol. Res. 2013, 77, 22-29. [CrossRef] [PubMed]

249. Gadkari, T.V.; Cortes, N.; Madrasi, K.; Tsoukias, N.M.; Joshi, M.S. Agmatine induced NO dependent rat mesenteric artery relaxation and its impairment in salt-sensitive hypertension. Nitric Oxide 2013, 35, 65-71. [CrossRef] [PubMed]

250. Mamo, Y.A.; Angus, J.A.; Ziogas, J.; Soeding, P.F.; Wright, C.E. The role of voltage-operated and non-voltage-operated calcium channels in endothelin-induced vasoconstriction of rat cerebral arteries. Eur. J. Pharmacol. 2014, 742, 65-73. [CrossRef] [PubMed]

251. Hedegaard, E.R.; Nielsen, B.D.; Mogensen, S.; Rembold, C.M.; Frobert, O.; Simonsen, U. Mechanisms involved in increased sensitivity to adenosine $\mathrm{A}(2 \mathrm{~A})$ receptor activation and hypoxia-induced vasodilatation in porcine coronary arteries. Eur. J. Pharmacol. 2014, 723, 216-226. [CrossRef] [PubMed]

252. Chaothanaphat, N.; Dhumma-Upakorn, P.; Jianmongkol, S. In vitro modulating effects of glutathione on vascular tension and involvement of extracellular calcium. Drug Discov. Ther. 2010, 4, 19-25. [PubMed]

253. Rodrigues, G.J.; Cicillini, S.A.; Silva, R.S.; Bendhack, L.M. Mechanisms underlying the vascular relaxation induced by a new nitric oxide generator. Nitric Oxide 2011, 25, 331-337. [CrossRef] [PubMed]

254. Vlasova, M.A.; Tarasova, O.S.; Riikonen, J.; Raula, J.; Lobach, A.S.; Borzykh, A.A.; Smirin, B.V.; Kauppinen, E.I.; Eletskii, A.V.; Herzig, K.H.; et al. Injected nanoparticles: the combination of experimental systems to assess cardiovascular adverse effects. Eur. J. Pharm. Biopharm. 2014, 87, 64-72. [CrossRef] [PubMed]

255. Laspas, P.; Goloborodko, E.; Sniatecki, J.J.; Kordasz, M.L.; Manicam, C.; Wojnowski, L.; Li, H.; Patzak, A.; Pfeiffer, N.; Gericke, A. Role of nitric oxide synthase isoforms for ophthalmic artery reactivity in mice. Exp. Eye Res. 2014, 127, 1-8. [CrossRef] [PubMed]

256. Sakakibara, K.; Feng, G.G.; Li, J.; Akahori, T.; Yasuda, Y.; Nakamura, E.; Hatakeyama, N.; Fujiwara, Y.; Kinoshita, H. Kynurenine causes vasodilation and hypotension induced by activation of KCNQ-encoded voltage-dependent $\mathrm{K}^{+}$channels. J. Pharmacol. Sci. 2015, 129, 31-37. [CrossRef] [PubMed]

257. Zarzuelo, M.J.; Lopez-Sepulveda, R.; Sanchez, M.; Romero, M.; Gomez-Guzman, M.; Ungvary, Z.; Perez-Vizcaino, F.; Jimenez, R.; Duarte, J. SIRT1 inhibits NADPH oxidase activation and protects endothelial function in the rat aorta: Implications for vascular aging. Biochem. Pharmacol. 2013, 85, 1288-1296. [CrossRef] [PubMed]

258. Kurtel, H.; Rodrigues, S.F.; Yilmaz, C.E.; Yildirim, A.; Granger, D.N. Impaired vasomotor function induced by the combination of hypertension and hypercholesterolemia. J. Am. Soc. Hypertens. 2013, 7, 14-23. [CrossRef] [PubMed]

259. Zhao, J.; Suyama, A.; Tanaka, M.; Matsui, T. Ferulic acid enhances the vasorelaxant effect of epigallocatechin gallate in tumor necrosis factor- $\alpha$-induced inflammatory rat aorta. J. Nutr. Biochem. 2014, 25, 807-814. [CrossRef] [PubMed]

260. Kumar, A.; Kumar, A.; Jaggi, A.S.; Singh, N. Efficacy of Cilostazol a selective phosphodiesterase-3 inhibitor in rat model of Streptozotocin diabetes induced vascular dementia. Pharmacol. Biochem. Behav. 2015, 135, 20-30. [CrossRef] [PubMed]

261. Ying, Z.; Xie, X.; Chen, M.; Yi, K.; Rajagopalan, S. $\alpha$-lipoic acid activates eNOS through activation of PI3-kinase/Akt signaling pathway. Vascul. Pharmacol. 2015, 64, 28-35. [CrossRef] [PubMed] 
262. Soloviev, A.; Zholos, A.; Ivanova, I.; Novokhatska, T.; Tishkin, S.; Raevska, A.; Stroyuk, A.; Yefanov, V. Plasmonic gold nanoparticles possess the ability to open potassium channels in rat thoracic aorta smooth muscles in a remote control manner. Vascul. Pharmacol. 2015, 72, 190-196. [CrossRef] [PubMed]

263. Ignarro, L.J.; Buga, G.M.; Wood, K.S.; Byrns, R.E.; Chaudhuri, G. Endothelium-derived relaxing factor produced and released from artery and vein is nitric oxide. Proc. Natl. Acad. Sci. USA 1987, 84, 9265-9269. [CrossRef] [PubMed]

264. Moncada, S.; Korbut, R.; Bunting, S.; Vane, J.R. Prostacyclin is a circulating hormone. Nature 1978, 273, 767-768. [CrossRef] [PubMed]

265. Palmer, R.M.; Ferrige, A.G.; Moncada, S. Nitric oxide release accounts for the biological activity of endothelium-derived relaxing factor. Nature 1987, 327, 524-526. [CrossRef] [PubMed]

266. Wang, R. Hydrogen sulfide: A new EDRF. Kidney Int. 2009, 76, 700-704. [CrossRef] [PubMed]

267. Quillon, A.; Fromy, B.; Debret, R. Endothelium microenvironment sensing leading to nitric oxide mediated vasodilation: A review of nervous and biomechanical signals. Nitric Oxide 2015, 45, 20-26. [CrossRef] [PubMed]

268. Vitecek, J.; Lojek, A.; Valacchi, G.; Kubala, L. Arginine-based inhibitors of nitric oxide synthase: therapeutic potential and challenges. Mediators Inflamm. 2012, 2012, 318087. [CrossRef] [PubMed]

269. Furfine, E.S.; Harmon, M.F.; Paith, J.E.; Knowles, R.G.; Salter, M.; Kiff, R.J.; Duffy, C.; Hazelwood, R.; Oplinger, J.A.; Garvey, E.P. Potent and selective inhibition of human nitric oxide synthases. Selective inhibition of neuronal nitric oxide synthase by S-methyl-L-thiocitrulline and S-ethyl-L-thiocitrulline. J. Biol. Chem. 1994, 269, 26677-26683. [PubMed]

270. Klatt, P.; Schmidt, K.; Brunner, F.; Mayer, B. Inhibitors of brain nitric oxide synthase. Binding kinetics, metabolism, and enzyme inactivation. J. Biol. Chem. 1994, 269, 1674-1680. [PubMed]

271. Balligand, J.L.; Kelly, R.A.; Marsden, P.A.; Smith, T.W.; Michel, T. Control of cardiac muscle cell function by an endogenous nitric oxide signaling system. Proc. Natl. Acad. Sci. USA 1993, 90, 347-351. [CrossRef] [PubMed]

272. Kubes, P.; Suzuki, M.; Granger, D.N. Nitric oxide: An endogenous modulator of leukocyte adhesion. Proc. Natl. Acad. Sci. USA 1991, 88, 4651-4655. [CrossRef] [PubMed]

273. Pfeiffer, S.; Leopold, E.; Schmidt, K.; Brunner, F.; Mayer, B. Inhibition of nitric oxide synthesis by NG-nitro-L-arginine methyl ester (L-NAME): Requirement for bioactivation to the free acid, NG-nitro-L-arginine. Br. J. Pharmacol. 1996, 118, 1433-1440. [CrossRef] [PubMed]

274. Page, C.P.; Curtis, M.J.; Sutter, M. Farmacologia Integrada; Elsevier Espanha: Madrid, Spain, 1998.

275. Suleyman, H.; Demircan, B.; Karagoz, Y. Anti-inflammatory and side effects of cyclooxygenase inhibitors. Pharmacol. Rep. 2007, 59, 247-258. [PubMed]

276. Riendeau, D.; Percival, M.D.; Boyce, S.; Brideau, C.; Charleson, S.; Cromlish, W.; Ethier, D.; Evans, J.; Falgueyret, J.P.; Ford-Hutchinson, A.W.; et al. Biochemical and pharmacological profile of a tetrasubstituted furanone as a highly selective COX-2 inhibitor. Br. J. Pharmacol. 1997, 121, 105-117. [CrossRef] [PubMed]

277. Dannhardt, G.; Kiefer, W. Cyclooxygenase inhibitors-Current status and future prospects. Eur. J. Med. Chem. 2001, 36, 109-126. [CrossRef]

278. Smith, W.L.; DeWitt, D.L.; Garavito, R.M. Cyclooxygenases: Structural, cellular, and molecular biology. Annu. Rev. Biochem. 2000, 69, 145-182. [CrossRef] [PubMed]

279. Mayer, B.; Brunner, F.; Schmidt, K. Inhibition of nitric oxide synthesis by methylene blue. Biochem. Pharmacol. 1993, 45, 367-374. [CrossRef]

280. Kontos, H.A.; Wei, E.P. Hydroxyl radical-dependent inactivation of guanylate cyclase in cerebral arterioles by methylene blue and by LY83583. Stroke 1993, 24, 427-434. [CrossRef] [PubMed]

281. Olson, L.J.; Knych, E.T., Jr.; Herzig, T.C.; Drewett, J.G. Selective guanylyl cyclase inhibitor reverses nitric oxide-induced vasorelaxation. Hypertension 1997, 29, 254-261. [CrossRef] [PubMed]

282. Moro, M.A.; Russel, R.J.; Cellek, S.; Lizasoain, I.; Su, Y.; Darley-Usmar, V.M.; Radomski, M.W.; Moncada, S. cGMP mediates the vascular and platelet actions of nitric oxide: confirmation using an inhibitor of the soluble guanylyl cyclase. Proc. Natl. Acad. Sci. USA 1996, 93, 1480-1485. [CrossRef] [PubMed]

283. Schrammel, A.; Behrends, S.; Schmidt, K.; Koesling, D.; Mayer, B. Characterization of $1 \mathrm{H}-[1,2,4]$ oxadiazolo[4,3-a]quinoxalin-1-one as a heme-site inhibitor of nitric oxide-sensitive guanylyl cyclase. Mol. Pharmacol. 1996, 50, 1-5. [PubMed] 
284. Valtcheva, N.; Nestorov, P.; Beck, A.; Russwurm, M.; Hillenbrand, M.; Weinmeister, P.; Feil, R. The commonly used cGMP-dependent protein kinase type I (cGKI) inhibitor Rp-8-Br-PET-cGMPS can activate cGKI in vitro and in intact cells. J. Biol. Chem. 2009, 284, 556-562. [CrossRef] [PubMed]

285. Baltoumas, F.A.; Theodoropoulou, M.C.; Hamodrakas, S.J. Interactions of the $\alpha$-subunits of heterotrimeric G-proteins with GPCRs, effectors and RGS proteins: A critical review and analysis of interacting surfaces, conformational shifts, structural diversity and electrostatic potentials. J. Struct. Biol. 2013, 182, 209-218. [CrossRef] [PubMed]

286. Weir, M.R.; Dzau, V.J. The renin-angiotensin-aldosterone system: A specific target for hypertension management. Am. J. Hypertens. 1999, 12, 205S-213S. [CrossRef]

287. de Gasparo, M.; Catt, K.J.; Inagami, T.; Wright, J.W.; Unger, T. International union of pharmacology. XXIII. The angiotensin II receptors. Pharmacol. Rev. 2000, 52, 415-472. [PubMed]

288. Jakala, P.; Pere, E.; Lehtinen, R.; Turpeinen, A.; Korpela, R.; Vapaatalo, H. Cardiovascular activity of milk casein-derived tripeptides and plant sterols in spontaneously hypertensive rats. J. Physiol. Pharmacol. 2009, 60, 11-20. [PubMed]

289. Chen, J.; Yildiz, O.; Purdy, R.E. Phenylephrine precontraction increases the sensitivity of rabbit femoral artery to serotonin by enabling 5-HT1-like receptors. J. Cardiovasc. Pharmacol. 2000, 35, 863-870. [CrossRef] [PubMed]

290. Bockaert, J.; Claeysen, S.; Bécamel, C.; Dumuis, A.; Marin, P. Neuronal 5-HT metabotropic receptors: fine-tuning of their structure, signaling, and roles in synaptic modulation. Cell Tissue Res. 2006, 326, 553-572. [CrossRef] [PubMed]

291. Schoeffter, P.; Hoyer, D. 5-Hydroxytryptamine (5-HT)-induced endothelium-dependent relaxation of pig coronary arteries is mediated by 5-HT receptors similar to the 5-HT1D receptor subtype. J. Pharmacol. Exp. Ther. 1990, 252, 387-395. [PubMed]

292. Yildiz, O.; Cicek, S.; Ay, I.; Demirkilic, U.; Tuncer, M. Hypertension increases the contractions to sumatriptan in the human internal mammary artery. Ann. Thorac. Surg. 1996, 62, 1392-1395; discussion 1396. [CrossRef]

293. Kuhr, F.; Lowry, J.; Zhang, Y.; Brovkovych, V.; Skidgel, R.A. Differential regulation of inducible and endothelial nitric oxide synthase by kinin B1 and B2 receptors. Neuropeptides 2010, 44, 145-154. [CrossRef] [PubMed]

294. Leeb-Lundberg, L.M.; Marceau, F.; Muller-Esterl, W.; Pettibone, D.J.; Zuraw, B.L. International union of pharmacology. XLV. Classification of the kinin receptor family: From molecular mechanisms to pathophysiological consequences. Pharmacol. Rev. 2005, 57, 27-77. [CrossRef] [PubMed]

295. Davenport, A.P.; O’Reilly, G.; Molenaar, P.; Maguire, J.J.; Kuc, R.E.; Sharkey, A.; Bacon, C.R.; Ferro, A. Human endothelin receptors characterized using reverse transcriptase-polymerase chain reaction, in situ hybridization, and subtype-selective ligands BQ123 and BQ3020: Evidence for expression of ETB receptors in human vascular smooth muscle. J. Cardiovasc. Pharmacol. 1993, 22, S22-S25. [CrossRef] [PubMed]

296. Levin, E.R. Endothelins. N. Engl. J. Med. 1995, 333, 356-363. [PubMed]

297. Mazzuca, M.Q.; Khalil, R.A. Vascular endothelin receptor type B: Structure, function and dysregulation in vascular disease. Biochem. Pharmacol. 2012, 84, 147-162. [CrossRef] [PubMed]

298. Ogawa, Y.; Nakao, K.; Arai, H.; Nakagawa, O.; Hosoda, K.; Suga, S.; Nakanishi, S.; Imura, H. Molecular cloning of a non-isopeptide-selective human endothelin receptor. Biochem. Biophys. Res. Commun. 1991, 178, 248-255. [CrossRef]

299. Seo, B.; Oemar, B.S.; Siebenmann, R.; Von Segesser, L.; Lüscher, T. Both ETA and ETB receptors mediate contraction to endothelin-1 in human blood vessels. Circulation 1994, 89, 1203-1208. [CrossRef] [PubMed]

300. Caulfield, M.P.; Birdsall, N.J. International Union of Pharmacology. XVII. Classification of muscarinic acetylcholine receptors. Pharmacol. Rev. 1998, 50, 279-290. [PubMed]

301. Chabner, B.; Brunton, L.; Knollman, B. Goodman and Gilman's The Pharmacological Basis of Therapeutics, 20th ed.; McGraw-Hill Education: New York, NY, USA, 2011.

302. Ishii, M.; Kurachi, Y. Muscarinic acetylcholine receptors. Curr. Pharm. Des. 2006, 12, 3573-3581. [CrossRef] [PubMed]

303. Benoist, C.C.; Wright, J.W.; Zhu, M.; Appleyard, S.M.; Wayman, G.A.; Harding, J.W. Facilitation of hippocampal synaptogenesis and spatial memory by C-terminal truncated Nle1-angiotensin IV analogs. J. Pharmacol. Exp. Ther. 2011, 339, 35-44. [CrossRef] [PubMed] 
304. Catt, K.J.; Mendelsohn, F.A.; Millan, M.A.; Aguilera, G. The role of angiotensin II receptors in vascular regulation. J. Cardiovasc. Pharmacol. 1984, 6 (Suppl. 4), S575-S586. [CrossRef] [PubMed]

305. D'Amore, A.; Black, M.J.; Thomas, W.G. The angiotensin II type 2 receptor causes constitutive growth of cardiomyocytes and does not antagonize angiotensin II type 1 receptor-mediated hypertrophy. Hypertension 2005, 46, 1347-1354. [CrossRef] [PubMed]

306. Wright, J.W.; Harding, J.W. Brain renin-angiotensin-A new look at an old system. Prog. Neurobiol. 2011, 95, 49-67. [CrossRef] [PubMed]

307. Wagner, O.F.; Christ, G.; Wojta, J.; Vierhapper, H.; Parzer, S.; Nowotny, P.J.; Schneider, B.; Waldhausl, W.; Binder, B.R. Polar secretion of endothelin-1 by cultured endothelial cells. J. Biol. Chem. 1992, 267, 16066-16068. [PubMed]

308. Cocks, T.M.; Angus, J.A. Endothelium-dependent relaxation of coronary arteries by noradrenaline and serotonin. Nature 1983, 305, 627-630. [CrossRef] [PubMed]

309. He, G.W.; Yang, C.Q. Effect of thromboxane A2 antagonist GR32191B on prostanoid and nonprostanoid receptors in the human internal mammary artery. J. Cardiovasc. Pharmacol. 1995, 26, 13-19. [CrossRef] [PubMed]

310. Leemhuis, J.; Boutillier, S.; Schmidt, G.; Meyer, D.K. The protein kinase A inhibitor H89 acts on cell morphology by inhibiting Rho kinase. J. Pharmacol. Exp. Ther. 2002, 300, 1000-1007. [CrossRef] [PubMed]

311. Petersen, R.K.; Madsen, L.; Pedersen, L.M.; Hallenborg, P.; Hagland, H.; Viste, K.; Doskeland, S.O.; Kristiansen, K. Cyclic AMP (cAMP)-mediated stimulation of adipocyte differentiation requires the synergistic action of Epac- and cAMP-dependent protein kinase-dependent processes. Mol. Cell. Biol. 2008, 28, 3804-3816. [CrossRef] [PubMed]

312. Emery, A.C.; Eiden, M.V.; Eiden, L.E. A new site and mechanism of action for the widely used adenylate cyclase inhibitor SQ22,536. Mol. Pharmacol. 2013, 83, 95-105. [CrossRef] [PubMed]

313. Bouschet, T.; Perez, V.; Fernandez, C.; Bockaert, J.; Eychene, A.; Journot, L. Stimulation of the ERK pathway by GTP-loaded Rap1 requires the concomitant activation of Ras, protein kinase C, and protein kinase A in neuronal cells. J. Biol. Chem. 2003, 278, 4778-4785. [CrossRef] [PubMed]

314. Yuan, W.; Bers, D.M. Protein kinase inhibitor H-89 reverses forskolin stimulation of cardiac L-type calcium current. Am. J. Physiol. 1995, 268, C651-C659. [PubMed]

315. Satake, N.; Fujimoto, S.; Shibata, S. The potentiation of nitroglycerin-induced relaxation by PKG inhibition in rat aortic rings. Gen. Pharmacol. 1996, 27, 701-705. [CrossRef]

316. Buch, J.G. Clinically Oriented Pharmacology; Version 2; PDU Medical College: Rajkot, Gujarat, India, 2010.

317. Walch, L.; Gascard, J.P.; Dulmet, E.; Brink, C.; Norel, X. Evidence for a $\mathrm{M}_{1}$ muscarinic receptor on the endothelium of human pulmonary veins. Br. J. Pharmacol. 2000, 130, 73-78. [CrossRef] [PubMed]

318. Bhattacharjee, A.K.; Pomponio, J.W.; Evans, S.A.; Pervitsky, D.; Gordon, R.K. Discovery of subtype selective muscarinic receptor antagonists as alternatives to atropine using in silico pharmacophore modeling and virtual screening methods. Bioorg. Med. Chem. 2013, 21, 2651-2662. [CrossRef] [PubMed]

319. Zholos, A.V.; Bolton, T.B. Muscarinic receptor subtypes controlling the cationic current in guinea-pig ileal smooth muscle. Br. J. Pharmacol. 1997, 122, 885-893. [CrossRef] [PubMed]

320. Archer, S.L.; Rusch, N.J. Potassium Channels in Cardiovascular Biology; Springer: New York, NY, USA, 2001.

321. Burnham, M.P.; Bychkov, R.; Feletou, M.; Richards, G.R.; Vanhoutte, P.M.; Weston, A.H.; Edwards, G. Characterization of an apamin-sensitive small-conductance $\mathrm{Ca}^{2+}$-activated $\mathrm{K}^{+}$channel in porcine coronary artery endothelium: Relevance to EDHF. Br. J. Pharmacol. 2002, 135, 1133-1143. [CrossRef] [PubMed]

322. Bychkov, R.; Burnham, M.P.; Richards, G.R.; Edwards, G.; Weston, A.H.; Feletou, M.; Vanhoutte, P.M. Characterization of a charybdotoxin-sensitive intermediate conductance $\mathrm{Ca}^{2+}$-activated $\mathrm{K}^{+}$channel in porcine coronary endothelium: relevance to EDHF. Br. J. Pharmacol. 2002, 137, 1346-1354. [CrossRef] [PubMed]

323. Feletou, M.; Vanhoutte, P. EDHF: The Complete Story; CRC Press: Hoboken, NJ, USA, 2005.

324. Frieden, M.; Sollini, M.; Beny, J. Substance P and bradykinin activate different types of $\mathrm{K}_{\mathrm{Ca}}$ currents to hyperpolarize cultured porcine coronary artery endothelial cells. J. Physiol. 1999, 519, 361-371. [CrossRef] [PubMed]

325. Marchenko, S.M.; Sage, S.O. Calcium-activated potassium channels in the endothelium of intact rat aorta. J. Physiol. 1996, 492, 53-60. [CrossRef] [PubMed] 
326. Taylor, M.S.; Bonev, A.D.; Gross, T.P.; Eckman, D.M.; Brayden, J.E.; Bond, C.T.; Adelman, J.P.; Nelson, M.T. Altered expression of small-conductance $\mathrm{Ca}^{2+}$-activated $\mathrm{K}^{+}(\mathrm{SK} 3)$ channels modulates arterial tone and blood pressure. Circ. Res. 2003, 93, 124-131. [CrossRef] [PubMed]

327. Hille, B. The selective inhibition of delayed potassium currents in nerve by tetraethylammonium ion. J. Gen. Physiol. 1967, 50, 1287-1302. [CrossRef] [PubMed]

328. Schumacher, M.A.; Rivard, A.F.; Bachinger, H.P.; Adelman, J.P. Structure of the gating domain of a $\mathrm{Ca}^{2+}$-activated $\mathrm{K}^{+}$channel complexed with $\mathrm{Ca}^{2+} /$ calmodulin. Nature 2001, 410, 1120-1124. [CrossRef] [PubMed]

329. Boyd, A.E., 3rd; Aguilar-Bryan, L.; Nelson, D.A. Molecular mechanisms of action of glyburide on the $\beta$ cell. Am. J. Med. 1990, 89, 3S-10S. [CrossRef]

330. Standen, N.B.; Quayle, J.M.; Davies, N.W.; Brayden, J.E.; Huang, Y.; Nelson, M.T. Hyperpolarizing vasodilators activate ATP-sensitive $\mathrm{K}^{+}$channels in arterial smooth muscle. Science 1989, 245, 177-180. [CrossRef] [PubMed]

331. Katsuda, Y.; Egashira, K.; Ueno, H.; Akatsuka, Y.; Narishige, T.; Arai, Y.; Takayanagi, T.; Shimokawa, H.; Takeshita, A. Glibenclamide, a selective inhibitor of ATP-sensitive $\mathrm{K}^{+}$channels, attenuates metabolic coronary vasodilatation induced by pacing tachycardia in dogs. Circulation 1995, 92, 511-517. [CrossRef] [PubMed]

332. Chandy, K.G.; Wulff, H.; Beeton, C.; Pennington, M.; Gutman, G.A.; Cahalan, M.D. $\mathrm{K}^{+}$channels as targets for specific immunomodulation. Trends Pharmacol. Sci. 2004, 25, 280-289. [CrossRef] [PubMed]

333. Feske, S.; Gwack, Y.; Prakriya, M.; Srikanth, S.; Puppel, S.H.; Tanasa, B.; Hogan, P.G.; Lewis, R.S.; Daly, M.; Rao, A. A mutation in Orai1 causes immune deficiency by abrogating CRAC channel function. Nature 2006, 441, 179-185. [CrossRef] [PubMed]

334. Wellman, G.C.; Bevan, J.A. Barium inhibits the endothelium-dependent component of flow but not acetylcholine-induced relaxation in isolated rabbit cerebral arteries. J. Pharmacol. Exp. Ther. 1995, 274, 47-53. [PubMed]

335. Golan, D.E.; Tashjian, A.H.; Armstrong, E.J. Principles of Pharmacology: The Pathophysiologic Basis of Drug Therapy; Wolters Kluwer Health: Philadelphia, PA, USA, 2011.

336. Furberg, C.D.; Psaty, B.M.; Meyer, J.V. Nifedipine. Dose-related increase in mortality in patients with coronary heart disease. Circulation 1995, 92, 1326-1331. [CrossRef] [PubMed]

337. Ma, H.T.; Venkatachalam, K.; Parys, J.B.; Gill, D.L. Modification of store-operated channel coupling and inositol trisphosphate receptor function by 2-aminoethoxydiphenyl borate in DT40 lymphocytes. J. Biol. Chem. 2002, 277, 6915-6922. [CrossRef] [PubMed]

338. Prakriya, M.; Lewis, R.S. Potentiation and inhibition of $\mathrm{Ca}^{2+}$ release-activated $\mathrm{Ca}^{2+}$ channels by 2-aminoethyldiphenyl borate (2-APB) occurs independently of IP3 receptors. J. Physiol. 2001, 536, 3-19. [CrossRef] [PubMed]

339. Bootman, M.D.; Collins, T.J.; MacKenzie, L.; Roderick, H.L.; Berridge, M.J.; Peppiatt, C.M. 2-aminoethoxydiphenyl borate (2-APB) is a reliable blocker of store-operated $\mathrm{Ca}^{2+}$ entry but an inconsistent inhibitor of InsP3-induced $\mathrm{Ca}^{2+}$ release. FASEB J. 2002, 16, 1145-1150. [CrossRef] [PubMed]

340. Adding, L.C.; Bannenberg, G.L.; Gustafsson, L.E. Basic experimental studies and clinical aspects of gadolinium salts and chelates. Cardiovasc. Drug Rev. 2001, 19, 41-56. [CrossRef] [PubMed]

341. Fellner, S.K.; Arendshorst, W.J. Store-operated $\mathrm{Ca}^{2+}$ entry is exaggerated in fresh preglomerular vascular smooth muscle cells of SHR. Kidney Int. 2002, 61, 2132-2141. [CrossRef] [PubMed]

342. Rogers, T.B.; Inesi, G.; Wade, R.; Lederer, W. Use of thapsigargin to study $\mathrm{Ca}^{2+}$ homeostasis in cardiac cells. Biosci. Rep. 1995, 15, 341-349. [CrossRef] [PubMed]

(C) 2016 by the authors; licensee MDPI, Basel, Switzerland. This article is an open access article distributed under the terms and conditions of the Creative Commons Attribution (CC-BY) license (http://creativecommons.org/licenses/by/4.0/). 